TA7

W34m

no.

EL-91-5

c. 2

Corps neers
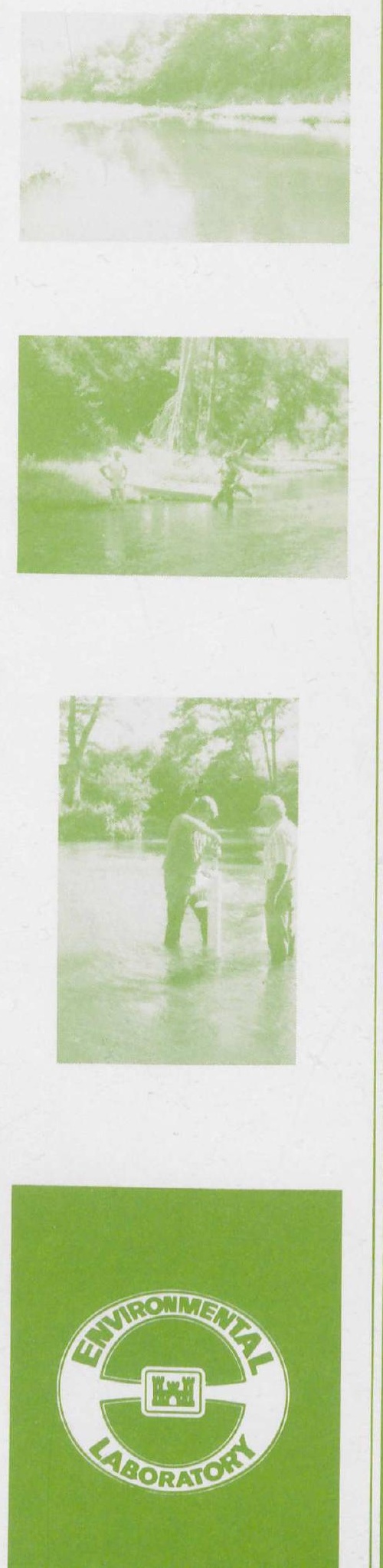

\title{
MACROINVERTEBRATES OF LUXAPALILA CREEK, MISSISSIPPI AND ALABAMA, 1987-89
}

by

Barry S. Payne, Andrew C. Miller, Christina Miller-Way, C. Rex Bingham

Environmental Laboratory

DEPARTMENT OF THE ARMY

Waterways Experiment Station, Corps of Engineers

3909 Halls Ferry Road, Vicksburg, Mississippi 39180-6199

\section{US-CE-C PROPERT OF THE UNITED STATES GOVERNMENT}

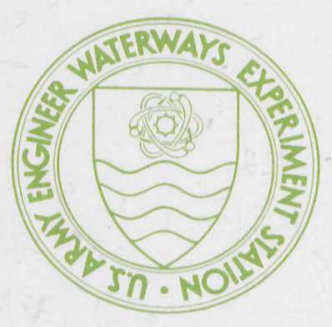

February 1991

Final Report

Approved For Public Release; Distribution Unlimited

\author{
RESEARCH LIBRARY \\ US ARMY ENGINEER WATERWAYS \\ EXPERIMENT STATION \\ VICKSBURG, MISSISSIPPI
}


Destroy this report when no longer needed. Do not return it to the originator.

The findings in this report are not to be construed as an official

Department of the Army position unless so designated by other authorized documents.

The contents of this report are not to be used for advertising, publication, or promotional purposes. Citation of trade names does not constitute an official endorsement or approval of the use of such commercial products. 


\section{9,338494}

\section{REPORT DOCUMENTATION PAGE}

Public reporting burden for this collection of information is estimated to average 1 hour per response, including the time for reviewing instructions, searching existing data sources. gathering and

Davis Highway, Suite 1204, Arlington, VA 22202-4302, and to the Office of Management and Budget, Paperwork Reduction Project (0704-0 188). Washington, OC 20503.

\begin{tabular}{l|l|l|} 
1. AGENCY USE ONLY (Leave blank) & $\begin{array}{l}\text { 2. REPORT DATE } \\
\text { February 1991 }\end{array}$ & $\begin{array}{l}\text { 3. REPORT TYPE AND DATES COVERED } \\
\text { Fina1 report }\end{array}$ \\
\hline
\end{tabular}

4. TITLE AND SUBTITLE

5. FUNDING NUMBERS

Macroinvertebrates of Luxapalila Creek, Mississippi and Alabama, 1987-89

6. AUTHOR(S)

Barry S. Payne, Andrew C. Miller, Christina Miller-Way, C. Rex Bingham

7. PERFORMING ORGANIZATION NAME(S) AND ADDRESS(ES)

8. PERFORMING ORGANIZATION REPORT NUMBER

USAE Waterways Experiment Station, Environmental

Laboratory, 3909 Halls Ferry Road, Vicksburg, MS 39180-6199

9. SPONSORING/MONITORING AGENCY NAME(S) AND ADDRESS(ES)

iscellaneous

Paper EL-91-5

10. SPONSORING/MONITORING

AGENCY REPORT NUMBER

US Army Engineer District, Mobile

Mobile, AL 36628-0001

\section{SUPPLEMENTARY NOTES}

Available from National Technical Information Service, 5285 Port Royal

Road, Springfield, VA 22161

12a. DISTRIBUTION/AVAILABILITY STATEMENT

12b. DISTRIBUTION CODE .

Approved for public release; distribution unlimited

\section{ABSTRACT (Maximum 200 words)}

A survey of the macroinvertebrate community of four pools and four riffles in Luxapalila Creek, Mississippi and Alabama, was conducted in 1987-89. The purpose was to collect preconstruction data before the creek is impacted by selective clearing and snagging, bank protection, construction of notched sills, and a fabric dam. Luxapalila Creek can be characterized as exhibiting high macroinvertebrate species richness, diversity, and equitable distribution of chironomid (midge) larvae and oligochaete (worm) species. These two groups dominated the fauna and comprised 77 and 62 percent of the macroinvertebrates in pools and riffles, respectively. Total macroinvertebrate density was lower although more stable in pools $(6,433-7,229$ individuals/sq $\mathrm{m}$ ) than in riffles where it was higher and more variable $(9,662-28,820$ individuals/sq $\mathrm{m})$. Species richness of chironomids appeared to be greater in pools than riffles probably because of drift out of riffles and into pools. High winter discharge led to greatly reduced macroinvertebrate densities in all riffles and in two pools

\begin{tabular}{l}
\hline 14. SUBJECT TERMS \\
Invertebrates \\
Stream ecology \\
\begin{tabular}{ll}
\hline 17. SECURITY CLASSIFICATION & 18. SECURITY CLASSIFICATION \\
OF REPORT & OF THIS PAGE \\
UNCLASSIFIED & UNCLASSIFIED \\
\hline
\end{tabular}
\end{tabular}

NSN 7540-01-280-5500

(Continued)

\begin{tabular}{|l|l|}
\hline & $\begin{array}{c}\text { 15. NUMBER OF PAGES } \\
89\end{array}$ \\
\cline { 2 - 2 } & 16. PRICE CODE \\
\hline $\begin{array}{l}\text { 19. SECUAITY CLASSIFICATION } \\
\text { OF ABSTRACT }\end{array}$ & 20. LIMITATION OF ABSTRACT \\
\hline
\end{tabular}


13. (Concluded).

during the spring of 1989. Post-construction biological monitoring will determine if community composition and total density is affected by proposed channel modifications. 
In September 1987, the US Army Engineer Waterways Experiment Station (WES) initiated invertebrate studies on Luxapalila Creek, Mississippi and Alabama, for the US Army Corps of Engineers, Mobile District (CESAM). The purpose was to collect baseline information on invertebrates to evaluate the effects of proposed channel modifications.

This report was prepared by Dr. Barry S. Payne, Dr. Andrew C. Miller, Ms. Christina Miller-Way, and Mr. C. Rex Bingham, all of the Aquatic Habitat Group (AHG), WES. Mr. Edwin Theriot was Chief, AHG, Dr. Conrad J. Kirby was Chief, Environmental Resources Division, and Dr. John Harrison was Chief, Environmental Laboratory, WES, during preparation of this report. Mr. Brian Peck, CESAM, monitored the study and reviewed an early draft of the report. The report was edited by Ms. Janean C. Shirley of the WES Information Products Division, Information Technology Laboratory.

Commander and Director of WES was COL Larry B. Fulton, EN. Technical Director was Dr. Robert W. Whalin.

This report should be cited as follows:

Payne, B. S., Miller, A. C., Miller-Way, C., and Bingham, C. R. 1991. "Macroinvertebrates of Luxapalila Creek, Mississippi and Alabama, 1987-89," Miscellaneous Paper EL-91-5. US Army Engineer Waterways Experiment Station, Vicksburg, MS. 
PREFACE . . . . . . . . . . . . . . . . . . . . . . . . . . . . . . . . 1

CONVERSION FACTORS, NON-SI TO SI (METRIC) UNITS, OF MEASUREMENT . . . . 3

PART I: INTRODUCTION . . . . . . . . . . . . . . . . . . . . 4

Background . . . . . . . . . . . . . . . . . . . . 4

Purpose and Scope. . . . . . . . . . . . . . . . . . . . . . 4

PART II: STUDY AREA AND METHODS . . . . . . . . . . . . . . . . . . . 5

Study Area . . . . . . . . . . . . . . . . . . . . . . . 5

Methods............................ . . . . . . . . 7

PART III: RESULTS . . . . . . . . . . . . . . . . . . . . . . 9

Physicochemical Conditions . . . . . . . . . . . . . . . 9

Biological Conditions . . . . . . . . . . . . . . . . . . . . . 14

PART IV: DISCUSSION . . . . . . . . . . . . . . . . . . . 27

Major Findings . . . . . . . . . . . . . . . . . . . . 27

Recommendations . . . . . . . . . . . . . . . . . . . . . . . 28

REFERENCES . . . . . . . . . . . . . . . . . . . . . . . . . . . . . . 30

APPENDIX A: COUNTS OF MAJOR TAXA PER CORE SAMPLE, FALL 1987 . . . . . A1

APPENDIX B: SPECIES COMPOSITION IN BENTHIC SAMPLES COLLECTED

IN THE SPRING OF 1988 . . . . . . . . . . . . . . . . . . . . B B

APPENDIX C: COUNTS OF MAJOR TAXA PER CORE SAMPLE, FALL, 1988 . . . . . C1

APPENDIX D: SPECIES COMPOSITION IN SPRING, 1989 SAMPLES . . . . . . . D1

APPENDIX E: COUNTS OF MAJOR TAXA, PER CORE SAMPLE, COLLECTED

FROM SITE 4 IN THE FALL OF 1989 . . . . . . . . . . . . . E1 


\section{CONVERSION FACTORS, NON-SI TO SI (METRIC) \\ UNITS OF MEASUREMENT}

Non-SI units of measurement used in this report can be converted to SI (metric) units as follows:

Multiply

cubic feet per second

feet

gallons (US liquid)

inches

miles (US statute)

square miles
By

0.02831685

0.3048

3.785412

2.54

1.609347

2.589998
To Obtain

cubic metres per second metres

cubic decimetres

centimetres

kilometres

square kilometres 


\section{MACROINVERTEBRATES OF LUXAPALILA CREEK, MISSISSIPPI AND ALABAMA, 1987-89}

\section{PART I: INTRODUCTION}

\section{Background}

1. The US Army Corps of Engineers, Mobile District (CESAM) is preparing a flood control plan for Luxapalila Creek, Mississippi and Alabama. The project area includes the lower reach of the creek, from its mouth to river mile (RM) 25.5. The current plan calls for selective clearing and snagging, bank protection, and construction of notched sills, excavation of pools, and a fabric dam. Proposed channel modifications would protect rural areas upstream of Columbus, MS, against floods expected to occur every 1.5 years, and urban areas within columbus would be protected against floods expected every 5 years.

2. Many aquatic habitats are altered by channel diversion, modification, or construction of dams (Standford and Ward 1979). This demand on 1otic habitats has brought about an interest in habitat improvement or development to mitigate losses caused by man's activities. For example, the fabric dam and other modifications proposed for Luxapalila Creek would help to provide access to the upper watershed by walleye for 45 percent of their critical spawning migration period (US Fish and Wildlife Service 1987). A wide array of measures, including construction of sills, artificial riffles, ponds, and planting of riparian vegetation, have been used to improve habitat for aquatic biota in streams throughout the United States (Shields 1983; Woods and Griswold 1981; US Soil Conservation Service 1971a, 1971b; King, Miller, and Glover 1982; Miller 1987.

\section{Purpose and Scope}

3. The purpose of this study was to obtain baseline data on sediment characteristics and benthic invertebrates at Luxapalila Creek, Mississippi and Alabama. This information will be used by CESAM to evaluate the effects of proposed channel alterations and mitigation measures on selected reaches of the creek. 


\section{PART II: STUDY AREA AND METHODS}

\section{Study Area}

4. Luxapalila Creek is located in northeast Mississippi and northwest Alabama (Figure 1). The creek originates in southern Marion County near Winfield, $A L$ and flows in a southerly and then a southwestern direction for about 75 miles* before joining the Tombigbee River at RM 362.35. The drainage basin includes 794.5 square miles of mainly forested and agricultural land that is relatively unaffected by urban development. Riparian vegetation consists of bald cypress (Taxodium distichum), river birch (Betula nigrum), maples (Acer spp.) and oaks (Quercus spp.).

5. The study area included approximately 30 miles of Luxapalila Creek in Lowndes County, Mississippi, and Lamar County, Alabama. In this reach the creek consists of riffles, runs, and short pools. Most pools are narrow, comparatively shallow, and appear to function more like runs than pools. Substrate in the riffles consists of gravelly sand with very little cobble or bedrock. A 26-mile segment of the creek between Winfield, AL and the AlabamaMississippi State line was channelized in 1922. In 1967 the lower 2.1 miles of Luxapalila Creek was channelized (Arner et al. 1976; US Army Corps of Engineers 1986; US Fish and Wildlife Service 1987).

6. Luxapalila Creek is near the northern edge of the Gulf Coastal Plains Physiographic Province. The topography is hilly and ranges from low, smoothly rounded hills of 40-50 ft relief within broad intervening valleys to hills and ridges up to $200 \mathrm{ft}$ high separated by narrow valleys with steeply sloping sides. The basin has a temperate climate characterized by long, warm summers, and short, usually mild winters. The basin receives abundant rainfall that is fairly well distributed throughout the year. Annual rainfall at Columbus from 1951 to 1980 was 56.75 in.

7. Four sampling sites, each consisting of a single pool and a nearby riffle, were located on Luxapalila Creek. Sites 1-3 were within the reach to be modified by proposed channel alterations. Site 4, which is in a previously channelized reach, was upstream of proposed channel modifications. The following is a brief description of the four sites surveyed. More detailed data

* A table of factors for converting non-SI to SI (metric) units is presented on page 3 . 
on sediments and water chemistry at each site can be found in Part III of this report.

Site 1

8. At the site closest to the mouth of the creek (Figure 1) the channel was braided and approximately $80 \mathrm{ft}$ wide. Substrate in the riffle consisted of firm gravel over hardpan clay. There was no submersed vegetation present, although the emergent macrophyte water willow (Justicia americana) had colonized gravelly shoals along the left descending bank.

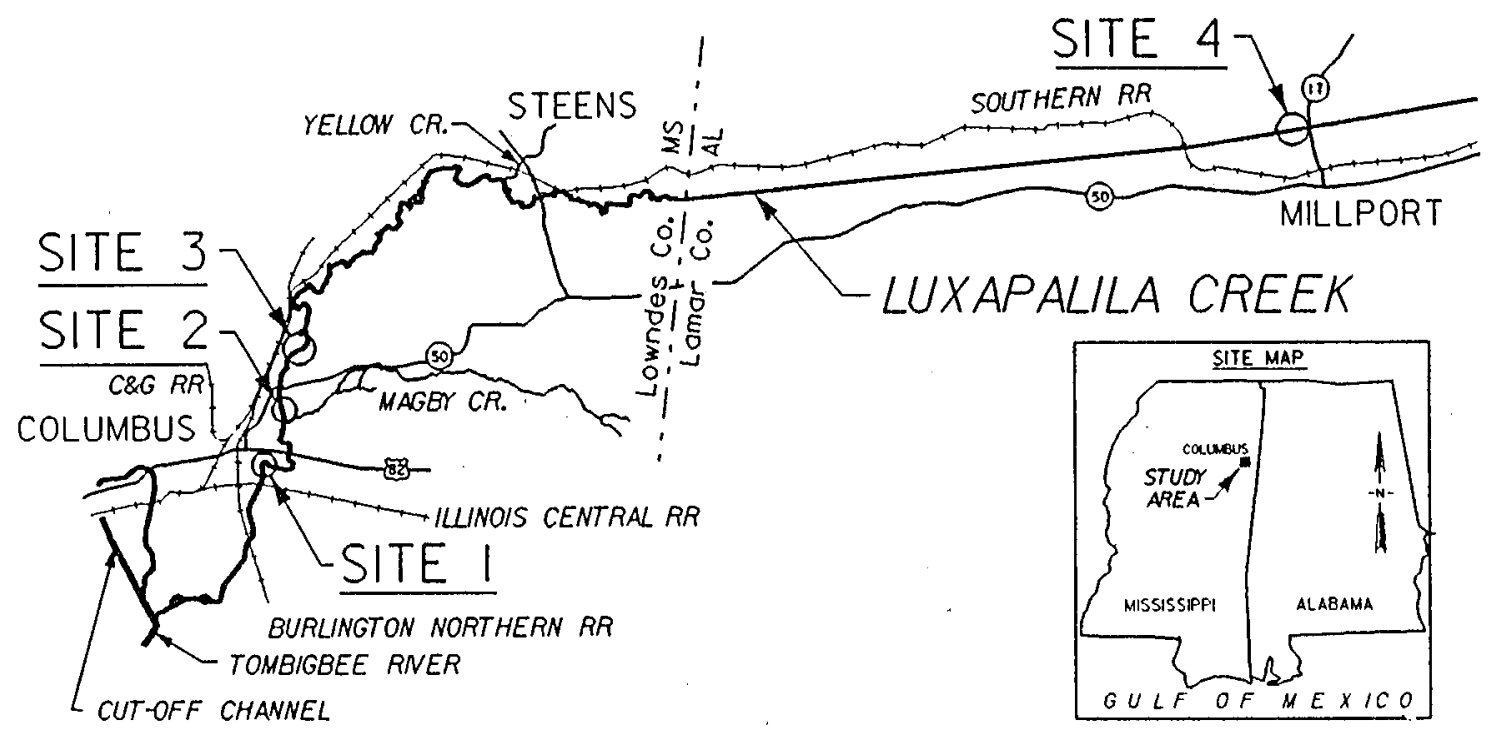

Figure 1. Study sites on Luxapalila Creek, Mississippi and Alabama

9. The pool at site 1 was located approximately $500 \mathrm{ft}$ upriver of the riffle. Approximately 20 percent of the substrate in the lower reach of the pool, where samples were taken, was stabilized by logs or other large snags. Substrate consisted of sand overlain by a 2-in. layer of pea gravel. Canopy coverage was approximately 20 percent and there was no submersed or emergent vegetation in the pool.

Site 2

10. The riffle at site 2 was approximately $50 \mathrm{ft}$ wide and was bordered by extensive stands of $J$. americana. The gravel was colonized by scattered clusters of Sparganium: sp. covered by an unidentified algae. The riparian canopy was open.

11. The pool, which was located approximately $100 \mathrm{ft}$ downstream, was approximately $100 \mathrm{ft}$ wide. Substrate consisted primarily of sand and silt overlain by a layer of leaf litter and twigs. Snags were present in the pool, but to a lesser extent than at site 1 . No emergent or submersed vegetation 
was observed. The riparian cover, which consisted of $T$. distichum and water oak (Quercus nigra), covered approximately 50 percent of the channel. Banks were low, 3-4 ft high, and stable.

Site 3

12. The riffle at site 3 was about $50 \mathrm{ft}$ wide, and exposed gravel bars were colonized by $J$. americana. Substrate consisted mainly of gravel that appeared to be slightly less consolidated than in the riffle at site 2 but more consolidated than gravel at site 1 . There were no snags in the channel and no riparian cover.

13. The pool was located approximately 1,500 ft downstream of the riffle and $500 \mathrm{ft}$ upstream of a US Geological Survey (USGS) discharge gage (No. 02443500 near Columbus, MS). No submersed vegetation was present and the riparian vegetation did not form a noticeable canopy. Justicia americana was present along the border of the pool, but to a lesser extent than in the riffle.

Site 4

14. This site, which was located in Alabama, was approximately 20 miles upstream of site 3 ; this river reach experienced considerably lower average discharge than the lower reach. This reach was straight (the result of channel straightening, in the $1920^{\prime} \mathrm{s}$, Figure 1), less than $50 \mathrm{ft}$ wide, with a. nearly closed canopy consisting of oaks (Quercus spp.), maples (Acer spp.), sweetgum (Liquidambar styraciflua), and sycamore (Platanus occidentalis). River banks were 8-10 ft high and many trees along the bank were undercut by erosion.

15. Meanders had begun to form within the channelized reach at site 4. The riffle was less than $2 \mathrm{ft}$ deep where samples were taken. There were no exposed gravel bars or emergent vegetation. The pool was located approximately $500 \mathrm{ft}$ downstream of the riffle and had been created by woody snags.

\section{Methods}

16. Macroinvertebrates were collected in September, 1987, June and September 1988, and June and October, 1989. Sites 1-3 were sampled from the beginning of the survey through June 1989; site 4 was first sampled in June 1988 and the final sample was taken in October, 1989. Therefore, four consecutive samples were taken at each site; two in the spring and two in the fall. A decision was made by CESAM to add site 4 after the main sampling program had 
begun. Counts of major taxa and species composition for each of the sampling periods are presented in Appendixes A-E.

17. At each site, 13 sediment samples were collected from each pool and each riffle. Ten samples were taken for macroinvertebrates, one for total organic content, and two (that were later combined) for grain size analysis. All samples were obtained with a hand-held coring device (Miller and Bingham 1987) that penetrated to a depth of $10 \mathrm{~cm}$ and sampled $0.0079 \mathrm{sq} \mathrm{m}$. Organic content was determined by first drying the sample at $65^{\circ} \mathrm{C}$, weighing, then heating in a muffle furnace to $550^{\circ} \mathrm{C}$. The weight after firing at this latter temperature is termed "ash-free dry weight" and is the loss due to volatilization of organic material. Grain size was determined by sieving the sediments through a standard set of USGS sieves, and weighing each fraction. Sediment samples obtained for macroinvertebrates were preserved in the field with buffered 10-percent Formalin that was stained with rose bengal to facilitate removal of organisms.

18. In the laboratory benthic invertebrates were removed from sediments by an elutriation process. Sediment samples were agitated (swirled in a 3-gal bucket and poured through a 500- $\mu$ mesh sieve. Lighter material (detritus and invertebrates) was poured out of the bucket, sand and gravel remained on the screen, and fine, silt passed through the screen. Each sample was elutriated five times; lighter material was combined and sand and gravel were discarded. Tests have indicated that this process retrieves 90-100 percent of the invertebrates on sand and gravel substrate.

19. Invertebrates were picked from the elutriated sample with the aid of a binocular microscope. Organisms were first sorted to major group (chironomids, oligochaetes, ephemeropterans, etc.) and counted. Following this initial analysis, chironomids, oligochaetes, and other invertebrates were identified to the lowest possible taxon with appropriate keys. Voucher specimens have been retained at the US Army Engineer Waterways Experiment Station (WES). A complete listing of invertebrates found at each sampling site appears in Appendix A. 


\section{PART III: RESULTS}

\section{Physicochemical Conditions}

\section{Discharge}

20. The mean daily discharge for Luxapalila Creek at Columbus, MS (16 years of record; Tharpe et a1. 1987) is 1,130 cfs but varies greatly from winter and spring maxima to summer and fall minima ( $F$-gure 2a). Mean daily discharge was usually greater than 1,000 cfs in winter and spring and often ranged up to 6,000 cfs. During the 16 -year period of record the maximum daily discharge was 40,400 cfs on 14 April, 1979. Mean daily discharge was low (<500 cfs and often 50 to $200 \mathrm{cfs}$ ) between June and August; the minimum discharge reported by Tharpe et al. 1987) occurred during the present study and was $20 \mathrm{cfs}$ on 19 August, 1988.

21. Mean daily discharge during the winter (1986-87) prior to this study was near average (Figure $2 \mathrm{~b}$ ). Winter and spring discharge in 1987-88 was low; values less than $1,000 \mathrm{cfs}$ were typical and no values greater than $3,000 \mathrm{cfs}$ occurred. In contrast, the winter and spring of 1988-89 were characterized by higher than average daily discharge; during this period a maximum value of nearly $17,000 \mathrm{cfs}$ was recorded (i.e., approximately three times. higher than the average maximum value; compare Figures $2 a$ and $2 b$ ). The mean daily discharges for dates sampled during this survey are given below:

\begin{tabular}{lc} 
Sampling Date & Mean, cfs \\
\hline 16 September 1987 & 102 \\
27 June 1988 & 40 \\
28 June 1988 & 37 \\
10 October 1988 & 216 \\
11 October 1988 & 177 \\
31 May 1989 & 239 \\
1 June 1989 & 217 \\
2 November 1989 & 194
\end{tabular}

22. The present study included samples affected by a wide range of hydrologic conditions. The samples collected in the fall of 1987 were taken during a low-water period after a winter and spring characterized by high water. Samples collected in 1988 were taken during a sustained drought after extremely low water during the previous winter and spring. The June 1989 samples were collected after high discharge that occurred during the winter and spring of 1988-89. 


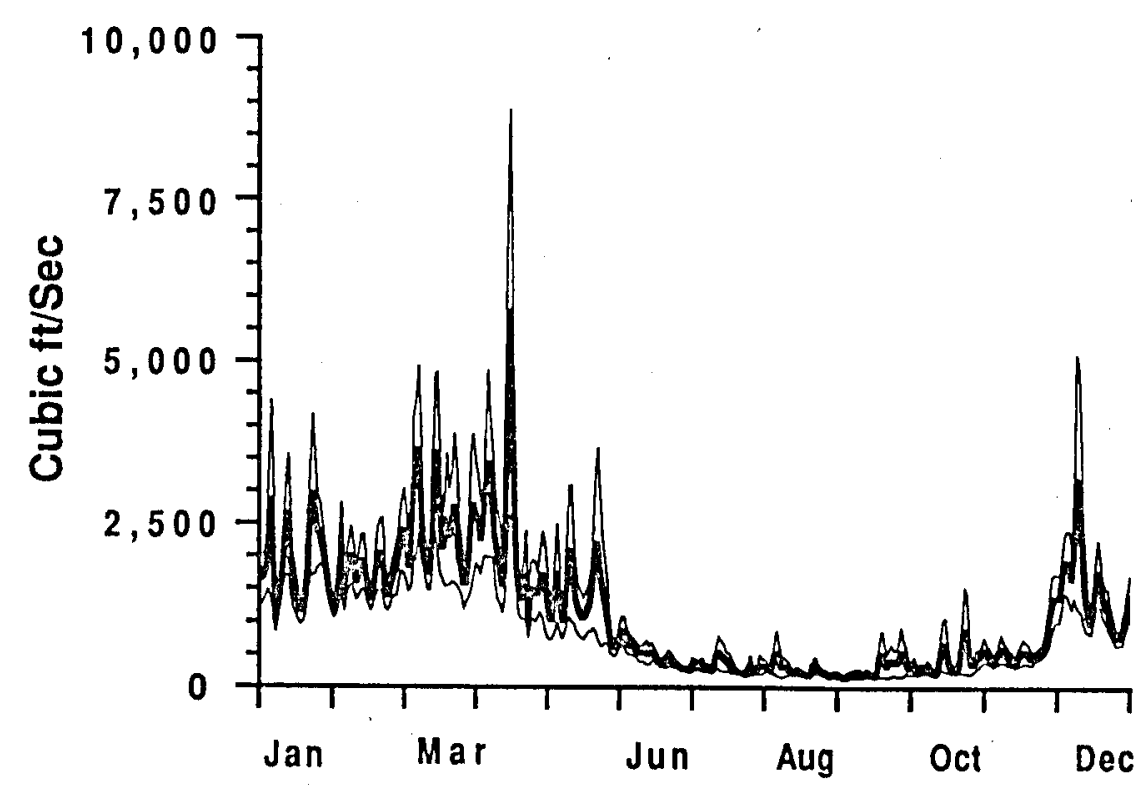

a. Average daily discharge \pm standard error, 1974-88

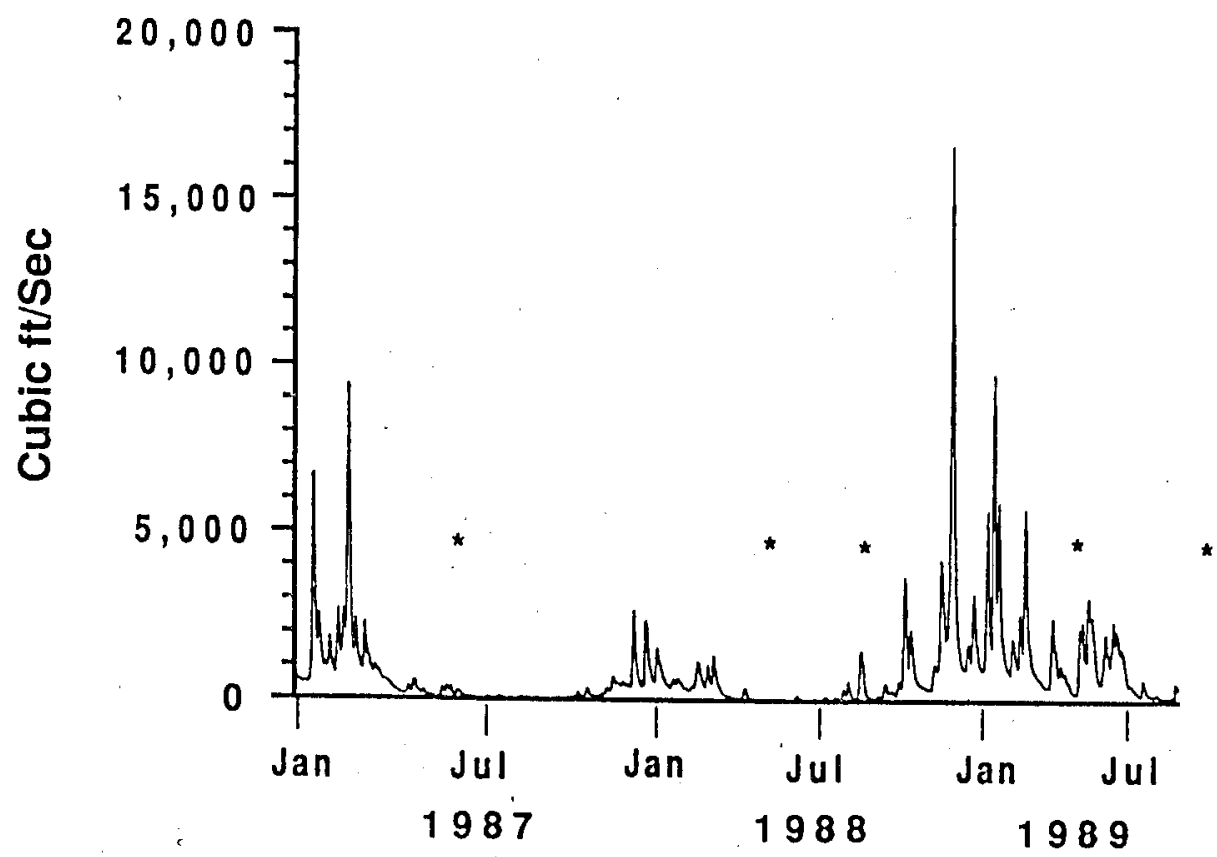

b. Average daily discharge during the study period (sampling periods are noted with an asterisk)

Figure 2. Average daily discharge at Luxapalila Creek, Mississippi 
Water chemistry

23. The water in Luxapalila Creek was moderately low in both calcium hardness (averaging 7 to $8 \mathrm{mg} / \mathrm{l}$ ) and alkalinity (averaging 7-10 $\mathrm{mg} / \mathrm{l}$ ), was slightly acidic, and was clear to moderately turbid (Figures 3a-3d). Dissolved oxygen was high $(6.6-8.2 \mathrm{mg} / \ell)$ and was always greater than 90 -percent air saturation on dates when macroinvertebrate and sediment samples were taken. These aspects of water chemistry are related to land use and soil conditions in the basin. The low hardness and alkalinity reflect moderate to low deposits of limestone. Clear to moderate turbidity is a consequence of lack of heavily farmed agricultural land.

24. Community composition and density of benthic invertebrates are primarily affected by substrate composition and water velocity (Hynes 1970). It should be noted that lakes and rivers low in carbonates are generally not as productive (i.e., producing large amounts of biomass per unit of time) as hard-water habitats (Russel1-Hunter 1970). Despite their generally lower productivity, soft-water habitats that are relatively unaffected by industrial, agricultural, or residential development (such as Luxapalila Creek) provide valuable habitat for a diverse fauna.

Sediment characteristics

25. The substrate of Luxapalila Creek can be characterized as poorly sorted gravel and coarse sand (Figures $4 \mathrm{a}$ and $4 \mathrm{~b}$ ). At all sites the silt-clay fraction $(<0.02 \mathrm{~mm}$ ), and cobble fraction $(<100 \mathrm{~mm}$ ) each constituted less than 5 percent of the total sediment weight. Median grain sizes for all samples ranged from 4.11 to $18.13 \mathrm{~mm}$; sorting coefficients ranged from 0.90 to 2.72. Pools typically had slightly smaller median particle diameters than did riffles $(7.79, \pm 2.32$ ( \pm standard deviation (SD)) versus $10.23 \pm 4.56$, respectively). However, these differences are nonsignificant and should not obscure the fact that with respect to substrate characteristics pools and riffles in Luxapalila Creek are relatively similar. Differences between pools and riffles were affected by season. During the summer, when discharge events capable of redistributing gravel became less frequent, differences between pools and riffles became even'less apparent.

26. The average substrate organic content at all sites and habitat types was low and equaled 1.18 percent $( \pm 0.89)$. There was no significant difference in percentage organic carbon between pools $(1.05, \pm 0.41)$ and riffles $(1.31, \pm 1.19)$. In addition, there were no significant differences among stations (pools and riffles combined) for all dates. Average organic content 


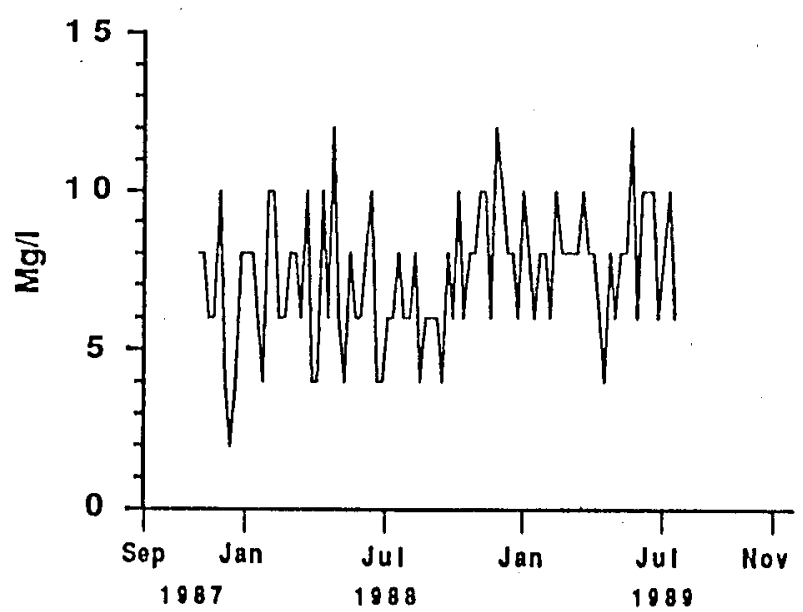

a. Calcium

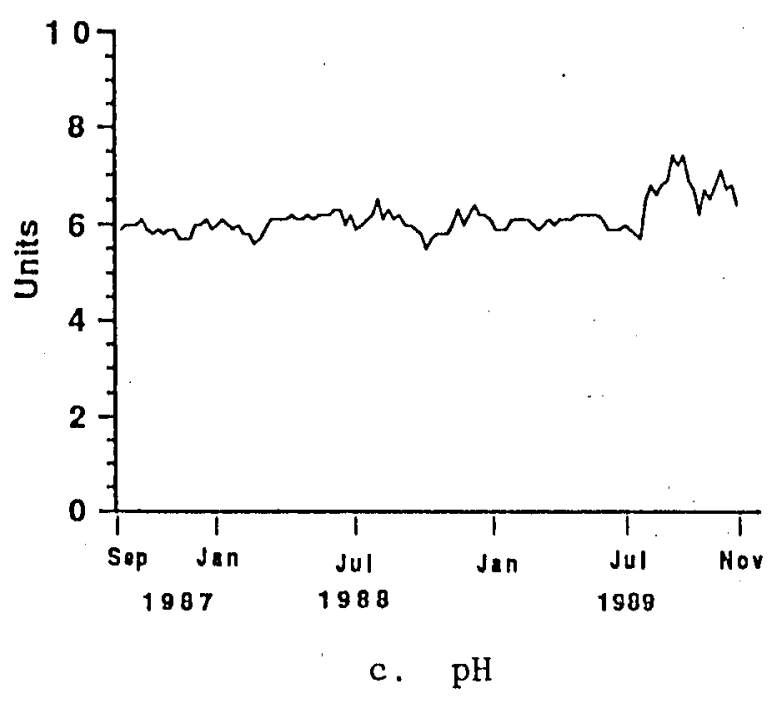

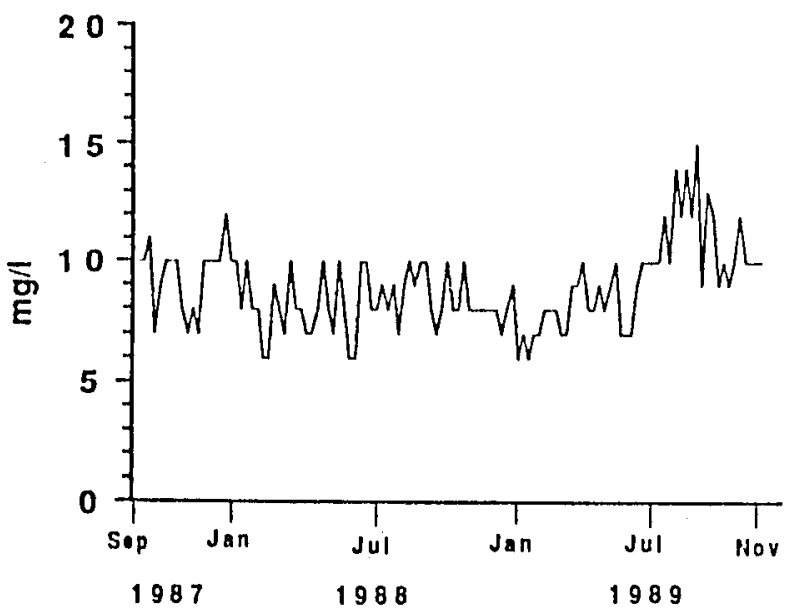

b. Total alkalinity

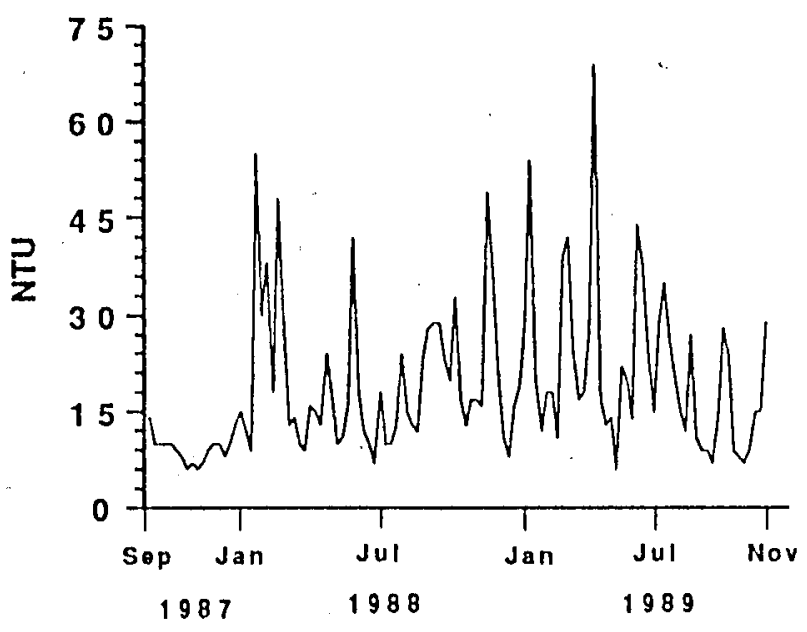

d. Turbidity

Figure 3. Five-day averages for selected water quality parameters at Columbus, Luxapalila Creek, Mississippi.

Data courtesy of the Columbus Water Department 


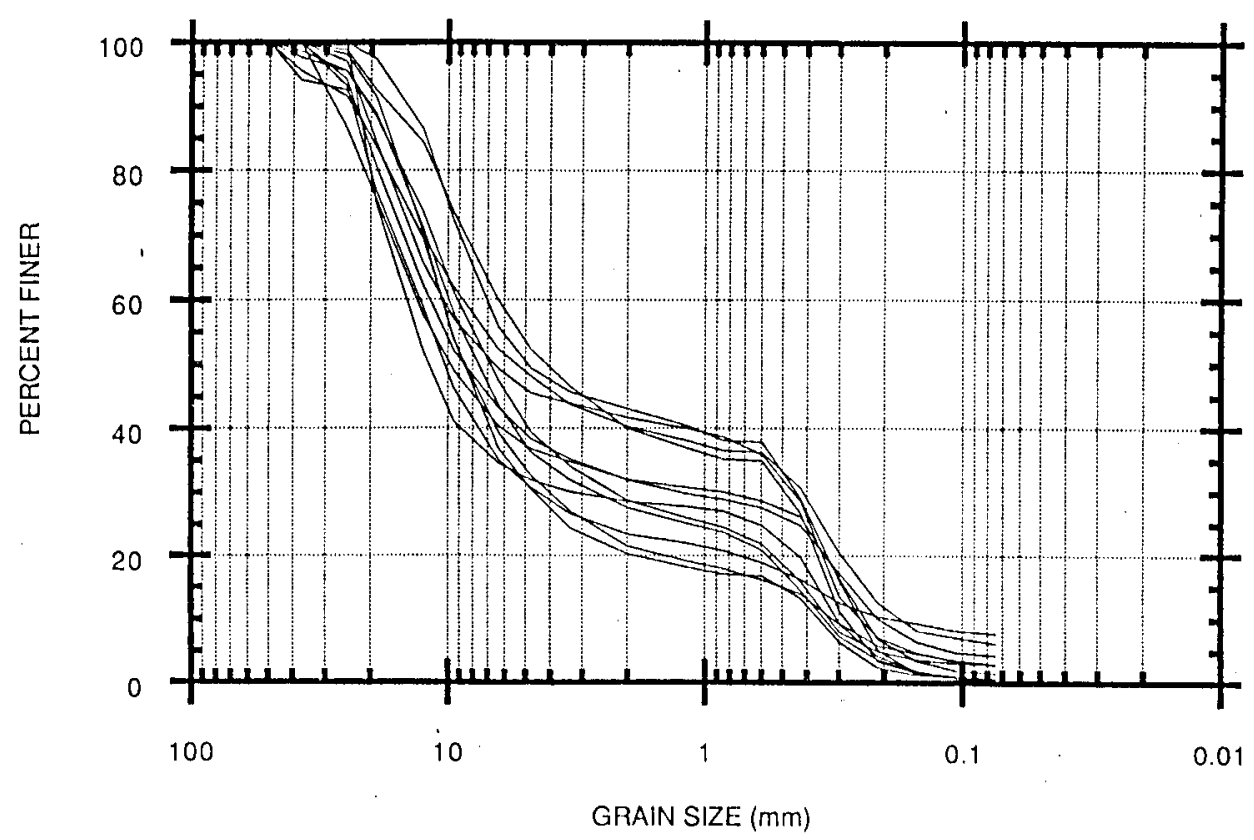

a. Pools

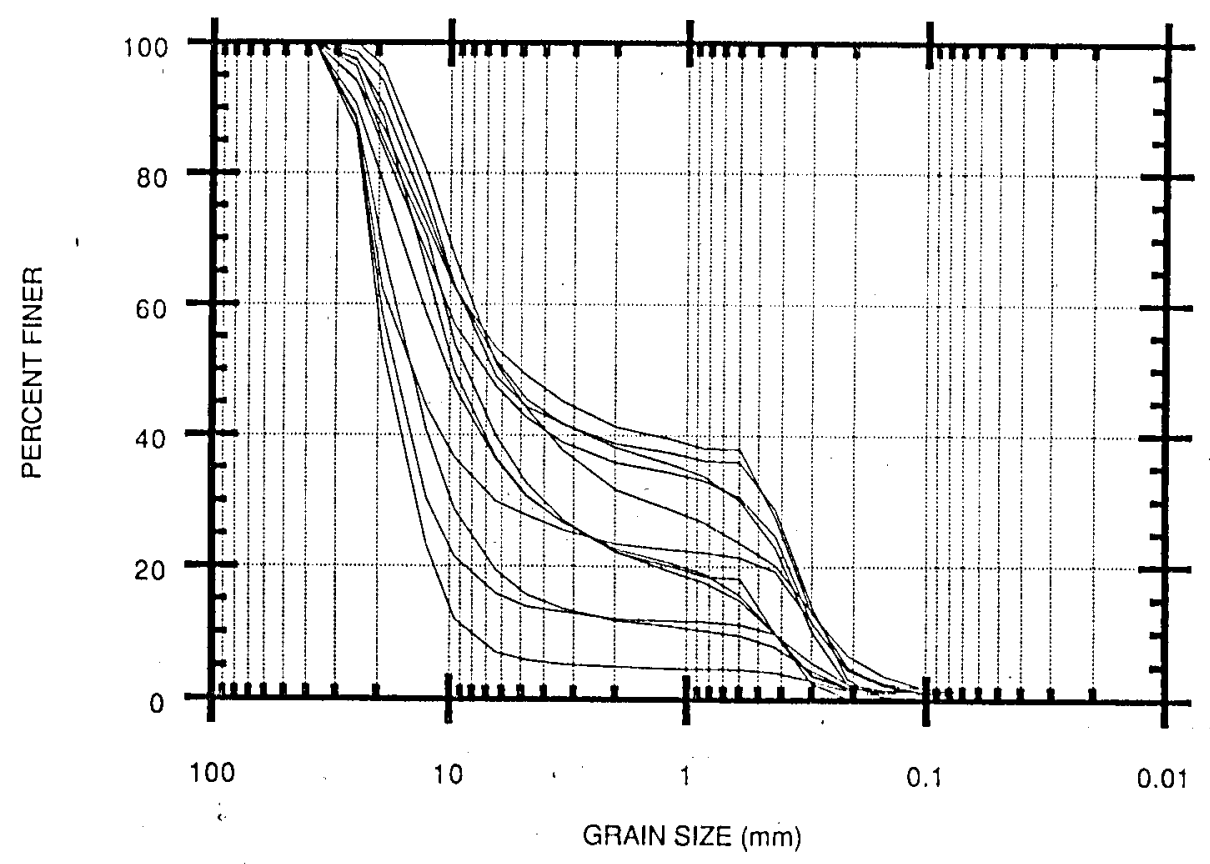

b. Riffles

Figure 4. Sediment characteristics in pools and riffles in Luxapalila Creek, Mississippi and Alabama during the study period. 
for all dates was $1.2( \pm 0.63), 1.1( \pm 0.47), 0.93,( \pm 0.33)$, and 0.88 $( \pm 0.41)$ for sites $1,2,3$, and 4 , respectively. There was no significant difference in organic content with respect to season, although organic contents of sediments were slightly less during the spring $(0.91, \pm 0.45)$ than in the fall $(1.5 \leq(1.5, \pm 1.15)$.

\section{Biological Conditions}

\section{Macroinvertebrate density}

27. The density of macroinvertebrates, averaged for all pools and dates, equaled 7,364 individuals per sq $\mathrm{m}$. Variation in average macroinvertebrate density in pools was not great among sites or dates (Figure 5a). The lowest average density was observed at pool 4 in October 1988 and equaled 5,427 individuals per sq $\mathrm{m}$; the highest average density of 12,561 individuals per sq $m$ was observed at pool 2 in September 1987. Neither spatial nor seasonal density patterns were evident among sites and dates. The ratio of the total range of variation in average density $(7,134$ individuals per $\mathrm{sq} \mathrm{m})$ to the overall average density (7,364 individuals per sq $\mathrm{m}$ ) equaled 1.0. This low value indicated lack of extreme variation in macroinvertebrate density data among pools and sampling dates.

28. In contrast to pools, average macroinvertebrate density in riffles varied greatly among sites and dates (Figure 5b). Averaged for all sites and dates, macroinvertebrate density in riffles equaled 15,964 individuals per sq $\mathrm{m}$ and was slightly greater than twice the overall average density in pools. At sites 1, 2, and 3 (sampled from fall 1987 through spring 1989), average density appeared to follow a seasonal pattern. At each of these sites, the average density in spring was substantially less than in the preceding fall. At site 4, the average density of macroinvertebrates declined between spring 1988 and fall 1989; however, density at this site declined between October 1988 and June 1989 as was observed at the other three riffles. Site- and date-specific average densities in riffles varied from 2,184 (riffle 4, November 1989) to 40,276.(riffle 2, September 1987). individuals per sq $m$. The ratio of this range $(38,092$ individuals per. $\mathrm{sq} \mathrm{m})$ to the overall average density $(15,964$ individuals per $\mathrm{sq} \mathrm{m}$ ) equaled 2.4, indicating greater than twice as much variation in total macroinvertebrates in riffles than in pools. 


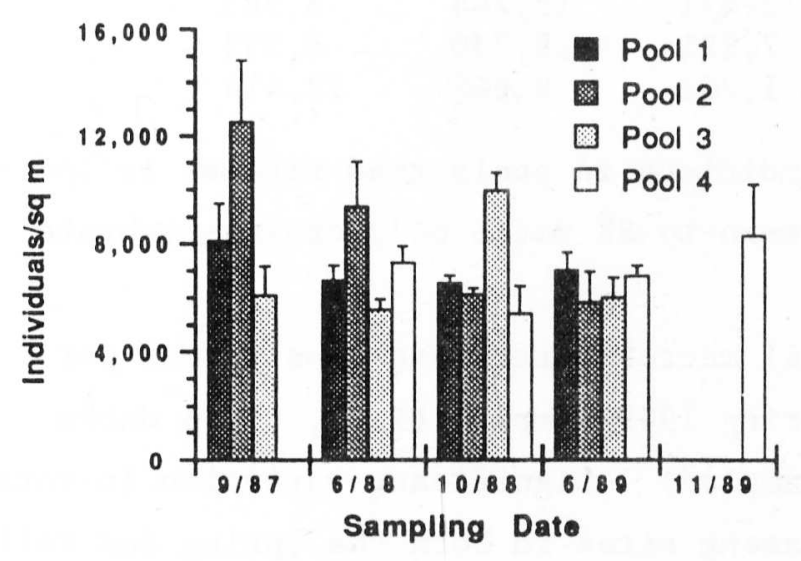

a. Density $(\overline{\mathrm{x}} \pm \mathrm{SE})$ of all macroinvertebrates in pools

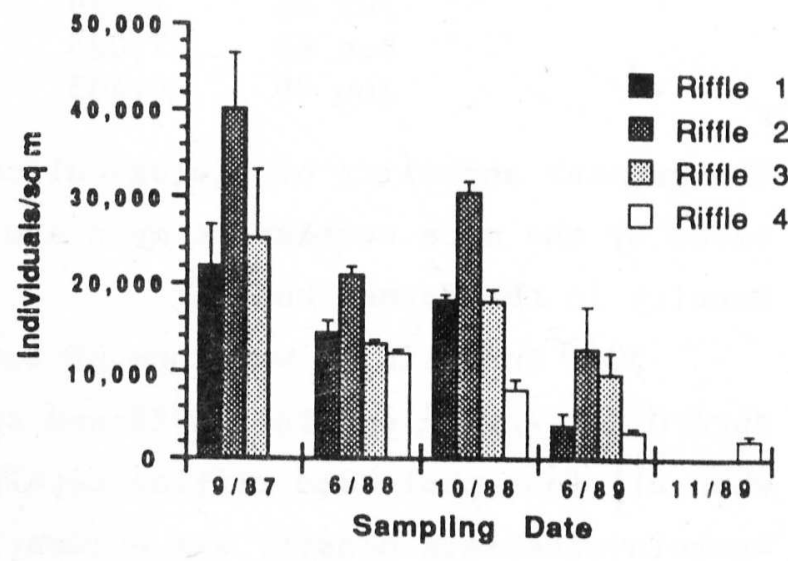

b. Density $(\bar{x} \pm S E)$ of all macroinvertebrates in riffles

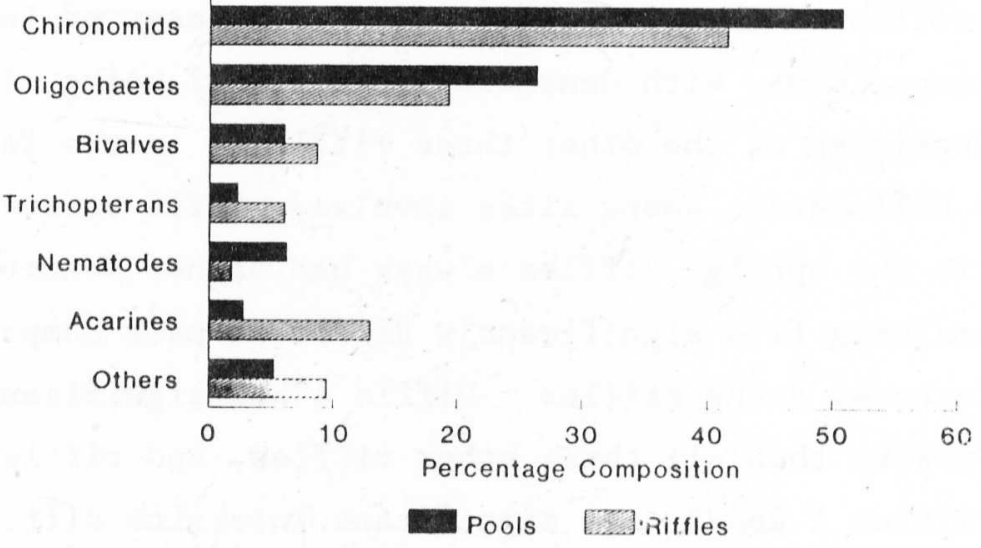

Iux 1

c. Percentage composition of major macroinvertebrates in pools and riffles

Figure 5. Characteristics of macroinvertebrates in Luxapalila Creek, Mississippi and Alabama, 1987-89 
29. A summary of mean macroinvertebrate density (and standard error, $\mathrm{SE}$ ) by sampling date and habitat type, appears below:

\begin{tabular}{|c|c|c|c|c|}
\hline \multirow[b]{2}{*}{ Date } & \multicolumn{2}{|c|}{ Pools } & \multicolumn{2}{|c|}{ Riffles } \\
\hline & Mean & $\mathrm{SE}$ & Mean & SE \\
\hline Sep 87 & 8,587 & 4,426 & 28,820 & 20,469 \\
\hline Jun 88 & 7,229 & 2,421 & 15,248 & 3,985 \\
\hline Oct 88 & 7,025 & 2,221 & 18,730 & 8,553 \\
\hline Jun 89 & 6,433 & 1,701 & 9,662 & 12,614 \\
\hline
\end{tabular}

The greater stability of biological conditions in pools than riffles is indicated by the more consistent mean and mean-to-SE ratio of macroinvertebrate density in the former habitat.

30. Analysis of variance of total macroinvertebrate density was performed for spring and fall 1988 and spring 1989 samples (i.e., those dates when all four pools and riffles were sampled). Significant variation in total macroinvertebrate density was evident among sites in both the spring and fall of 1988 (Table 1). Paired comparisons of sites confirmed the intersite patterns in Figures $5 \mathrm{a}$ and $5 \mathrm{~b}$; namely, density was higher in riffles than pools, intersite variation among riffles was high, and intersite variation among pools was low (Table 2). In both the spring and fall of 1988, 17 of 28 possible pairwise combinations between sites revealed significant differences. In the spring of 1988,14 of these significant differences were for poolversus-riffle comparisons, and all such comparisons indicated lower densities in pools than riffles. The remaining differences observed in spring involved inter-riffle comparisons, with densities at riffle 2 being significantly greater than densities at the other three riffles. In the fall, 12 of the 17 significant differences among sites involved riffle-versus-pool comparisons, and, as in the spring, riffles always had higher densities than did pools. The remaining five significantly different pair comparisons involved intersite differences among riffles. Riffle 4 had significantly lower macroinvertebrate density than all three other riffles, and riffle 2 had higher density than riffles 1 and 3 . No significant intersite differences among pools were evident in either the spring or fall of 1988 .

31. Lack of significant intersite differences (i.e., among pool, pool versus riffle, or among riffle) in total macroinvertebrate densities in the spring of 1989 (Table 1) was principally the result of the reduction in density in riffles during that sampling period (Figure 5b). These low densities in riffles in the spring of 1989 eliminated pool-versus-riffle differences 
Table 1

Analysis of Variance of Total Macroinvertebrate Density at al1 Sites

in Luxapalila Creek, Spring and Fall, 1988 and Spring, 1989

\begin{tabular}{|c|c|c|c|c|c|c|}
\hline Date & Source & $\underline{\mathrm{DF}}$ & Sum Squares & Mean Square & $F$ & $p$ \\
\hline $\begin{array}{l}\text { Spring } \\
1988\end{array}$ & $\begin{array}{l}\text { Between sites } \\
\text { Within sites } \\
\text { Total }\end{array}$ & $\begin{array}{r}7 \\
32 \\
39\end{array}$ & $\begin{array}{r}53,180 \\
8,346 \\
61,526\end{array}$ & $\begin{array}{r}7,597 \\
261 \\
\end{array}$ & 29.1 & 0.0001 \\
\hline $\begin{array}{l}\text { Fa11 } \\
1988\end{array}$ & $\begin{array}{l}\text { Between sites } \\
\text { Within sites } \\
\text { Total }\end{array}$ & $\begin{array}{r}7 \\
32 \\
39\end{array}$ & $\begin{array}{r}167,338 \\
8,592 \\
175,930\end{array}$ & $\begin{array}{r}23,905 \\
269\end{array}$ & 89.0 & 0.0001 \\
\hline $\begin{array}{l}\text { Spring } \\
1989\end{array}$ & $\begin{array}{l}\text { Between sites } \\
\text { Within sites } \\
\text { Total }\end{array}$ & $\begin{array}{r}7 \\
32 \\
39\end{array}$ & $\begin{array}{r}58,217 \\
137,881 \\
196,098\end{array}$ & $\begin{array}{l}8,317 \\
4,309\end{array}$ & 1.93 & $0.097 *$ \\
\hline
\end{tabular}

* Not significant at the 0.05 level.

that were evident in 1988. Furthermore, within-riffle density in the spring of 1989 was high and obscured the between-riffle differences that were evident in the spring of 1989.

32. Chironomids and oligochaetes were the numerically dominant macroinvertebrates in both pools and riffles (Figure 5c). These two taxa comprised an average of 77 and 62 percent of all macroinvertebrates in Luxapalila Creek pools and riffles, respectively. Corbicula fluminea, trichopterans (caddisflies), acarines (mites), and nematodes (unsegmented worms) were less abundant than chironomids and oligochaetes but also comprised a substantial proportion of the total macroinvertebrate community. The bivalve community was dominated by the introduced Asiatic clam, Corbicula fluminea. Dominant trichopterans were Hydroptila and Chimarra. Bivalves, trichopterans, and acarines were more abundant in riffles than pools, but nematodes were more abundant in pools than riffles. Corbicula, Hydroptila, and Chimarra typically are found in lotic habitats. Neither acarines nor nematodes were identified to a lower taxonomic leve1.

33. The average density of chironomids, the dominant major taxon, was less variable in pools (Figure 6a) than in riffles (Figure 6b). Maximum density of this group was higher and minimum density was lower in riffles than pools. Averaged for all sites and dates, chironomid density in pools and riffles was 3,981 and 7,419 individuals per sq $\mathrm{m}$, respectively. Site- and 
Table 2

Paired Comparisons of Site-Specific Density of Total Macroinvertebrates

in Luxapalila Creek. Spring and Fall 1988

\begin{tabular}{|c|c|c|c|c|c|}
\hline & & Spring & 1988 & Fall & 88 \\
\hline & & $\begin{array}{c}\text { Mean } \\
\text { Difference* }\end{array}$ & $\begin{array}{c}\text { Scheffe's } \\
\text { F-test }\end{array}$ & $\begin{array}{c}\text { Mean } \\
\text { Difference* }\end{array}$ & $\begin{array}{c}\text { Scheffe's } \\
\text { F-test }\end{array}$ \\
\hline & $\mathrm{P} 1$ vs $\mathrm{P} 2$ & -15.4 & 0.325 & 3.2 & 0.014 \\
\hline & $\mathrm{P} 1$ vs $\mathrm{P} 3$ & 8.4 & 0.097 & -27.0 & 0.970 \\
\hline Interpool & $\mathrm{P} 1$ vs $\mathrm{P} 4$ & -5.8 & 0.046 & 8.8 & 0.103 \\
\hline comparisons & $\mathrm{P} 2$ vs $\mathrm{P} 3$ & 23.8 & 0.776 & -30.2 & 1.213 \\
\hline & $\mathrm{P} 2$ vs $\mathrm{P} 4$ & 9.6 & 0.126 & 5.6 & 0.042 \\
\hline & $\mathrm{P} 3$ vs $\mathrm{P} 4$ & -14.2 & 0.276 & 35.8 & 1.705 \\
\hline & $\mathrm{P} 1$ vs $\mathrm{R} 1$ & -62.0 & $5.264 * x$ & -92.0 & $11.258 \times *$ \\
\hline & $\mathrm{P} 1$ vs R2 & -106.8 & $15.620 * x$ & -188.8 & $47.413 * *$ \\
\hline & $\mathrm{P} 1$ vs $\mathrm{R} 3$ & -51.2 & $3.590 * x$ & -90.4 & $10.870 * x$ \\
\hline & $\mathrm{P} 1$ vs $\mathrm{R} 4$ & -47.0 & $3.025 * *$ & -11.4 & 0.173 \\
\hline & $\mathrm{P} 2$ vs $\mathrm{R} 1$ & -46.6 & $2.974 * x$ & -95.2 & $12.055 * *$ \\
\hline & $\mathrm{P} 2$ vs $\mathrm{R} 2$ & -91.4 & $11.440 * * x$ & -192.0 & $49.034 * *$ \\
\hline & $\mathrm{P} 2$ vs $\mathrm{R} 3$ & -35.8 & 1.755 & -93.6 & $11.653 * *$ \\
\hline Pool-to- & $\mathrm{P} 2$ vs $\mathrm{R} 4$ & -31.6 & 1.367 & -14.6 & 0.284 \\
\hline riffle & P3 vs R1 & -70.4 & $6.787 * x$ & -65.0 & $5.620 * x$ \\
\hline comparisons & $\mathrm{P} 3$ vs $\mathrm{R} 2$ & -115.2 & $18.174 * x$ & -161.8 & $34.822 * *$ \\
\hline & P3 vs R3 & -59.6 & $4.864 x x$ & -63.4 & $5.347 * x$ \\
\hline & P3 vs R4 & -55.4 & $4.203 * x$ & 15.6 & 0.324 \\
\hline & P4 vs R1 & -56.2 & $4.325 * x$ & -100.8 & $13.515 \%$ \\
\hline & $\mathrm{P} 4$ vs $\mathrm{R} 2$ & -101.0 & $13.969 * *$ & -197.6 & $51.936 * x$ \\
\hline & $\mathrm{P} 4$ vs $\mathrm{R} 3$ & -45.4 & 2.823 & -99.2 & $13.089 * *$ \\
\hline & $\mathrm{P} 4$ vs $\mathrm{R} 4$ & -41.2 & $2.324 * x$ & -20.2 & 0.543 \\
\hline & R1 vs $R 2$ & -44.8 & $2.748 * x$ & -96.8 & $12.464 * x$ \\
\hline & $\mathrm{R} 1$ vs $\mathrm{R} 3$ & 10.8 & 0.160 & 1.6 & 0.003 \\
\hline Inter-riffle & R1 vs R4: & 15.0 & 0.308 & 80.6 & $8.641 * x$ \\
\hline comparisons & $\mathrm{R} 2$ vs $\mathrm{R} 3$ & 55.6 & $4.233 * *$ & 98.4 & $12.879 * *$ \\
\hline & $\mathrm{R} 2$ vs $\mathrm{R} 4$ & 59.8 & $4.897 * *$ & 177.4 & $41.861 * *$ \\
\hline & $\mathrm{R} 3$ vs $\mathrm{R} 4$ & 4.2 & 0.024 & 79.0 & $8.301 * x$ \\
\hline
\end{tabular}

\footnotetext{
* Negative values indicate lower mean density at first site listed for each paired comparison.

** Probability of $\mathrm{F}<0.05$.
} 
date-specific average density ranged from 1,953 to 7,036 individuals per sq $\mathrm{m}$ in pools and from 709 to 21,139 individuals per sq $m$ in riffles. The ratios of these ranges to the overall average densities in pools and riffles were 1.3 and 2.9 , respectively. In pools, variation of chironomid density did not follow a discernible intersite or seasonal pattern. In riffles, chironomid density was generally lowest in riffle 4 and highest in riffle 2 . The seasonal pattern for total macroinvertebrates of lower density in spring than in the preceding fall was evident for chironomids in riffles 1 and 2 . Riffle 1 was especially depauperate of chironomids in June 1989 compared to the three previous dates, and all four riffles had relatively low chironomid densities in June 1989.

34. The average density of oligochaetes was similar in pools and riffles and varied greatly among sites and dates (Figures $6 \mathrm{c}$ and $6 \mathrm{~d}$ ). Averaged for all sites and dates, the densities of oligochaetes in pools and riffles were 1,697 and 2,861 individuals per sq $\mathrm{m}$, respectively. Site- and datespecific average densities of oligochaetes ranged from 178 to 3,620 and from 51 to 9,709 individuals per sq $\mathrm{m}$ in pools and riffles, respectively. Exceptionally low densities were observed during June 1989 (pools 2 and 4 and riffle 4) and in November 1989 in both the pool and riffle of site 4 (the only site samples in November 1989).

35. Corbicula fluminea, which was moderately abundant in riffles, had especially low densities at all riffles in June 1989 (Figure 7). Less than 500 individuals per sq $\mathrm{m}$ were found at riffle 1 in the spring of 1989 , although densities of this clam had averaged 2,000 individuals per sq m during 1988. In riffles 2 and 3; 1988 densities of $C$. fluminea averaged 1,000 and 2,750 individuals per sq $\mathrm{m}$, respectively, but no Asiatic clams were collected from these two riffles in June 1989. No $C$. fluminea were found in riffle 4 in June 1989, although high density populations were never noted at this site. Community composition

36. In Luxapalila Creek the abundant chironomid and oligochaete communities were rich in species. In both pools and riffles, cumulative species of chironomids and aligochaetes was a linear function of the cumulative number of individuals (Figures $8 \mathrm{a}$ and $8 \mathrm{~b}$ ). The rate of acquisition of new species was clearly higher in pools than riffles. In pools, 63 species of chironomids were represented among 1,503 individuals identified to the species level. In riffles, 50 species of chironomids were represented among 1,910 individuals. 


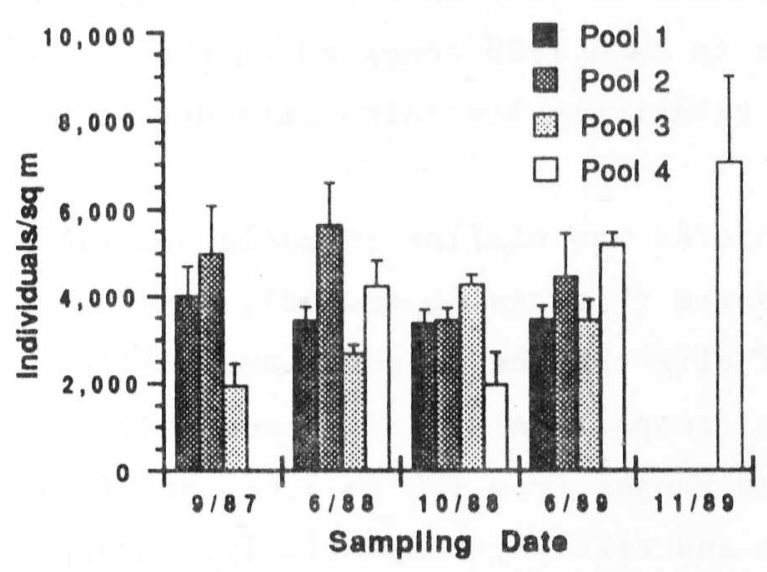

a. Chironomids in pools

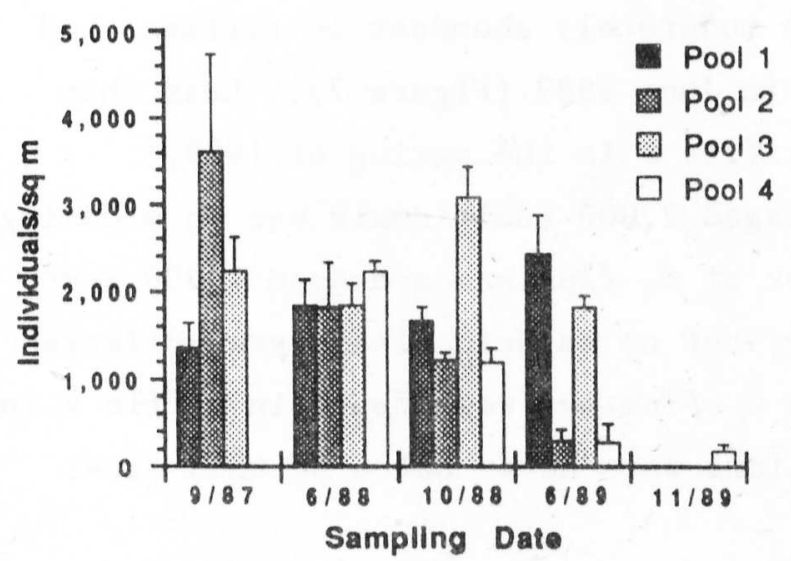

c. Oligochaetes in pools

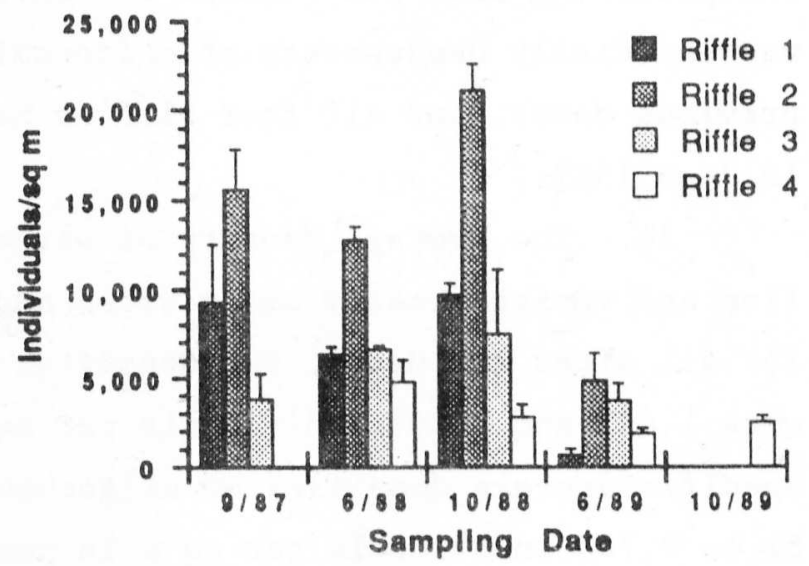

b. Chironomids in riffles

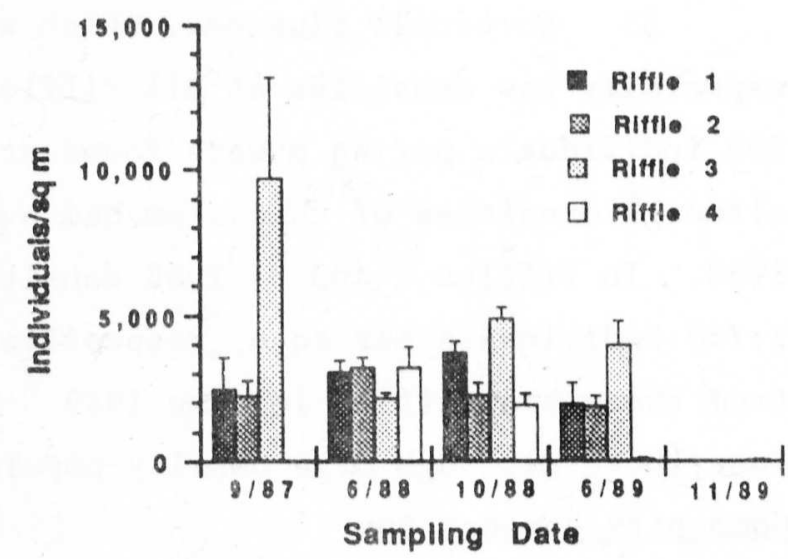

d. Oligochaetes in riffles

Figure 6. Total density of chironomids and oligochaetes in pools and riffles, Luxapalila Creek, Mississippi and Alabama, 1987-89 


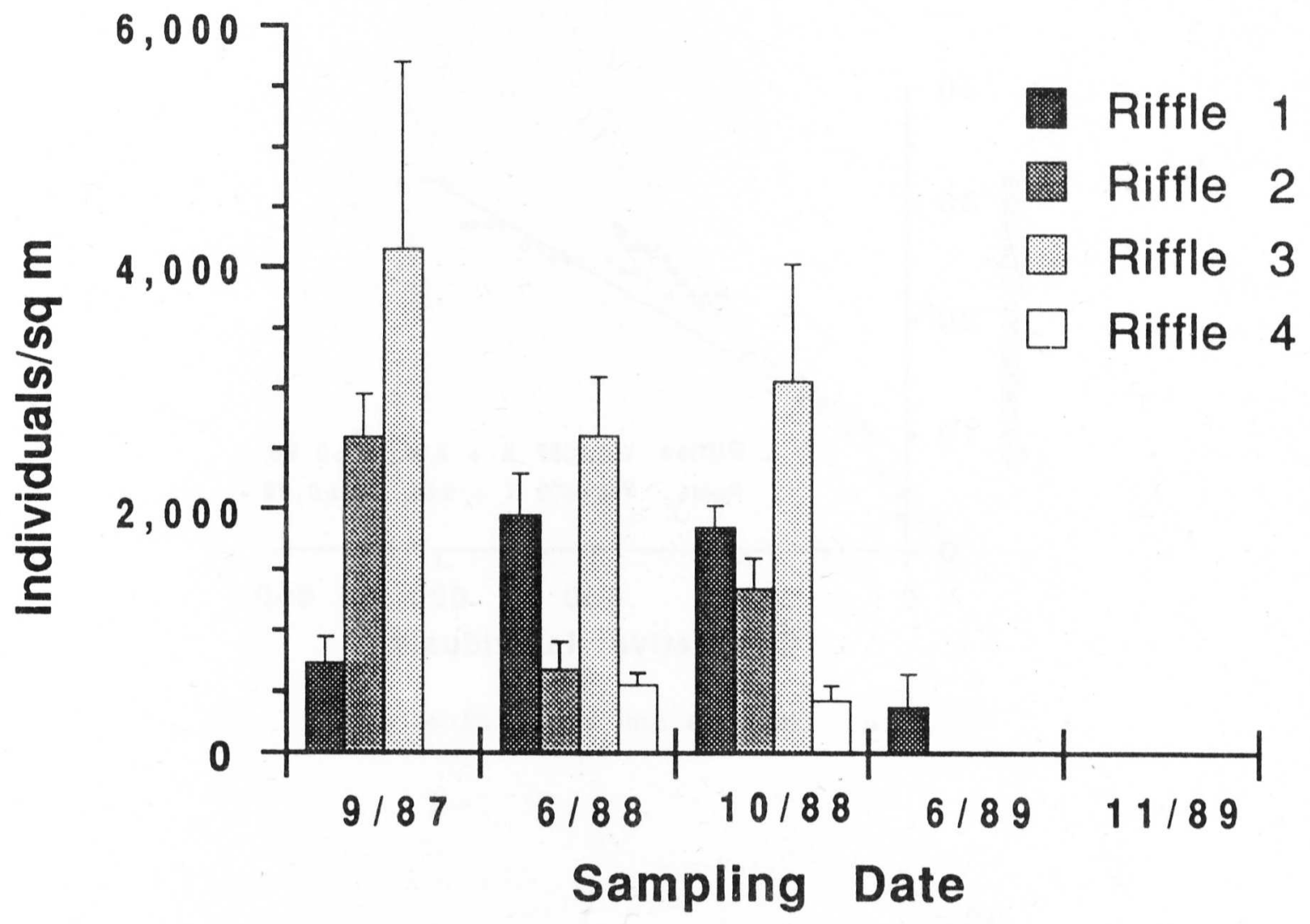

Figure 7. Total density of Corbicula fluminea in riffles in Luxapalila Creek, Mississippi and Alabama, 1987-89

37. The distribution of individuals among species of both chironomids and oligochaetes was highly equitable (i.e., evenly distributed) based on Simpson's index of equitability (Simpson 1949), and equitability was slightly higher in pools than riffles (Tables 3 and 4 for chironomids and oligochaetes, respectively). The value of this index equals one minus the sum of the proportional abundance of each species in a community. The index is relatively insensitive to underestimation of species richness and ranges from theoretical minima and maxima approaching 0.0 and 1.0 , respectively. Values between 0.2 and 0.8 are observed in most samples of naturally occurring communities (e.g., Whittaker 1965). Simpson's index of equitability was slightly less than 1.0 for both taxonomic groups in both habitats (Tables 3 and 4 for chironomids and oligochaetes, respectively). The theoretical maximum equitability of chironomids in pools would have been observed if there was equal distribution of the 1,503 individuals among all 63 species identified from pool samples (Simpson's 


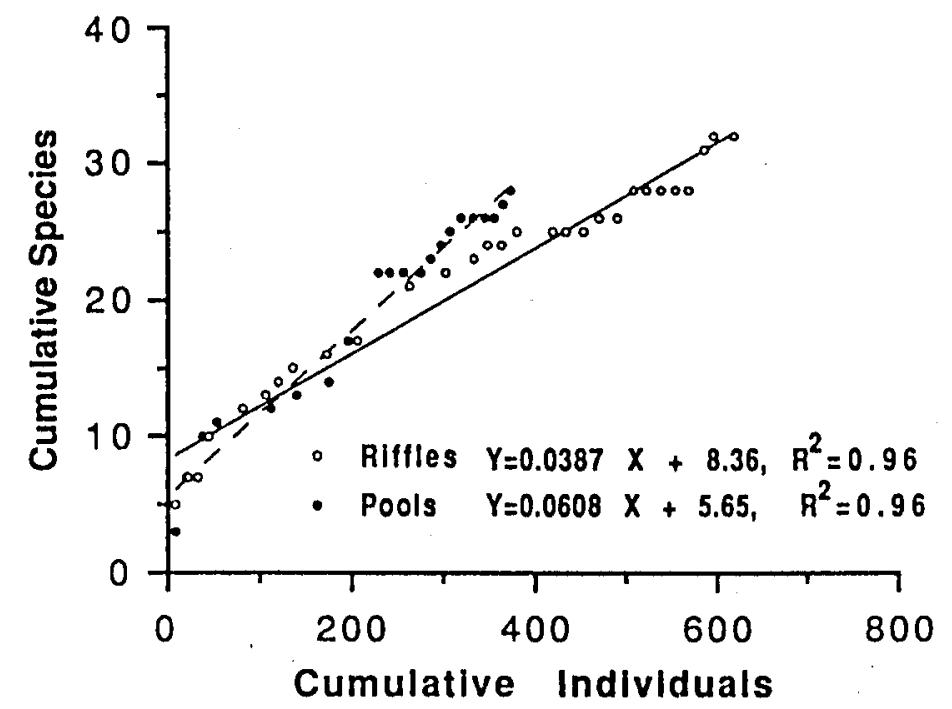

a. Naidids and tubificids

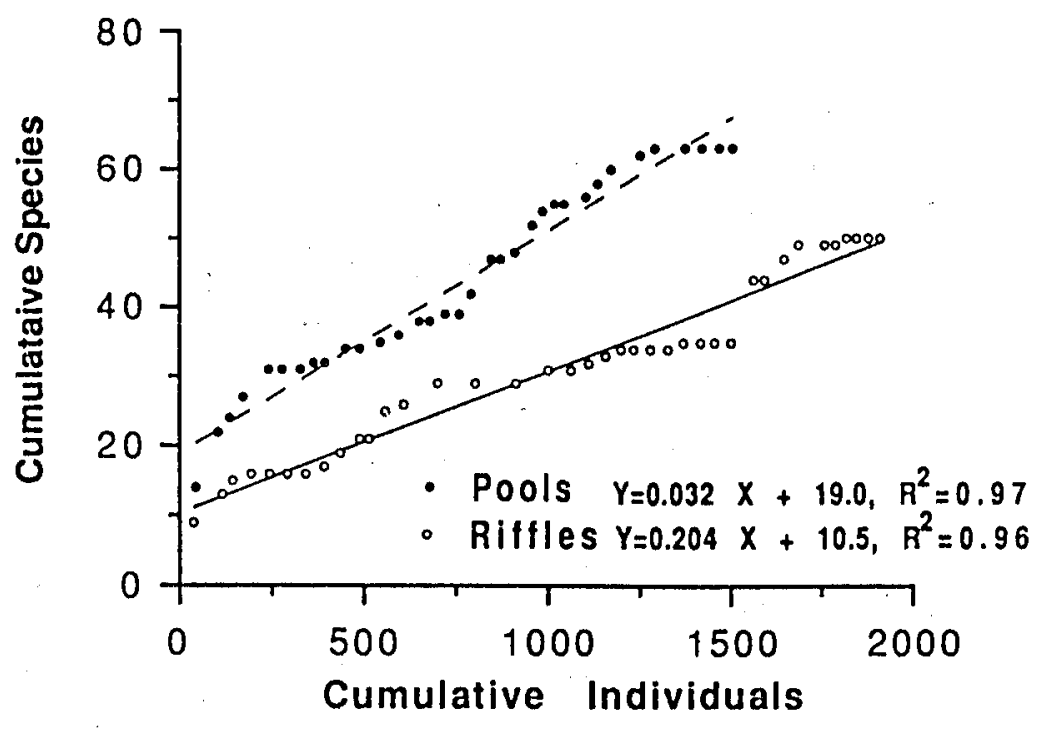

b. Chironomids

Figure 8. Species richness as a function of cumulative individuals for oligochaetes and chironomids, Luxapalila Creek, Mississippi and Alabama, 1987-89 
Table 3

Distribution of Individuals Among Species of Chironomids in Luxapalila Creek. Mississippi*

\begin{tabular}{|c|c|c|c|c|}
\hline \multirow{2}{*}{ Species } & \multicolumn{2}{|c|}{ Pools } & \multicolumn{2}{|c|}{ Riffles } \\
\hline & $\ldots$ & $\mathrm{n}$ & 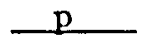 & $\mathrm{n}$ \\
\hline \multicolumn{5}{|l|}{ Chironomidae } \\
\hline \multirow{2}{*}{\multicolumn{5}{|c|}{$\begin{array}{l}\text { Chironominae } \\
\text { Chironomini }\end{array}$}} \\
\hline & & & & \\
\hline Chironomus sp. & 0.0160 & 24 & 0.0005 & 1 \\
\hline Cladopelma sp. & 0.0013 & 2 & 0.0000 & 0 \\
\hline Cryptochironomus fulvus & 0.0213 & 32 & 0.0011 & 2 \\
\hline Cryptochironomus sp. & 0.0027 & 4 & 0.0011 & 2 \\
\hline Dicrotendipes neomodestus & 0.0140 & 21 & 0.0661 & 124 \\
\hline Dicrotendipes nervosus Type I & 0.0319 & 48 & 0.0016 & 3 \\
\hline Dicrotendipes nervosus Type II & 0.0013 & 2 & 0.0000 & 0 \\
\hline Dicrotendipes sp. I & 0.0120 & 18 & 0.0080 & 15 \\
\hline Endochironomus sp. & 0.0093 & 14 & 0.0005 & 1 \\
\hline Glyptotendipes sp. & 0.0033 & 5 & 0.0005 & 1 \\
\hline Harnischia sp. & 0.0040 & 6 & 0.0005 & 1 \\
\hline Microtendipes sp. & 0.0007 & 1 & 0.0000 & 0 \\
\hline Nilothauma babiyi & 0.0106 & 16 & 0.0016 & 3 \\
\hline Parachironomus abortivus & 0.0020 & 3 & 0.0005 & 1 \\
\hline Paracladopelma undine & 0.1240 & 186 & 0.0016 & 3 \\
\hline Paralauterborniella nigrohalteralis & 0.0313 & 47 & 0.0016 & 3 \\
\hline Paratendipes albimanus & 0.0013 & 2 & 0.0000 & 0 \\
\hline Paratendipes nudisquama & 0.0007 & 1 & 0.0000 & 0 \\
\hline Phaenopsectra' dyari & 0.0838 & 126 & 0.0000 & 0 \\
\hline Phaenopsectra flavipes & 0.0186 & 28 & 0.0000 & 0 \\
\hline Polypedilum convictum & 0.0067 & 10 & 0.0762 & 143 \\
\hline Polypedilum fallax & 0.0013 & 2 & 0.0000 & 0 \\
\hline Polypedilum illinoense & 0.0126 & 19 & 0.0053 & 10 \\
\hline Polypedilum nr. scaloneum & 0.1190 & 179 & 0.0410 & 77 \\
\hline Pseudochironomus sp. & 0.0146 & 22 & 0.0016 & 3 \\
\hline Robackia sp. & 0.0033 & 5 & 0.0624 & 117 \\
\hline Stenochironomus sp. & 0.0007 & 1 & 0.0000 & 0 \\
\hline Stictochironomus sp. & 0.0020 & 3 & 0.0005 & 1 \\
\hline Tribelos sp. & 0.0000 & 0 & 0.0005 & 1 \\
\hline Xenochironomus sp. & 0.0053 & 8 & 0.0213 & 40 \\
\hline Unidentified chironomini & & 4 & & 5 \\
\hline \multicolumn{5}{|l|}{ Tanytarsini } \\
\hline Cladotanytarsus sp. & 0.0146 & 22 & 0.0320 & 10 \\
\hline Lauterborniella sp. & 0.0013 & 2 & 0.0000 & 0 \\
\hline Micropsectra sp. & 0.0033 & 5 & 0.0000 & 0 \\
\hline Rheotanytarsus sp. & 0.0140 & 21 & 0.0736 & 138 \\
\hline Stempellina sp. & 0.0013 & 2 & 0.0000 & 0 \\
\hline
\end{tabular}

(Continued)

* Note: $\mathrm{p}=$ relative abundance; $\mathrm{n}=$ number present. 
Table 3 (Concluded)

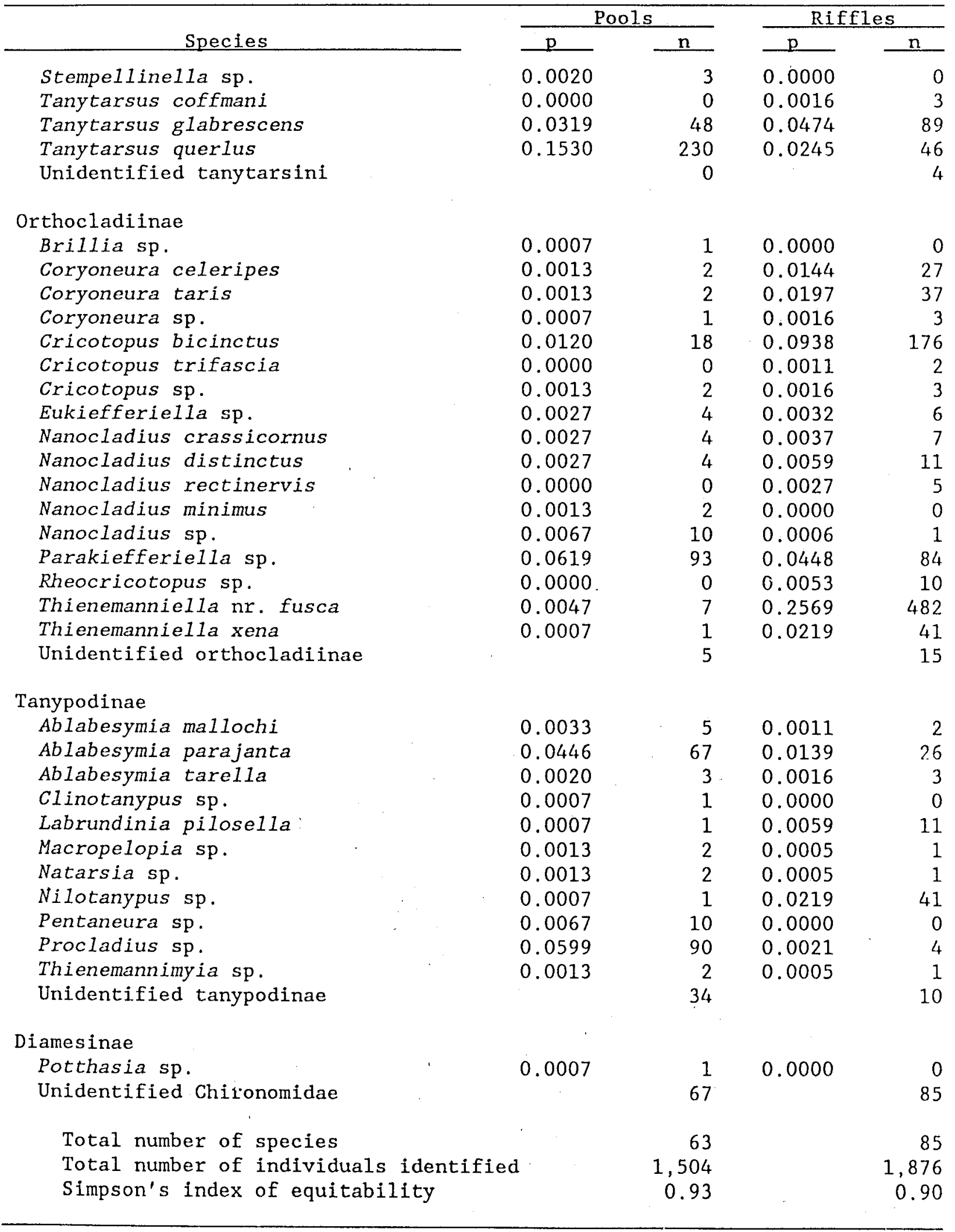


Table 4

Distribution of Individuals Among Species of Naidid and Tubificid Oligochaetes in Pool Versus Riffles in Luxapalila Creek, Mississippi*

\begin{tabular}{|c|c|c|c|c|}
\hline \multirow{2}{*}{$\begin{array}{c} \\
\text { Taxon } \\
\end{array}$} & \multicolumn{2}{|c|}{ Pools } & \multicolumn{2}{|c|}{ Riffles } \\
\hline & $\mathrm{n}$ & $\underline{p}$ & $\mathrm{n}$ & $\underline{p}$ \\
\hline \multicolumn{5}{|l|}{ Naididae } \\
\hline Amphichaeta leydigi & 6 & 0.0160 & 1 & 0.0016 \\
\hline Bratislavia bilongata & 0 & 0.0000 & 2 & 0.0033 \\
\hline Bratislavia unidenta & 0 & 0.0000 & 4 & 0.0065 \\
\hline Chaetogaster diaphanus & 3 & 0.0080 & 51 & 0.0831 \\
\hline Dero digitata & 3 & 0.0080 & 10 & 0.0163 \\
\hline Dero furcata & 13 & 0.0347 & 0 & 0.0000 \\
\hline Dero nivea & 8 & 0.0213 & 78 & 0.1270 \\
\hline Dero obtusa & 11 & 0.0293 & 76 & 0.1238 \\
\hline Dero trifida & 3 & 0.0080 & 9 & 0.0147 \\
\hline Dero sp. & 5 & 0.0133 & 3 & 0.0049 \\
\hline Homochaeta naidina & 1 & 0.0027 & 0 & 0.0000 \\
\hline Nais behningi & 0 & 0.0000 & 3 & 0.0049 \\
\hline Nais bretscheri & 0 & 0.0000 & 3 & 0.0049 \\
\hline Nais communis & 0 & 0.0000 & 3 & 0.0049 \\
\hline Nais elinquis & 1 & 0.0027 & 0 & 0.0000 \\
\hline Nais pardalis & 12 & 0.0320 & 90 & 0.1466 \\
\hline Nais pseudobtusa & 0 & 0.0000 & 10 & 0.0163 \\
\hline Nais simplex & 0 & 0.0000 & 3 & 0.0049 \\
\hline Nais variablis & 2 & 0.0053 & 53 & 0.0863 \\
\hline Piquetiella michiganensis & 5 & 0.0133 & 29 & 0.0472 \\
\hline Pristina aquiseta & 4 & 0.0107 & 28 & 0.0456 \\
\hline Pristina leidyi & 6 & 0.0160 & 33 & 0.0537 \\
\hline Pristina synclites & 29 & 0.0773 & 1 & 0.0016 \\
\hline Pristina sp. & 0 & 0.0000 & 1 & 0.0016 \\
\hline Pristinella jenkinae & 2 & 0.0053 & 1 & 0.0016 \\
\hline Pristinella longidentata & 3 & 0.0080 & 2 & 0.0033 \\
\hline Pristinella longisoma. & 0 & 0.0000 & 9 & 0.0147 \\
\hline Pristinella osborni & 8 & 0.0213 & 52 & 0.0847 \\
\hline Pristinella sima & 0 & 0.0000 & 2 & 0.0033 \\
\hline Slavina appendiculata & 2 & 0.0053 & 21 & 0.0342 \\
\hline Specaria josinae & 52 & 0.1387 & 1 & 0.0016 \\
\hline Stevensoniana trivandrama & 1 & 0.0027 & 26 & 0.0423 \\
\hline Total identified naidids & 180 & 0.4800 & 602 & 0.9805 \\
\hline Total unidentified naidids & 0 & & 8 & \\
\hline Total naidids & 180 & & 610 & \\
\hline
\end{tabular}

Tubificidae

$\begin{array}{lrrrr}\text { Aulodrilus limnobius } & 19 & 0.0507 & 0 & 0.0000 \\ \text { Aulodrilus piqueti } & 127 & 0.3387 & 4 & 0.0065 \\ & \text { (Continued) } & & & \end{array}$

* Note: $\mathrm{n}=$ number present; $\mathrm{p}=$ relative abundance. 
Table 4 (Concluded)

\begin{tabular}{|c|c|c|c|c|}
\hline \multirow[b]{2}{*}{ Taxon } & \multicolumn{2}{|c|}{ Pools } & \multicolumn{2}{|c|}{ Riffles } \\
\hline & $\mathrm{n}$ & $\underline{p}$ & $\mathrm{n}$ & $\underline{p}$ \\
\hline Aulodrilus pluriseta & 6 & 0.0160 & 0 & 0.0000 \\
\hline Branchiura sowerby & 31 & 0.0827 & 7 & 0.0114 \\
\hline Limnodrilus hoffmestri & 11 & 0.0293 & 0 & 0.0000 \\
\hline Limnodrilus rubripenis & 0 & 0.0000 & 1 & 0.0016 \\
\hline Total identified tubificids & 195 & 0.5200 & 12 & 0.0195 \\
\hline Total unidentified tubificids & 78 & & 28 & \\
\hline Total tubificids & 275 & & 40 & \\
\hline Tubificid-to-Naidid Ratio & 1.53 & & 0.07 & \\
\hline Simpson's Index of Equitability & 0.84 & & 0.91 & \\
\hline
\end{tabular}


index value equal to 0.98 ). In contrast, the most inequitable possible distribution would have been observed if there was a single individual of each of 62 species and 1,441 individuals of one extremely dominant species (Simpson's index equal to 0.08 ). The observed value of 0.92 is near the theoretical maximum of 0.98. Similarly high values were observed for chironomids in riffles and oligochaetes in both pools and riffles.

38. The unusually high equitability of chironomids and oligochaetes in pools and riffles was especially evident in plots of species-specific percentage abundance as a function of species rank (Figures 9a-9d). It is not unusual for the two or three most abundant species in a community of benthic macroinvertebrates to comprise 75-90 percent of the entire community. In Luxapalila Creek, no individual species comprised greater than 30 percent and the three most abundant species represented approximately 50 percent of the total community. Species relative abundance in these highly equitable communities spanned only 2.0 to 2.5 orders of magnitude in each community sample, although total species richness was high, ranging from 27-63.

39. Distinct differences were apparent in the most abundant species of chironomids in pools versus riffles, although at least a few individuals of most species could be found in either habitat type (Table 3). None of the six most abundant species in pools were among the six most abundant species in riffles. The six dominant chironomids in pools were Tanytarsus querlus (15.3 percent), Paracladopelma undine (12.4 percent), Polypedilum nr. scalaenum (11 percent) Phaenopsectra dyari ( 8.4 percent), Parakiefferiella sp. (6.2 percent), and Procladius ( 6.0 percent). All but one of these species ( $P$. dyari) were obtained in riffles as well as pools, although both $P$. undine and Procladius sp. were very uncommon in riffles. Tanytarsus querlus, $P$. nr. scalaenum, and Parakiefferiella sp. were moderately abundant in riffles; these species comprised $2.5,4.1$, and 4.5 percent, respectively, of the chironomids in riffles. Considered in total, the six most abundant species in pools comprised 60.2 percent of the pool assemblage of chironomids, versus 11.5 percent of the riffle assemblage of chironomids.

40. The six most abundant species of chironomids in riffles were Thienemanniella nr. fusca (25.7 percent), Cricotopus bicinctus (9.4 percent), Polypedilum convictum (7.6 percent), Rheotanytarsus sp. (7.4 percent), Dicrotendipes neomodestus ( 6.6 percent), and Robackia sp. ( 6.2 percent). The combined abundance of these six species in riffles and pools was 62.9 and 6.3 percent, respectively. None of the dominant species in riffles was found 


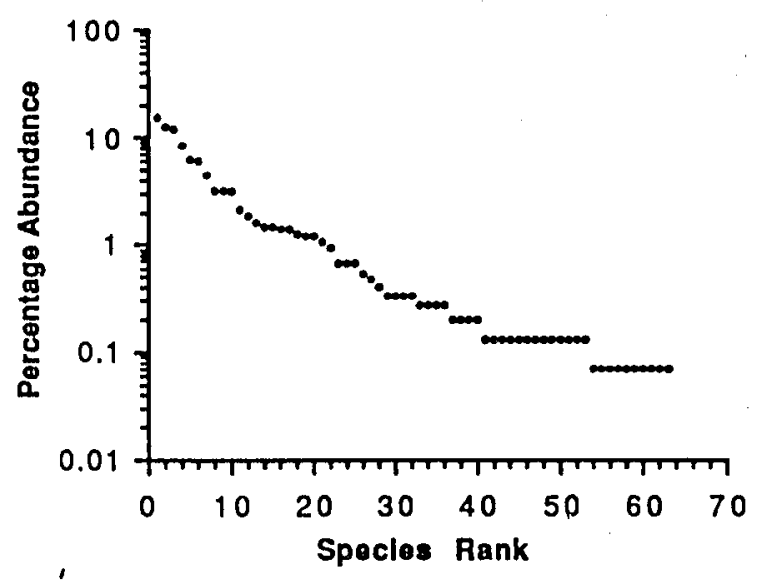

a. Chironomids in pools

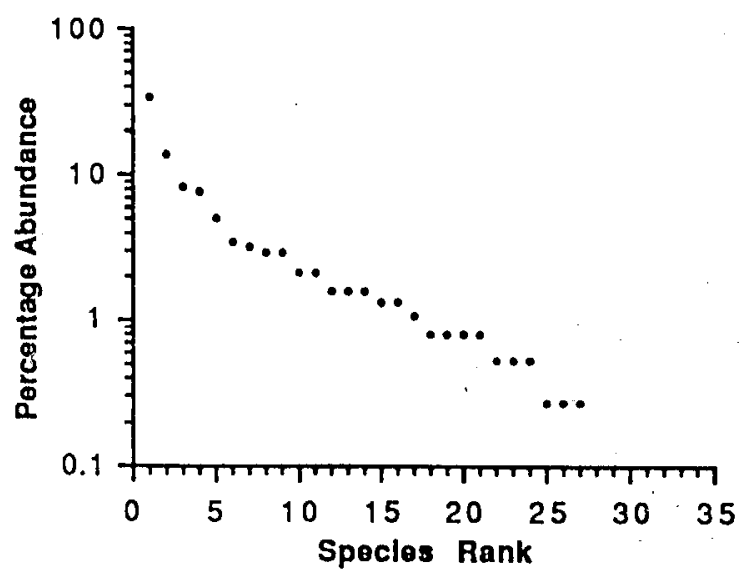

c. Naidids and tubificids in pools

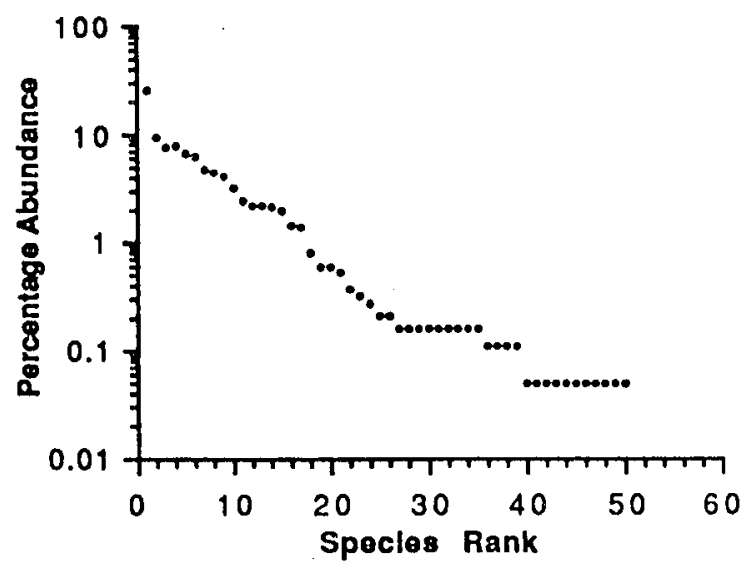

b. Chironomids in riffles

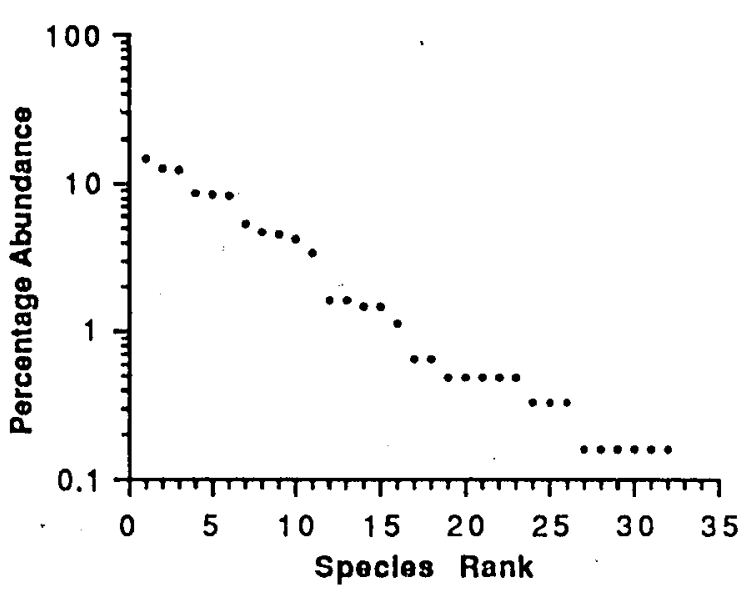

d. Naidids and tubificids in riffles

Figure 9. Species relative abundance in relation to dominance for chironomids and oligochates in pools and riffles, Luxapalila Creek, Mississippi and Alabama, 1987-89 
in greater than 1.6 percent abundance among pool-dwelling chironomids, although some individuals of all six species were obtained from the more lentic habitat.

41. Differences were also evident between pool and riffle chironomid communities among uncommon species. Eighteen uncommon species of chironomids were found in pools but not in riffles, but only four such species were found only in the riffles (Table 3). Community structure in terms of uncommon species must be evaluated cautiously, because a high degree of uncertainty is associated with presence or absence data for uncommon species. Nonetheless, the magnitude of pool-versus-riffle difference in the number of species unique to each habitat type (i.e., a ratio of 18 to 4) indicates that more species of this group probably occurred in pools than in riffles. Drift of chironomid larvae is a major means of dispersal in rivers and streams (Simpson and Bode 1980). Settlement of drifting larvae in pools is probably more likely than in riffles given the more depositional nature of the former habitat. Thus regardless of the origin of drifting chironomids, successful immigration via drift into pools is probably higher than into riffles and may account for the slightly greater richness observed in pools versus riffles.

42. As with chironomids, the pool community of oligochaetes was dominated by different species than the riffle community (Table 4). The six most abundant species in pools included three tubificids (Aulodrilus piqueti (33.9 percent), Branchiura sowerbyi ( 8.3 percent), and A. 1imnobius (3.5 percent)) and three naidids (Specaria josinae (13.9 percent), Pristina synclites (7.7 percent), and Dero furcata ( 3.5 percent)). Two of these species (A. limnobius and $D$. furcata) were not obtained in riffles, and the other four dominant species in pools were uncommon in riffles. The combined abundance of these six species was 72.4 percent in pools and only 2.2 percent in riffles. The six most abundant species in riffles were all naidids, and included Nais pardalis (14.7 percent), Dero nivea (12.7 percent), D. obtusa (12.4 percent), $N$. variables ( 8.6 percent), Pristinella osborni ( 8.5 percent), and Chaetogaster diaphanus ( 8.3 percent). All six of these species were also obtained from pools, four occurred in pools in moderate abundance (2.0 percent), but none individually comprised more than 3.2 percent of the oligochaete community in the more lentic habitat type. The combined abundance of these six species was 65.2 percent in riffles and 11.6 percent in pools.

43. As reflected in the species composition of dominant oligochaetes in pools and riffles, the pool community was a mixed assemblage of tubificids and 
naidids, but the riffle community was almost entirely comprised of naidids (Table 4). Tubificids are lentic species, collected frequently in ponds and lakes, whereas naidids are found in riffles. The ratio of tubificids to naidids equaled 1.52 and 0.07 in pools and riffles, respectively. Among uncommon species, this inter-habitat difference was also notable. Ten species of naidids were obtained from riffles but not pools, whereas three species of naidids were found in pools but not riffles. Three species of tubificids were found in pools but not riffles, and only one species of tubificid (Limnodrilus rubripenis) was found only in riffles.

44. The particular combination of species occurring at a given site (especially on a particular date) was generally consistent with, but not identical to, the pool or riffle communities indicated by the composite data summarized in Table 5. Intersite comparisons of chironomid and oligochaete species composition were made using Jaccard's similarity index of beta diversity. Beta diversity is essentially a measure of how different sites are in terms of the variety of species found in them (Magurran 1988). Jaccard's index of beta diversity is equal to $\mathrm{j} /(\mathrm{a}+\mathrm{b}-\mathrm{j})$; where $\underline{\mathrm{a}}$ and $\underline{\mathrm{b}}$ equal the number of species in sites $\underline{a}$ and $\underline{b}$, respectively, and $\mathfrak{j}$ equals the number of species found in both sites. Intersite similarity was low, as exemplified by comparisons among sites in the fall of 1987 (Table 5). The highest observed value was only 0.65 for chironomids at the site 2 riffle versus the site 3 . These results indicate that species composition varies among pools and riffles, although the degree of dissimilarity is probably overestimated due to the low abundance of most species (Figures $9 \mathrm{a}-9 \mathrm{~d}$ ) and the uncertainty of even the presence or absence of such species based on anything less than extremely extensive sampling.

45. Community composition at the species level also varied greatly among sampling dates. For example, although Nais pardalis was the most abundant oligochaete in riffles based on all data combined, this species did not occur in the fall 1988, the spring 1989, or the fall 1989 samples.

46. Only by combining data for all pools and all riffles for all sampling dates are characteristic interhabitat differences evident (Table 5). For example, rheophilic (flow-loving) chironomids that dominated the combined data set for riffles (Thienemanniella nr. fusca, Cricotopus bicinctus, Polypedilum convictum, and Rheotanytarsus sp. as shown in Table 3 did not occur in the same relative abundance on each riffle on a particular date or in similar abundance in a particular riffle on different dates. In addition, although 
Table 5

Community Comparisons (Jaccard's Index) for Chironomids and

Oligochaetes in Luxapalila Creek. Mississippi, 1987-89

\begin{tabular}{llccc}
\hline \multirow{2}{*}{ Taxonomic Group } & Habitat & \multicolumn{3}{c}{ Comparison Between Sites } \\
\cline { 4 - 5 } Chironomidae & Pool & 1 vs 2 & $\underline{2 \text { vs } 3}$ & $\frac{1 \text { vs } 3}{3}$ \\
Oligochaeta & Riffle & 0.55 & 0.63 & 0.41 \\
& Pool & 0.59 & 0.65 & 0.61 \\
& Riffle & 0.31 & 0.23 & 0.43 \\
& 0.35 & 0.35 & 0.36
\end{tabular}

naidids generally dominated the oligochaete community in riffles, species composition of this group exhibited great variation among sites and dates. In general, dynamic changes in species composition even among dominants were generally so great that they masked seasonal patterns of density change that were evident at the family level of description.

47. In June 1988,20 specimens of the oligochaete Piquetiella michiganensis were found in four of five samples of the riffle at site 4. Densities were estimated at 314.3 ( \pm 258.2) individuals/sq $\mathrm{m}$. In a nearby pool two of five core samples yielded one specimen each with an estimated density of 31.4 ( \pm 38.5) individuals per sq $\mathrm{m}$. Similar sampling at two pools and two riffles in Luxapalila Creek near its confluence with the Tombigbee River yielded no $P$. michiganensis. In the fall of 1988, a single $P$. michiganensis was collected in a riffle in the upper section of the lower reach. 48. This species has been reported in north central North America as far south as Virginia (Brinkhurst 1986). It has been collected in the Great Lakes and upper Mississippi River east to the Susquehanna and Chemung Rivers in New York (Hiltunen and Klemm 1980; Klemm 1985), and south to the Wabash River in southern Indiana.* More complete macroinvertebrate surveys in the central United States would establish whether the apparent disjunct distribution of this species is the result of incomplete data or specific habitat requirements that are occasionally met at the periphery of its range.

* Personal Communication, Feb 1989, Dr. Michael S. Loden, Jefferson Parish Environmental Department, Jefferson, LA. 
PART IV: DISCUSSION

\section{Major Findings}

49. In this macroinvertebrate study in Luxapalila Creek, samples were taken after exceptionally high (June and November 1989) and low (June and September 1988) water. Floods and droughts are physical factors of potentially major significance to the structure and abundance of stream invertebrate communities. Intersite and interdate variability in community structure were probably intensified by the extreme range of physical conditions that occurred during this study. This factor was mainly responsible for the high biological diversity in Luxapalila Creek. In addition, the high equitability of species within chironomid and oligochaete communities reflected effects of a wide range of extreme physical conditions that occurred between September 1987 and November 1989.

50. Especially low densities of chironomids, oligochaetes, and total invertebrates were prominent characteristics of Luxapalila Creek in June 1989, although each site did not exhibit reduced density of all three groups. It is noteworthy that the highest mean daily discharge (14,000 cfs) recorded during the course of this study occurred in January 1989. The prominence of especially low densities in June 1989 is evidence that scouring floods affected standing crops (although to different degrees for particular taxa at particular sites). By November 1989, oligochaetes at site 4 (the only site sampled in the fall of 1989) had not recovered in the pool or riffle, but chironomids in pool 4 were at the highest average density observed for this group of invertebrates in Luxapalila Creek pools (Figure 6a). Midges are notable for their ability to rapidly recolonize after decimation, with their aerial adult stage and the aquatic drift of larvae contributing to this opportunistic characteristic (e.g., Simpson and Bode 1980). Oligochaetes are of course fully aquatic; naidids can enter the drift although tubificids rarely do (Milbrink 1973). During early biological colonization of a manmade gravel bar in the Tennessee-Tombigbee Waterway, chironomids were among the first colonists while oligochaetes appeared later (Bingham and Miller 1989).

51. In addition to scouring high flows during the winter and spring of 1989, this study included a period of sustained and exceptionally low water during the summer and fall of 1988. The lowest recorded discharge (25 cfs) in the 16-year history of records was measured during the summer of 1988 . The 
abundance of Paracladopelma undine, a dominant chironomid in pools, declined greatly in the fall of 1988, from initially high densities in the fall of 1987 and spring of 1988. Paracladopelma undine is a member of a genus that is apparently restricted to cool water (Wierderholm 1983). It is possible that the decline of this species in the fall of 1988 may have been related to physical stress (such as reduced dissolved oxygen and increased water temperature) associated with extremely low stream discharge for a sustained period. Similarly, it is noteworthy that the highest measured ratio (5.0) of tubificid to naidid oligochaetes on any date was measured for the October 1988 pool samples. Tubificids are recognized to be tolerant of pool water quality, including low dissolved oxygen and high temperature (Brinkhurst and Cook 1974).

52. Ordinarily, cumulative species is a linear function of the logarithm of the cumulative number of individuals (e.g., McNaughton and Wolf 1973). The lack of a semilogarithmic relationship between cumulative species and cumulative individuals (Figure 8 ) during this study was primarily because even more species of chironomids and oligochaetes are likely to occur in Luxapalila Creek than were identified. Nonetheless, the extreme physical conditions of both low and high flow allowed more species per individuals identified to be accounted for than if more stable discharge conditions had prevailed.

53. The slopes of dominance-diversity plots of chironomid and oligochaete communities (Figures 9a-9d) were extraordinarily low and indicate the high equitability of species in Luxapalila Creek. Percentage abundance of species changed only two orders of magnitude in community samples of 27 63 species. Generally, a range in species abundance of 3 to 5 orders of magnitude would be associated with rich assemblages of species (McNaughton and Wolf 1973; Whittaker 1965). In comparison, species abundances of 15-30 species in samples of riverine mussel communities typically span the same range as that observed among 27-63 species of chironomids or oligochaetes in Luxapalila Creek. The high equitability among species of chironomids and oligochaetes in Luxapalila Creek pools and riffles observed during the present study may have been 'enhanced by the extreme range of hydraulic conditions. 


\section{Recommendations}

54. Choice of sites within the project area for a post-construction macroinvertebrate study should include at least one pool-riffle sequence not directly affected and one pool-riffle sequence directly affected by the project. Pools directly affected by construction may become more depositional in nature than pools not directly affected by construction. Thus; poolversus-riffle comparisons at locations directly affected by the project may show clearer differences in macroinvertebrate community structure than poolversus-riffle comparisons at locations not directly affected by the project. As in the present study, characterizations of the macroinvertebrate community should focus on density and species relative abundance. Macroinvertebrates should be studied at the pool and riffles of site 4, because this site is upstream of the project area and is not likely to show direct or indirect effects of project construction. 
Arner, D. H., Robinette, H. R., Frasier, J. E., and Gray, M. H. 1976. "Effects of Channelization on the Luxapalila River on Fish, Aquatic Invertebrates, Water Quality, and Furbearers," Contract Report No. 14-16-0008-739, Department of Wildlife and Fisheries, Mississippi State University.

Bingham, C. R., and Miller, A. C. 1989. "Colonization of a Man-Made Gravel Bar by Oligochaete," Hydrobiologia, Vol 180, pp 229-234.

Brinkhurst, R. O. 1986. "Guide to the Freshwater Aquatic Microdrile Oligochaetes of North America," Canadian Special Publication of Aquatic Sciences 84, Department of Fisheries and Oceans, Ottawa, Canada.

Brinkhurst, R. O., and Cook, D. G. 1974. "Aquatic Earthworms (Annelida: Oligochaeta)," Pollution Ecology of Freshwater Invertebrates, C. W. Hart, Jr., and S. L. H. Fuller, eds., Academic Press, New York and London.

Hiltunen, J. K., and Klemm, D. J. 1980. "A Guide to the Naididae (Annelida: Clitellata: Oligochaeta) of North America," EPA-6000/4-80-031, Environmental Monitoring and Support Laboratory, Cincinnati, $\mathrm{OH}$.

Hynes, H. B. N. 1970. "The Ecology of Running Waters," University of Toronto Press, Toronto, Canada.

King, R. H., Miller, A. C., and Glover, J. E. 1982. "Proposed Riffle Construction in an 01d River Channel, " Journal of the Mississippi Academy of Sciences, Vol 27, pp 151-161.

Klemm, D. J. 1985. "A Guide to the Freshwater Annelida (Polychaeta, Naidid and Tubificid Oligochaeta, and Hirudinea) of North America, Kendall/Hunt Publishing Company, Dubuque, IA.

Magurran, A. E. 1988. "Ecological Diversity and its Measurement," Princeton University Press, Princeton, NJ.

McNaughton, S. J., and Wolf, L. L. 1973. General Ecology, Holt, Rinehart, and Winston, Inc., New York.

Milbrink, G. 1973. "On the Vertical Distribution of Oligochaetes in Lake Sediments," Report No. 53, Institute of Freshwater Research, Drottingholm.

Miller, A. C., and Bingham, C. R. 1987. "A Hand-held Benthic Core Sampler," Journal of Freshwater Ecology, Vol 4, pp 77-81.

Miller, A. C. 1987. "Habitat Development in Navigable Waterways Using Dredged Material, " Proceedings of the Twenty-first Annual Dredging Seminar. John B. Herbich, ed., Texas Engineering Experiment Station, Texas A\&M University, College Station, TX, pp 2-12.

Russel1-Hunter, W. D. 1970. "Aquatic Productivity: An Introduction to Some Basic Aspects of Biological Oceanography and Limnology," MacMillan Publishing Co., New York.

Shields, F. 1983. "Design of Habitat Structures for Open Channels," Journal of Water Resources Planning Management. Vol 109, pp 331-344.

Simpson, E. H. 1949. "Measurement of Diversity," Nature, Vol 163, p 688.

Simpson, K. W., and Bode, R. W. 1980. "Common Larvae of Chironomidae

(Diptera) from New York State Streams and Rivers," Bulletin No. 439, New York State Museum, New York. 
Standford, J. A., and Ward, J. V. 1979. "Stream Regulation in North America," The Ecology of Regulated Streams, J. V. Ward and J. A. Standford, eds., Plenum Press, New York, pp 215-236.

Tharpe, E. J., Plunkett, M. L., Morris, F., and Oakley, W. T. 1987. "Water Resources Data--Mississippi Water Year 1987," US Geological Survey Water-Data Report MS-87-1, Jackson, MS.

US Army Corps of Engineers. 1986. "Environmental Description of Luxapalila Creek, Mississippi and Alabama," US Army Engineer District, Mobile, AL.

US Fish and Wildlife Service. 1987. "Supplementary Report to the Final Fish and Wildlife Coordination Act Report on Luxapalila Creek," US Fish and Wildlife Service, Daphne, AL.

US Soil Conservation Service. 1971a. "Guidelines for Planning and Review of Channe1 Improvements," US Soil Conservation Service Watershed Memorandum 108. . 1971b. "Planning and Design of Open Channels," US Soil Conservation Service Technical Report 25.

Whittaker, R. H. 1965. "Dominance and Diversity in Land Plant Communities," Science, Vol 147, pp 250-260.

Wiederholm, T., ed. 1983. "Chironomidae of the Holarctic Region. Keys and Diagnoses; Part I. Larvae," Entomological Scandinavica, Supplement 19.

Woods, L. C., III, and Griswold, B. L. 1981. "Channelization and Mitigation: Their Effects on Macroinvertebrate Communities in the Olentangyi River, Columbus, Ohio," Warmwater Streams Symposium of the American Fisheries Society.

L. A. Krunholz, ed., Lawrence, KS, pp 113-118. 
APPENDIX A

COUNTS OF MAJOR TAXA PER CORE SAMPLE, FALL 1987. 


\begin{tabular}{|c|c|c|c|c|c|c|c|c|c|c|c|c|c|c|c|c|c|}
\hline Luxapolila Creek, Mississippi & & & & & & & & & & & & & & & & & \\
\hline Sampling Date: $9 / 16 / 87$ & & & & & & & & & & & & & & & & & \\
\hline LX987C & & & & & & & & & & & & & & & & & \\
\hline Counts of major taxa: raw dat & & & & & & & & & & & & & & & & & \\
\hline (for those semples identifiec & d to species, & counts & are summ & led here, & all other & ers $(*)$ are $r \varepsilon$ & an data) & & & & & & & & & & \\
\hline & & & & & & & & & & & & & & & & & \\
\hline & 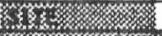 & & & & & & & & & & & & & & & & \\
\hline Maris & 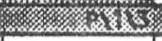 & 经 & - & PXIY) & PrTito: & PXax & 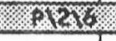 & Wrat & PXET: & $8 \times 2 X 10$ & maxix & 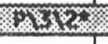 & 20 & 2xis & res & aror & exson \\
\hline & & & & & & & & & & & & 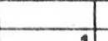 & 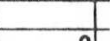 & 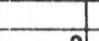 & - & & \\
\hline Turbellaria & 0 & 0 & 0 & 0 & 0 & 0 & 1 & 0 & 0 & 0 & 0 & 1 & 0 & 0 & 1 & 0 & 0 \\
\hline ol igochoeta & 14 & 9 & 7 & 18 & 6 & 14 & 59 & 31 & 8 & 31 & 8 & 14 & 16 & 11 & 27 & 30 & 18 \\
\hline Chironomidae & 46 & 22 & 40 & 34 & 17 & 21 & 22 & 58 & 35 & 61 & 12 & 31 & 23 & 9 & 24 & 8 & 1 \\
\hline Ceratopogonid & 0 & o & 6 & 2 & 3 & 0 & 0 & 5 & 1 & 3 & 0 & 0 & 1 & 0 & 2 & 0 & 3 \\
\hline Coleoptera & & of & o & 1 & 0 & 0 & 1 & 0 & 0 & 2 & 0 & 0 & 2 & 0 & 0 & 1 & 0 \\
\hline Ephemeroptera & 0 & 0 & 0 & 0 & 0 & 0 & 0 & 0 & 0 & 0 & 0 & 0 & 0 & 0 & 0 & 0 & 0 \\
\hline Odonata & 0 & 1 & 0 & 0 & 0 & 0 & 0 & 1 & 0 & 0 & 0 & 0 & 0 & 0 & 0 & 0 & 0 \\
\hline Plecoptera & 0 & 0 & 0 & 0 & 0 & 0 & 0 & 0 & 0 & 0 & 0 & 0 & 0 & 0 & 0 & 0 & 0 \\
\hline Trichoptera & 1 & 0 & 0 & 0 & 0 & 0 & 2 & 1 & 0 & 2 & 0 & 0 & 0 & 0 & 0 & 0 & 0 \\
\hline Amphipoda & 1 & 0 & 1 & 0 & 0 & 0 & 0 & 0 & 0 & 0 & & 0 & 0 & 0 & 0 & 0 & 0 \\
\hline I sopoda & 0 & 3 & 0 & 0 & 0 & 0 & 0 & 0 & 0 & 0 & & 0 & 0 & 0 & 0 & 0 & 0 \\
\hline Bivalvia & 2 & 5 & 1 & 1 & 0 & 13 & 10 & 28 & 17 & 21 & & 2 & 3 & 0 & 1 & 0 & 1 \\
\hline Gastropoda & 2 & 0 & 0 & 0 & 0 & 1 & 0 & 0 & 1 & 1 & 0 & 0 & 0 & 6 & 0 & 0 & 1 \\
\hline & & & & & & & & & & & & & & & T & & \\
\hline MiNoR RROHSS & & & & & & & & & & & & & & & & & \\
\hline Acarina & 5 & 0 & 7 & 0 & 1 & 2 & 1 & 11 & 0 & 1 & & 0 & 0 & 2 & 7 & 2 & 0 \\
\hline Polychaeta & 0 & 0 & 0 & 0 & 0 & 0 & 0 & 1 & 0 & 0 & 0 & 0 & 1 & 0 & 0 & 0 & 0 \\
\hline Hirudínee & 0 & 0 & 0 & 0 & 0 & 0 & 0 & 1 & 0 & 0 & 0 & 0 & 0 & 0 & 9 & 0 & 1 \\
\hline Empididae & 0 & 0 & 0 & 0 & 0 & 0 & 0 & 0 & 0 & 0 & T & 0 & 0 & 0 & 0 & 0 & 0 \\
\hline Collembole & 1 & 0 & 0 & 0 & 0 & 0 & 0 & 0 & 0 & 0 & 0 & 1 & 0 & 0 & 0 & 0 & 0 \\
\hline Nematodo & 20 & 8 & 17 & 10 & 3 & 2 & 2 & 8 & 4 & 9 & 3 & 1 & 19 & 10 & 0 & 4 & 3 \\
\hline Nemertea & 0 & 0 & 0 & 3 & 0 & 0 & 0 & 0 & 0 & 0 & 0 & 0 & 0 & 0 & 24 & 0 & 0 \\
\hline Aeolosomat idae & 0 & 0 & 0 & 0 & 0 & 0 & 0 & 0 & 0 & 0 & & 0 & 0 & 0 & 0 & 0 & 0 \\
\hline & & & & & & & & & 1 & & & & 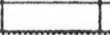 & T & 7 & 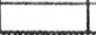 & \\
\hline Tol & 20 & 6 & (x) & 69. & 30 & 53 & 89. & 1145 & 56 & 131 & 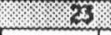 & 50 & 6 & 38 & 37 & (3) & 28 \\
\hline & & & & & & & & & & & & & & & & & \\
\hline & & & & & & & & & & & & & & & & & \\
\hline & & & & & & & & & & & & & & & & & \\
\hline & & & & & & & & & & & & & & & & & \\
\hline
\end{tabular}




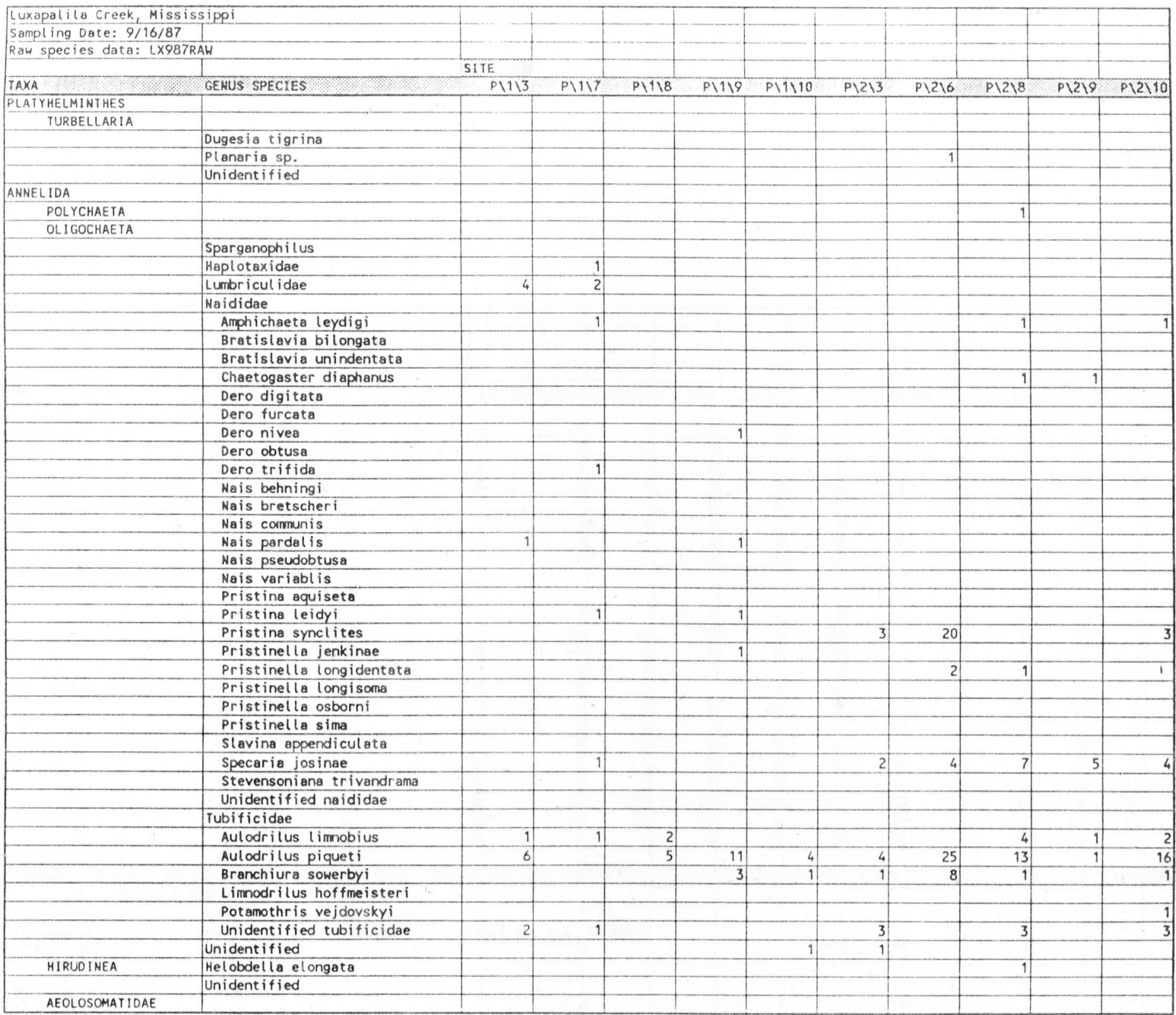




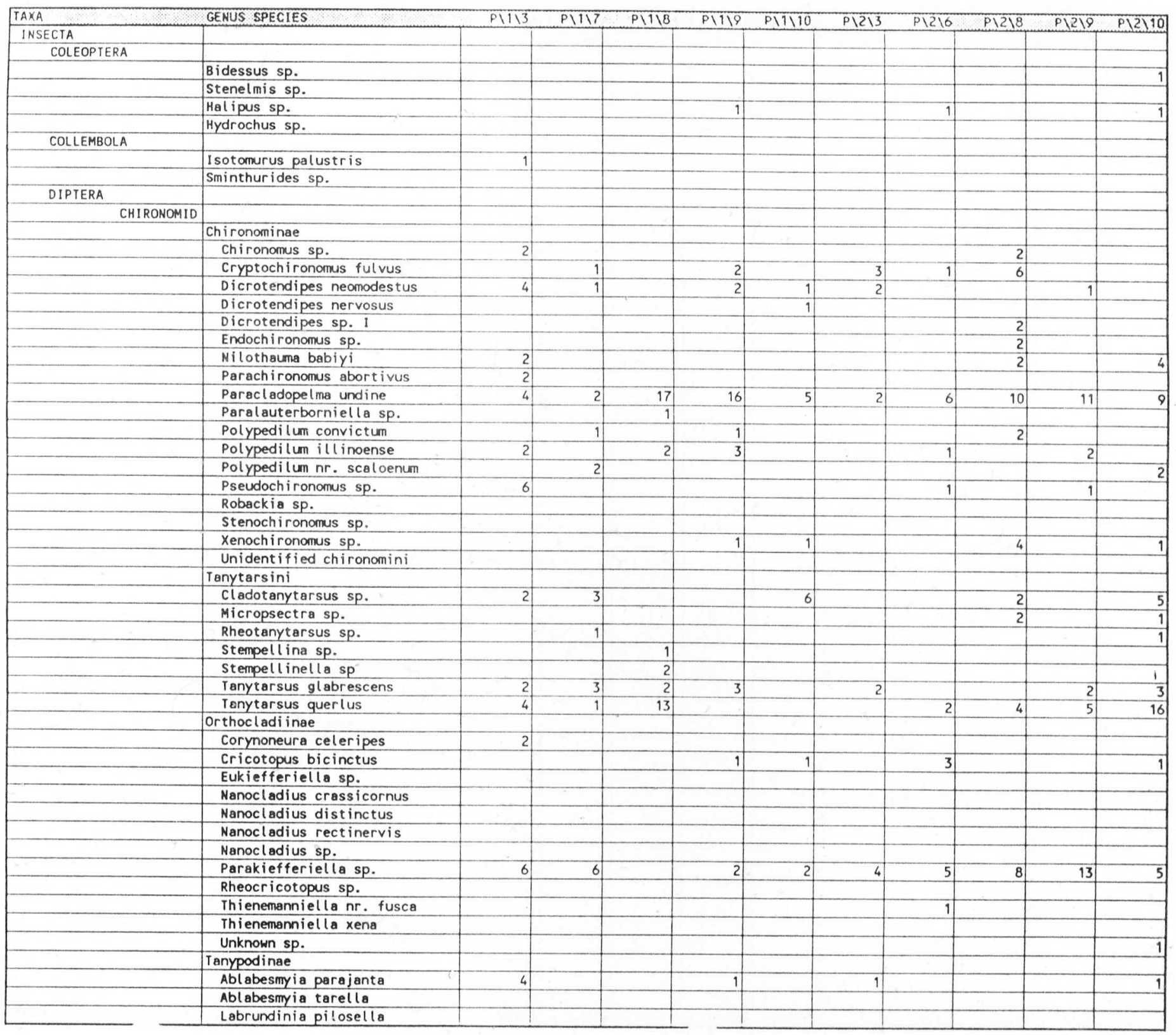




\begin{tabular}{|c|c|c|c|c|c|c|c|c|c|c|c|}
\hline TAXA & GENUS SPECIES & $p 1113$ & P 1117 & $p+118$ & PाI & P17110 & P1213 & $P 1216$ & $P 1218$ & PI2\9 & P(2)10] \\
\hline & Macropelopia sp. & 2 & & & & & -1 & 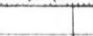 & & & \\
\hline & Nilotanypus sp. & & & & & & 1. & & & & \\
\hline & Pentaneura sp. & & & 1 & & & & & & & \\
\hline & Procladius sp. & & & & & & 3 & 1 & 4 & & 2 \\
\hline & Unidentified tanypodinae & 2 & & 1 & 1 & & 2 & 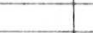 & 2 & & \\
\hline & Unidentified & & 1 & 1 & 1 & & 1 & 1 & 6 & & 9 \\
\hline & Ceratopogonidae & & & & & & & & 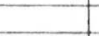 & & \\
\hline & Alluaudomyia sp. & & & 4 & 2 & 3 & & & 1 & & \\
\hline & Bezzia sp. & & & 2. & & & & & 4. & 1 & 3 \\
\hline 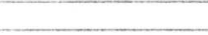 & Empididae & & & & & & & & & & \\
\hline & Hemerodromia & & & & & & & & & & \\
\hline \multicolumn{12}{|c|}{ EPHEMEROPTERA } \\
\hline & Caenis sp. & & & & & & & & & & \\
\hline & Ephemerella sp. & & & & & & & & & & \\
\hline & Tricorythodes sp. & & & & & & & & & & \\
\hline & Cinygmula subaequal is & & & & & & & & & & \\
\hline & Spinadis wallace & & & & & & & & & & \\
\hline & Unknown sp. A (squatty bodies) & & & & & & & & & & \\
\hline & Unknown sp. B (slim guys) & & & & & & & & & & \\
\hline & Unknown sp. c & & & & & & & & & & \\
\hline \multicolumn{12}{|l|}{ ODONATA } \\
\hline & Argia sp. & & & & & & & & & & \\
\hline & Macromia sp. & & & & & & & & 1 & & \\
\hline & Archilestes & & & & & & & & & & \\
\hline & Immatures & & 1 & & & & & & & & \\
\hline \multicolumn{12}{|l|}{ PLECOPTERA } \\
\hline & Perlinella ephyre & & & & & & & & & & \\
\hline & Imnatures & & & & & & & & & & \\
\hline \multicolumn{12}{|l|}{ TRICHOPTERA } \\
\hline & Macronema zebratum & & & & & & & & & & \\
\hline & Unknown hydropsychid sp. & & & & & & & & & & \\
\hline & Hydroptile sp. & & & & & & & & & & \\
\hline & oecetis sp. & 1 & & & & & & 1 & & & \\
\hline & Chimarra sp. & & & & & & & & 1) & & \\
\hline & Polycentropus sp. & & & & & & & 1 & & & 2 \\
\hline & Lype diversa & & & & & & & & & & \\
\hline & Unidentified & & & & & & & & & & \\
\hline \multicolumn{12}{|l|}{ AMPHIPODA } \\
\hline & Synurella sp. & 1 & & 1 & & & & & & & \\
\hline \multicolumn{12}{|l|}{ ISOPODA } \\
\hline & Asellus sp. & & 3 & & & & & & & & \\
\hline ACARINA & & 5 & & 7 & & 1 & 2 & 1 & 19 & & 1 \\
\hline \multicolumn{12}{|l|}{ MOLLUSCA } \\
\hline PELECYPOOA & Corbicula fluminea & 2 & 5 & 1 & 1 & & 13 & 10 & 28 & 17 & 21 \\
\hline \multirow[t]{4}{*}{ GASIROPOOA } & Ferrissia rivularis & 2. & & & & & & & & 1) & 1 \\
\hline & Amnicola sp. & & & & & & & & & & \\
\hline & Gyraulus sp. & & & & & & & & & & \\
\hline & Unidentified & & & & & & 1 & & & & \\
\hline \multicolumn{12}{|l|}{ OTHER } \\
\hline NEMATOOA & & 20 & 8 & 17 & 10 & 3 & 2 & 2 & 8 & 4 & 9 \\
\hline \multicolumn{12}{|l|}{ NEMERTEA } \\
\hline & Prostoma graecense & & & & 3 & & & & & & \\
\hline & & & & & & & & & & & \\
\hline TOTALS & 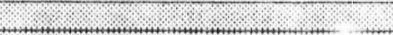 & 92 & 48 & 79 & 69 & 30 & 53 & 98 & 145 & 66. & 131 \\
\hline SPECIES NLMBER & & 27 & 23 & 17 & 23 & 13 & 20 & 22 & 32 & 15 & 31 \\
\hline
\end{tabular}




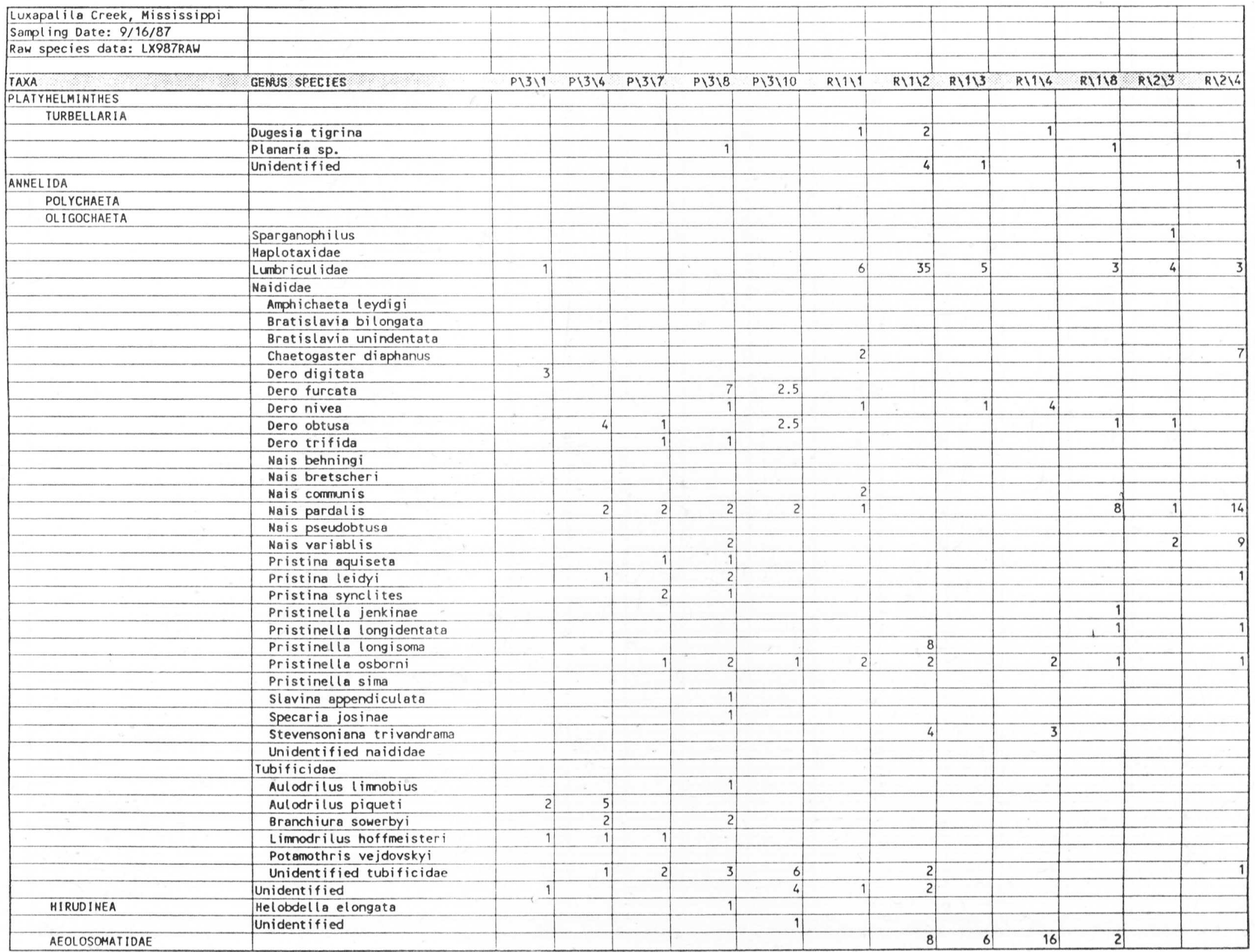




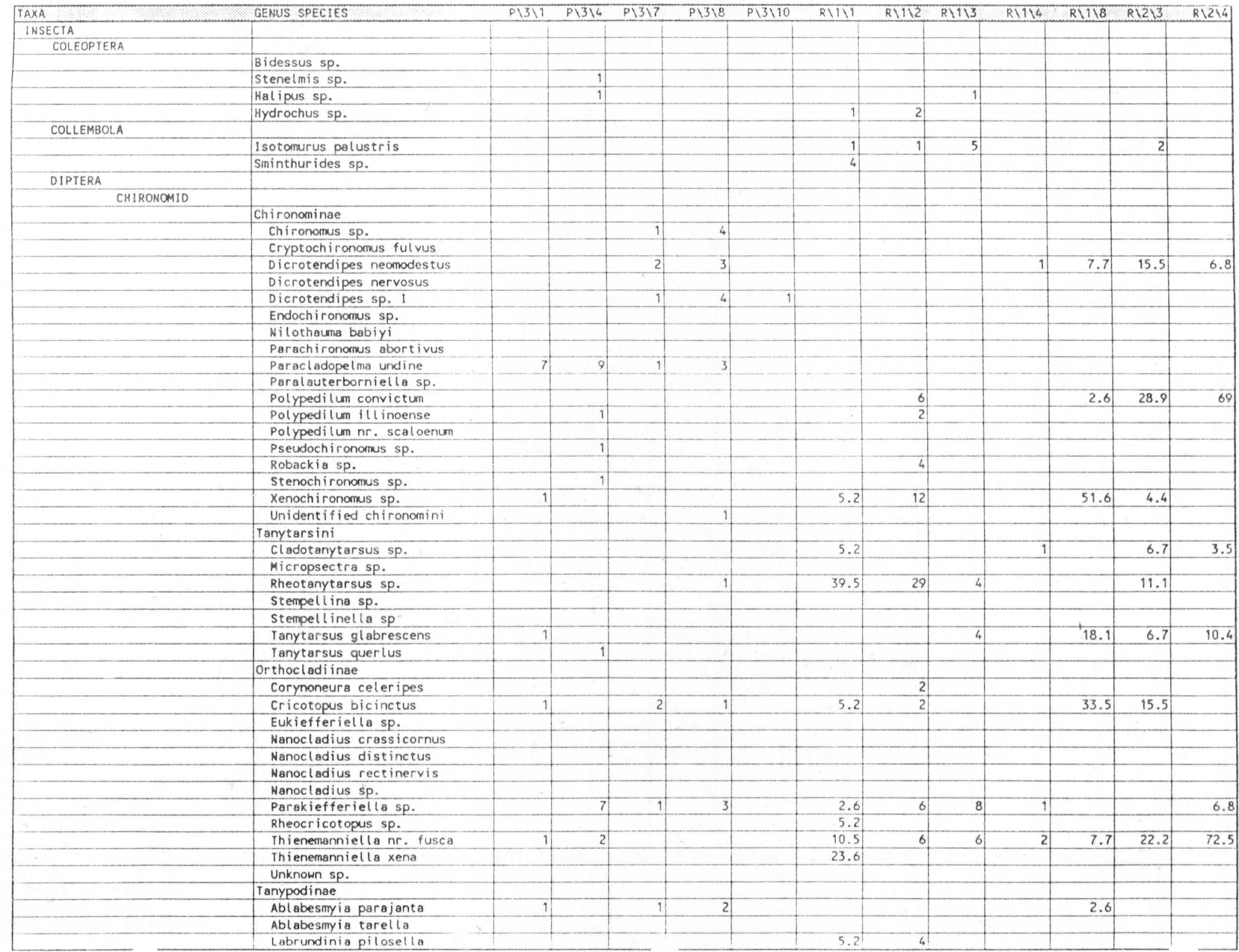




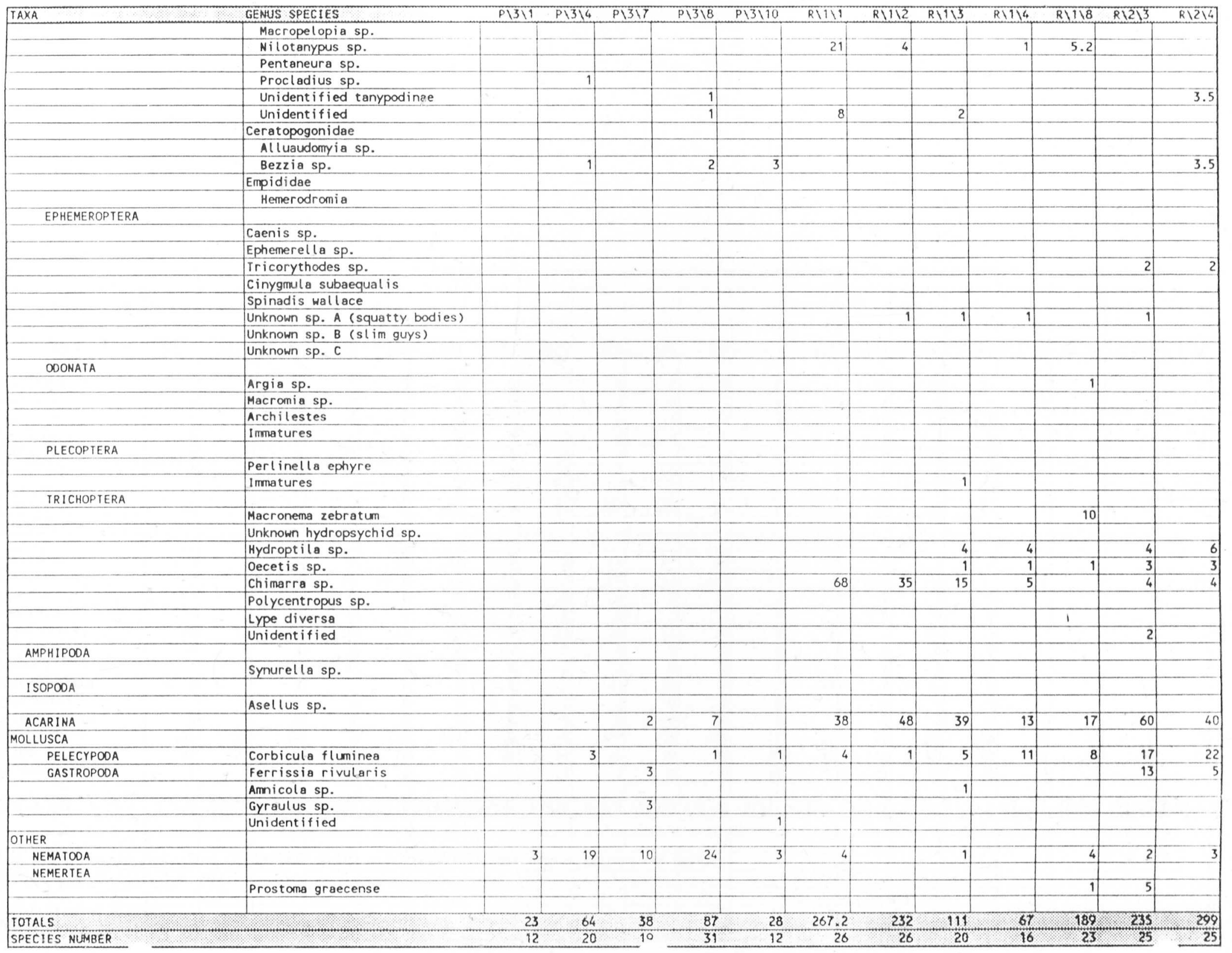




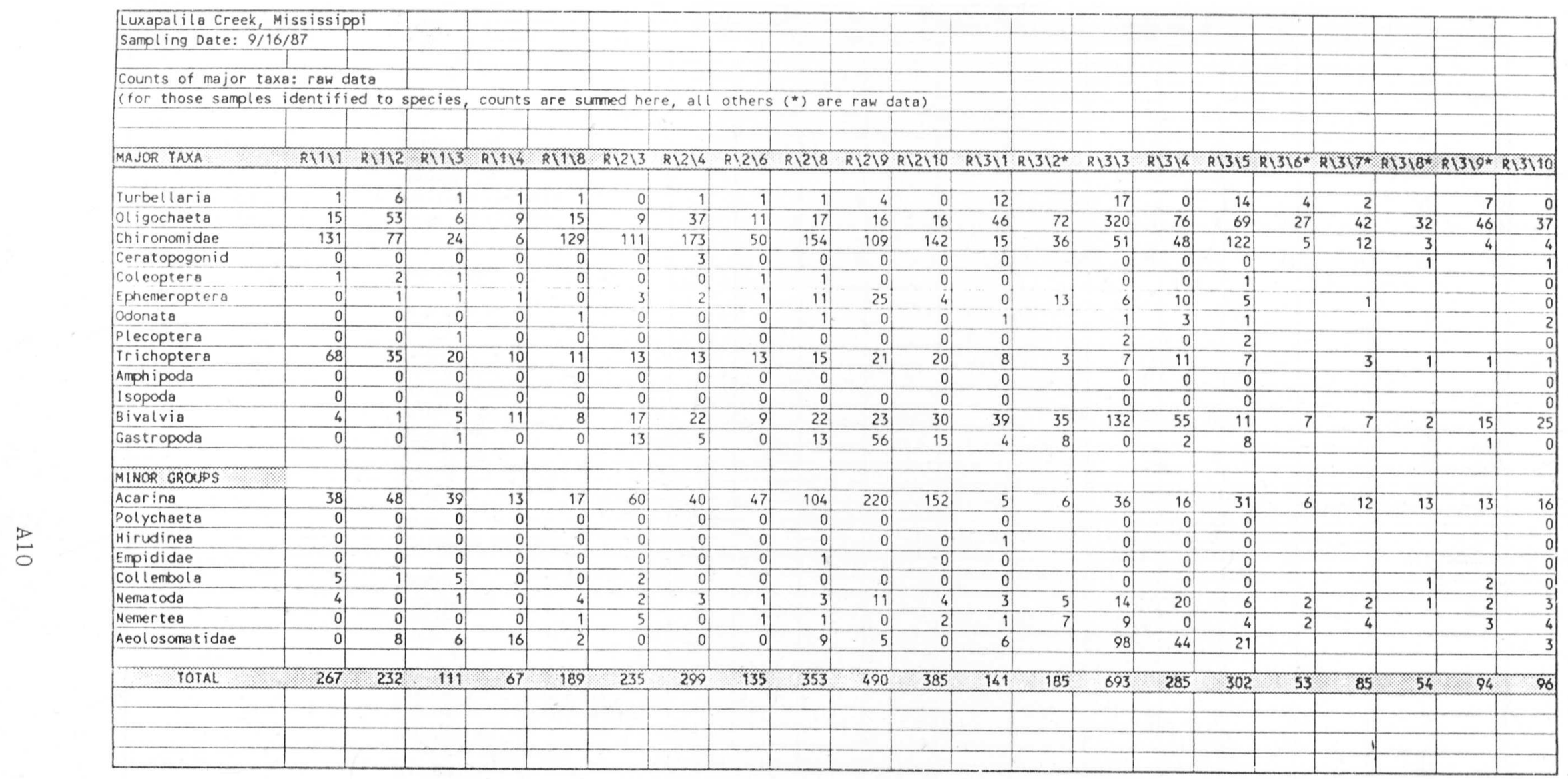




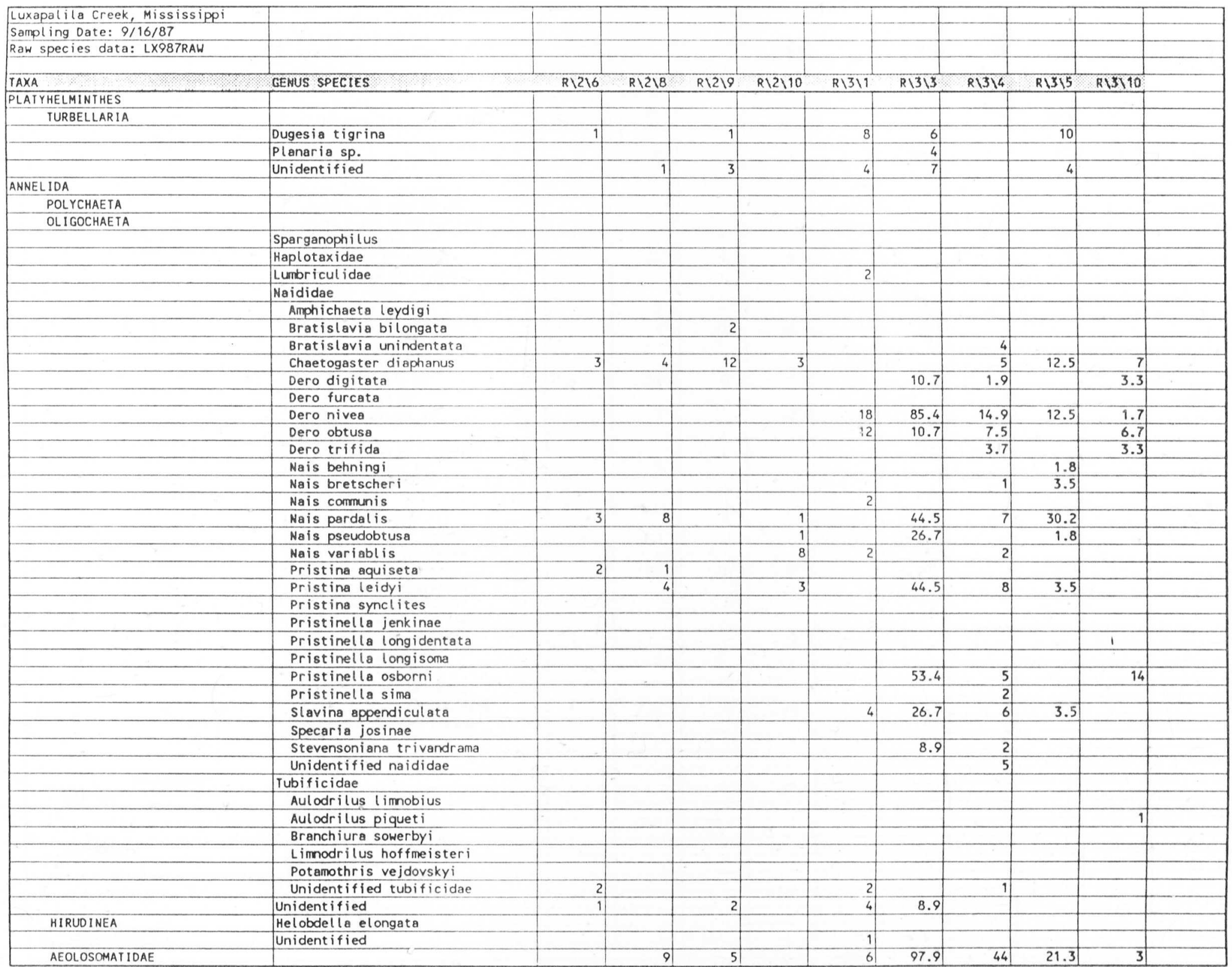




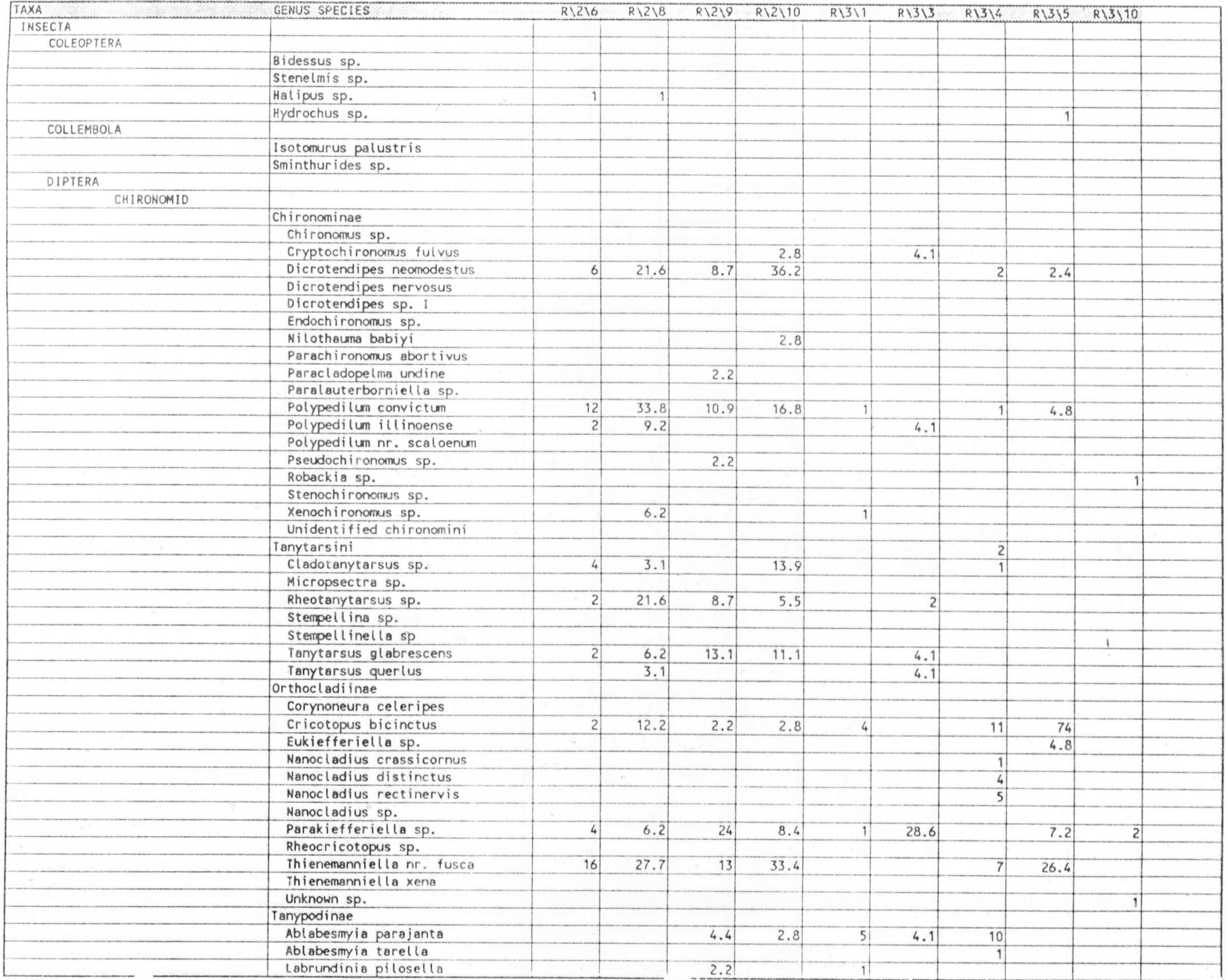




\begin{tabular}{|c|c|c|c|c|c|c|c|c|c|c|c|}
\hline TAXA & GENUS SPECIES & $R \backslash 216$ & $R \backslash 218$ & $R 1219$ & $R \backslash 2 \backslash 10$ & $R \backslash 3 \backslash 1$ & $R 1313$ & 81516 & 8125 & $8 \backslash 3 \backslash 10$ & \\
\hline & Macropelopia sp. & & & & & & & $+\mathrm{at}$ & & & \\
\hline & Nilotanypus sp. & & & 6.5 & 5.5 & & & 1 & & & \\
\hline & Pentaneura sp. & & & & & & & & & & \\
\hline & Procladius sp. & & & & & & & 7 & & & \\
\hline & Unidentified tanypodinae & & & & & 1. & & 1] & & & \\
\hline & Unidentified & & 3.1 & 10.9 & & 1 & & 1 & 2.4 & & \\
\hline & Ceratopogonidae & & & & & & & & & & \\
\hline & Alluaudomyia sp. & & & & & & & & & & \\
\hline & Bezzia sp. & & & & & & & & & 1 & \\
\hline & Empididae & & & & & & & & & & \\
\hline & Hemerodromia & & 1. & & & & & & & & \\
\hline EPHEMEROPTER & & & & & & & & t & & & \\
\hline & Caenis sp. & & 1 & & & & & 2 & & & \\
\hline & Ephemerella sp. & & 1 & & & & & 4. & & & \\
\hline & Iricorythodes sp. & 1 & 8 & 14. & & & 5 & 4. & & & \\
\hline & Cinygmula subaequal is & & & 4 & & & & + & & & \\
\hline & Spinadis wallace & & & 3 & & & & & & & \\
\hline & Unknown sp. A (squatty bodies) & & 2 & 4 & 4. & & 1) & 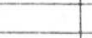 & 2 & & \\
\hline & Unknown sp. B (slim guys) & & & & & & & & 3 & & \\
\hline & Unknown sp. C & & & & & & & & t & & \\
\hline OOONATA & & & & & & & & & & & \\
\hline & Argia sp. & & & & & 1 & & 3 & 1 & & \\
\hline & Macromia sp. & & & & & & & & & 1 & \\
\hline & Archilestes & & 1 & & & & & & & & \\
\hline & Immatures & & & & & & 1 & & & 1 & \\
\hline PLECOPTERA & & & & & & & & & & & \\
\hline & Perlinella ephyre & & & & & & & & 1 & & \\
\hline & Immatures & & & & & & 2 & & 1 & & \\
\hline TRICHOPTERA & & & & & & & & & & & \\
\hline & Macronema zebratum & & & & 1. & & & & 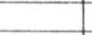 & & \\
\hline & Unknown hydropsychid sp. & & & & & & & & 4 & & \\
\hline & Hydroptila sp. & 2 & 12. & 6 & 8 & & 1 & 3 & 3). & & \\
\hline & Decet is sp. & 2 & 1 & 9. & 3 & 1 & 4 & 3 & 1 & 1 & \\
\hline & Chimarra sp. & 9 & 2 & 6 & 2. & 7. & 2 & & 4 & & \\
\hline & Polycentropus sp. & & & & 6. & & & t & & & \\
\hline & Lype diversa & & & & & & & 5 & & 1 & \\
\hline & Unidentified & & & & & & & & & & \\
\hline AMPHIPOOA & & & & & & & & & & & \\
\hline & synurella sp. & & & & & & & & & & \\
\hline ISOPOOA & & & & & & & & & & & \\
\hline & Asellus sp. & & & & & & & & & & \\
\hline ACARINA & & 47 & 104 & 220 & 152 & 5 & 36 & 16 & 31 & 16 & \\
\hline MOLLUSCA & & & & & & & & & & & \\
\hline PELECYPOOA & Corbicula fluminea & 9 & 22 & 23 & 30 & 39 & 132 & 55 & 11 & 25 & \\
\hline GASTROPODA & Ferrissia rivularis & & 13 & 56 & 15 & 4 & & 2 & 8 & & \\
\hline & Amnicola sp. & & & & & & & & & & \\
\hline & Gyraulus sp. & & & & & & & & & & \\
\hline & Unidentified & & & & & & & & & & \\
\hline OTHER & & & & & & & & & & & \\
\hline NEMATOOA & & 1 & 3. & 11. & 4. & 3. & 14 & 20 & 6 & 3 & \\
\hline NEMERTEA & & & & & & & & & & & \\
\hline & Prostoma graecense & 1 & 1 & & 2. & 1. & 9 & & 4 & 4 & \\
\hline TOTALS & & & & & & & & & & & \\
\hline $\begin{array}{l}\text { TOTALS } \\
\text { SPECIES NEMBER }\end{array}$ & & $\frac{135}{26}$ & $\frac{353}{32}$ & $\frac{490}{30}$ & $\frac{385}{28}$ & $\frac{141}{28}$ & $\frac{693.4}{32}$ & $\frac{285}{42}$ & $\frac{302,6}{31}$ & $\frac{96}{10}$ & \\
\hline
\end{tabular}


APPENDIX B

SPECIES COMPOSITION IN BENTHIC SAMPLES COLLECTED IN THE SPRING OF 1988 


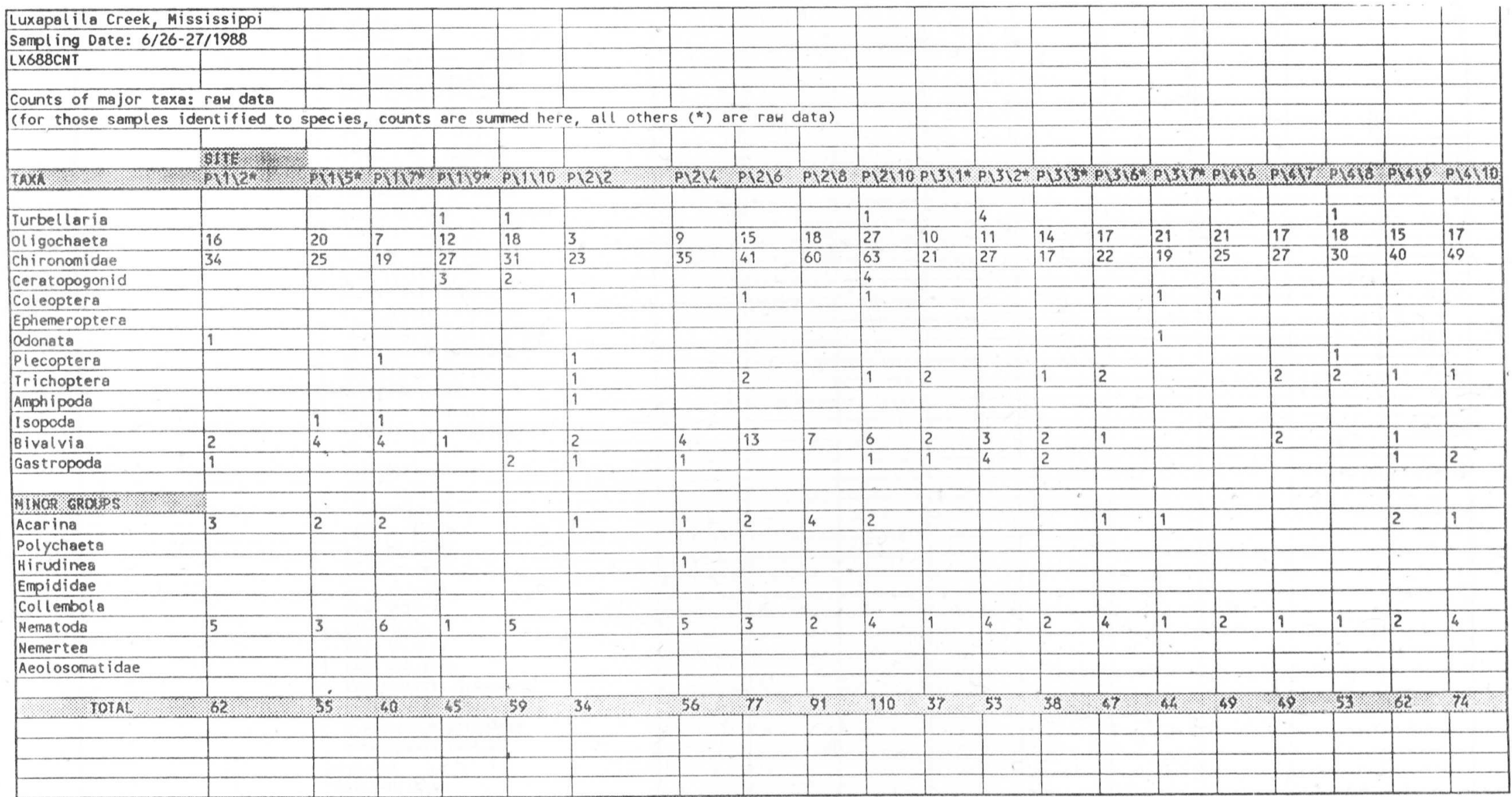




\begin{tabular}{|c|c|c|c|c|c|c|c|c|c|c|}
\hline Luxapalila Creek, Mississipp & & 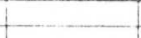 & 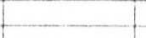 & & & & & & & \\
\hline Sampling Date: $6 / 27-28 / 88$ & & & & & & & & & & \\
\hline Raw species data & & & & & & & & & & \\
\hline 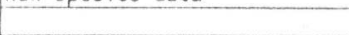 & 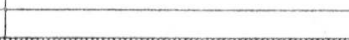 & SITE & & & & & - & & & \\
\hline IAXA & GEMUS SPECIES & P\212 & $P \backslash 216$ & 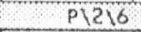 & PI218 & $P \backslash 2 \backslash 10$ & $9 \times 416$ & $P \backslash 4 / 7$ & $p \sqrt{4} \times 8$ & Pर4/9 \\
\hline PLATYHELMINTHES & & & & & & & & & & \\
\hline TURBELLARIA & & & & & & & & & & \\
\hline & Dugesia tigrina & & & & & 1 & & & 1 & \\
\hline & Planaria sp. & & & & & & & & & \\
\hline & Unidentified & & & & & & & & & \\
\hline ANNELIDA & & & & & & & & & & \\
\hline POLYCHAETA & & & & & & & & & & \\
\hline OLIGOCHAETA & & & & & & & & & & \\
\hline & Sparganophilus & & & & & & & & & \\
\hline & Haplotaxidae & & & & & & & & & \\
\hline & Lumbricul idae & & & & & & & 1 & & \\
\hline & Naididae & & & & & & & & & \\
\hline & Amphichaeta leydigi & & 1 & & & & & & & \\
\hline & Bratislavia bilongata & & & & & & & & & \\
\hline & Bratislavia unindentata & & & & & & & & & \\
\hline & Chaetogaster diaphanus & & & 1 & & & & & & \\
\hline & Dero digitata & & & & & & & & & \\
\hline & Dero furcata & & & & & & & & & \\
\hline & Dero nivea & & & & & & & & 5 & \\
\hline & Dero obtusa & & & & 1. & & 1 & & & \\
\hline & Dero trifida & & & & & & & & & \\
\hline & Homochaeta naidina & & & & & & & 1 & & \\
\hline & Nais behningi & & & & & & & & & \\
\hline & Hais bretscheri & & & & & & & & & \\
\hline & Nais communis & & & & & & & & & \\
\hline & Nais pardal is & & & & & & & & & \\
\hline & Nais pseudobtusa & & & & & & & & & \\
\hline & Nais variablis & & & 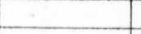 & & & & & & \\
\hline & Piquetiella michiganesis & & & & & & & & & 1 \\
\hline & Pristina aquiseta & & & & & $1]$ & & 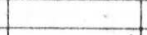 & & \\
\hline & Pristina leidyi & & & & & & & 1 & 1 & \\
\hline & Pristina synclites & & & & & & & & & \\
\hline & Pristinella jenkinae & & & & & & & 1 & & \\
\hline & Pristinella longidentata & & & & & & & & & \\
\hline & Pristinella longisoma & & & & & & & & & \\
\hline & Pristinella osborni & & & & & & & & & 3 \\
\hline & Pristinella sima & & & & & & & & & \\
\hline & Slavina appendiculata & & 1 & & & & & & & \\
\hline & Specaria josinae & 2 & 3. & 2. & 4. & 3 & & 4 & 3. & \\
\hline & Stevensoniana trivandrama & & & & & & & & & \\
\hline & Unidentified naididae & & & & & & & & & \\
\hline & Iubificidae & & & & & & & & & \\
\hline & Aulodrilus limnobius & & & & & & 1 & 4 & & \\
\hline & Aulodrilus piquet $i$ & 1 & & & 1. & 2 & 8 & 3 & 1 & \\
\hline & Aulodrilus pluriseta & & & & & & & & 2 & \\
\hline & Branchiura sowerbyi & & & 1 & & & 1 & & & \\
\hline & Limnodrilus hoffmeisteri & & & & & & 2 & & & \\
\hline & Potamothris vejdovskyi & & & & & & & & & \\
\hline & Unidentified tubificidae & & 3. & 5 & 1) & 3 & 1 & 1 & & 3 \\
\hline- & Unidentified & & & 1 & 1 & 1) & & 3 & 1) & 2 \\
\hline
\end{tabular}




\begin{tabular}{|c|c|c|c|c|c|c|c|c|c|c|}
\hline TAXA & GENUS SPECIES & $P \backslash 212$ & $P 121_{6}^{6}$ & 91216 & $P 1218$ & $P \backslash 2 \backslash 10$ & P1416 & 01417 & 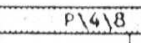 & 9140 \\
\hline \multirow{3}{*}{ HIRUDINEA } & Helobdella elongata & & 1 & & - & & - & & & \\
\hline & Unident ified & & & & & & & & & \\
\hline & & & & & & & & & & 1 \\
\hline \multicolumn{11}{|c|}{ ARTHROPOOA } \\
\hline \multicolumn{11}{|l|}{ INSECTA } \\
\hline \multicolumn{11}{|l|}{ COLEOPIERA } \\
\hline & Bidessus sp. & & & & & & & & & \\
\hline & Stenelmis sp. & & & & & & & & & \\
\hline & Hal ipus sp. & 1 & & 1 & & 1 & 1 & & & \\
\hline & Hydrochus sp. & & & & & & & & & \\
\hline \multicolumn{11}{|l|}{ COLLEMBOLA } \\
\hline & I sotomurus palustris & & & & & & & & & \\
\hline & Sminthurides sp. & & & & & & & & & \\
\hline \multirow{2}{*}{\multicolumn{11}{|c|}{$\begin{array}{l}\text { DIPIERA } \\
\text { CHIRONOMID }\end{array}$}} \\
\hline & & & & & & & & & & \\
\hline & Chironominae & & & & & & & & & \\
\hline & Chironomus sp. & & & & & & 3 & 2 & 1 & 5 \\
\hline & Cryptochironomus fulvus & 3 & 3 & 2. & 5 & 3 & & & 1 & \\
\hline & Dicrotendipes neomodestus & & & & 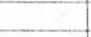 & & 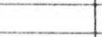 & 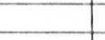 & & 1 \\
\hline & Dicrotendipes nervosus & 1 & 2 & 3 & & & & & & \\
\hline & Dicrotendipes sp. I & & 1 & 1 & 4. & & 1 & & & \\
\hline & Endoch ironomus sp. & & & 1 & 1 & & 3 & 1 & & \\
\hline & Glyptotendipes & 1 & & 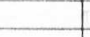 & 1 & 1 & & & 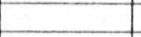 & \\
\hline & Harnischia sp. & & & & 1. & & & & & \\
\hline & Nilothauma babiyi & & & & & & & & 1 & \\
\hline & Parachironomus abortivus & & & & & & & & & \\
\hline & Paracladopelma undine & 6 & 8 & 3 & 7 & 17 & 3 & 8 & 8 & 12 \\
\hline & Paralauterborniella sp. & & & 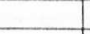 & 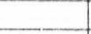 & & & & & \\
\hline & Paratendipes albimanus & & & & & & 1 & & & \\
\hline & Phaenopsectra dyair & & & & & & & & & 1 \\
\hline & Polypedilum convictum & & & & & 2. & & 1 & 1 & \\
\hline & Polypedilum illinoense & & & & & & & & T & \\
\hline & Polypedilum nr. scaloenum & & 1 & 4 & 7 & 3 & 2 & 11 & 3 & 1 \\
\hline & Pseudochironomus sp. & & & 2 & 1 & 1 & & . & 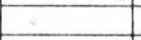 & \\
\hline & Robackia sp. & & & & & & & & 1 & \\
\hline & Stenoch ironomus sp. & & & & & & & & & \\
\hline & Stictoch ironomus sp. & & & & $\therefore$ & & 1 & 1 & & \\
\hline & Xenoch ironornus sp. & & & & & & & & & \\
\hline & Unidentified chironomini & & & & & & & & & \\
\hline & Tanytarsini & & & & & & & & & \\
\hline & Cladotanytarsus sp. & & & & & & & & & \\
\hline & Micropsectra sp. & & & & & & & & & \\
\hline & Rheotanytarsus sp. & & & & & & & & & 1 \\
\hline & Stempellina sp. & & & & 1 & & & & & \\
\hline & Stempellinella sp & & & & & & & & & \\
\hline & Tanytarsus glabrescens & 2 & 5 & 1 & 2 & 2 & & 1 & & 2 \\
\hline & Tanytarsus querlus & 2 & 5 & 11. & 13. & 3 & 2 & 8. & 12 & 7 \\
\hline & Orthocladi inae & & & & & & & & & \\
\hline & Corynoneura celeripes & & & & & & & & & \\
\hline & Corynoneura taris & & & & & & & & & \\
\hline & Cricotopus bicinctus & & & & & & & & & \\
\hline & Eukiefferiello sp. & & & & & & & & & \\
\hline & Nanocladius crassicornus & & & & & & & & & \\
\hline & Nanocladius distinctus & & & & & & & & & \\
\hline
\end{tabular}




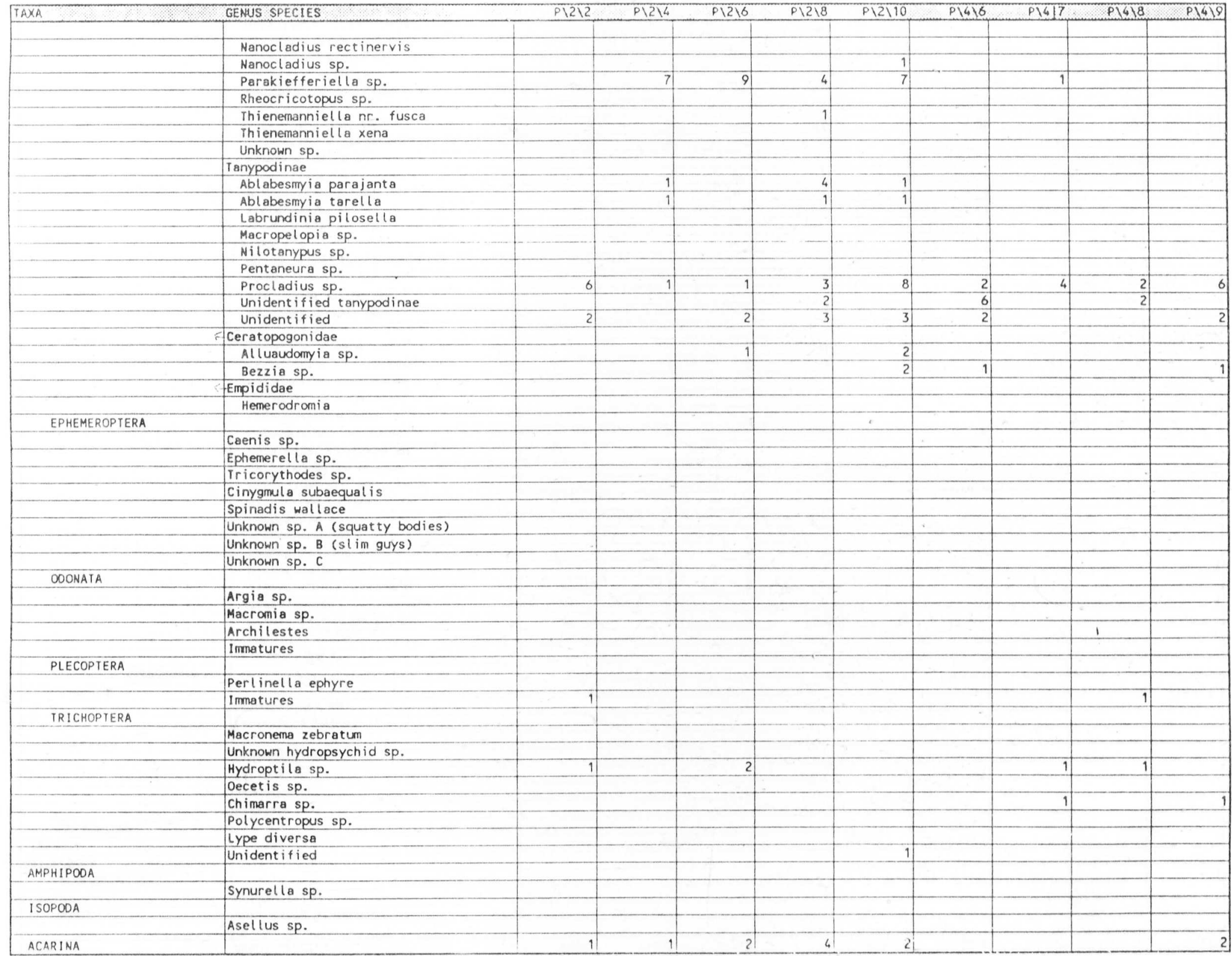




\begin{tabular}{|c|c|c|c|c|c|c|c|c|c|c|}
\hline TAXA & GENUS SPECIES & P\212 & $P \backslash 214$ & $P \backslash 216$ & P1218 & $P \backslash 2 \backslash 10$ & $P 1616$ & $P 14] 7$ & $P \backslash 4) 8$ & $P(4)$ \\
\hline \multicolumn{5}{|l|}{ MOLLUSCA } & & & & & & \\
\hline PELECYPOOA & Corbicula fluminea & 2 & 4 & 13 & 7 & 6 & & 2 & & 1 \\
\hline \multirow[t]{4}{*}{ GASIROPODA } & Ferrissia rivularis & 1 & 1) & & & 1 & & 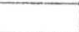 & & 1 \\
\hline & Amnicola sp. & & & & & & & & & \\
\hline & Gyraulus sp. & & & & & & & & & \\
\hline & Unident ified & & & & & & & & & \\
\hline \multicolumn{11}{|l|}{ OTHER } \\
\hline NEMATOOA & & & 5 & 3 & 2 & 4 & 2 & 1 & 1 & 2 \\
\hline \multicolumn{11}{|l|}{ NEMERTEA } \\
\hline & Prostoma graecense & & & & & & & & & \\
\hline & & & & & & & & & & \\
\hline TOTAL NUABER & & 33 & 55 & 71 & 81 & 83 & 46 & 58 & 66 & 8.1 \\
\hline NUMBER OF SPECTES & m, & 16 & 20 & 22 & 25 & 28 & 20 & 22 & 17 & 23 \\
\hline
\end{tabular}




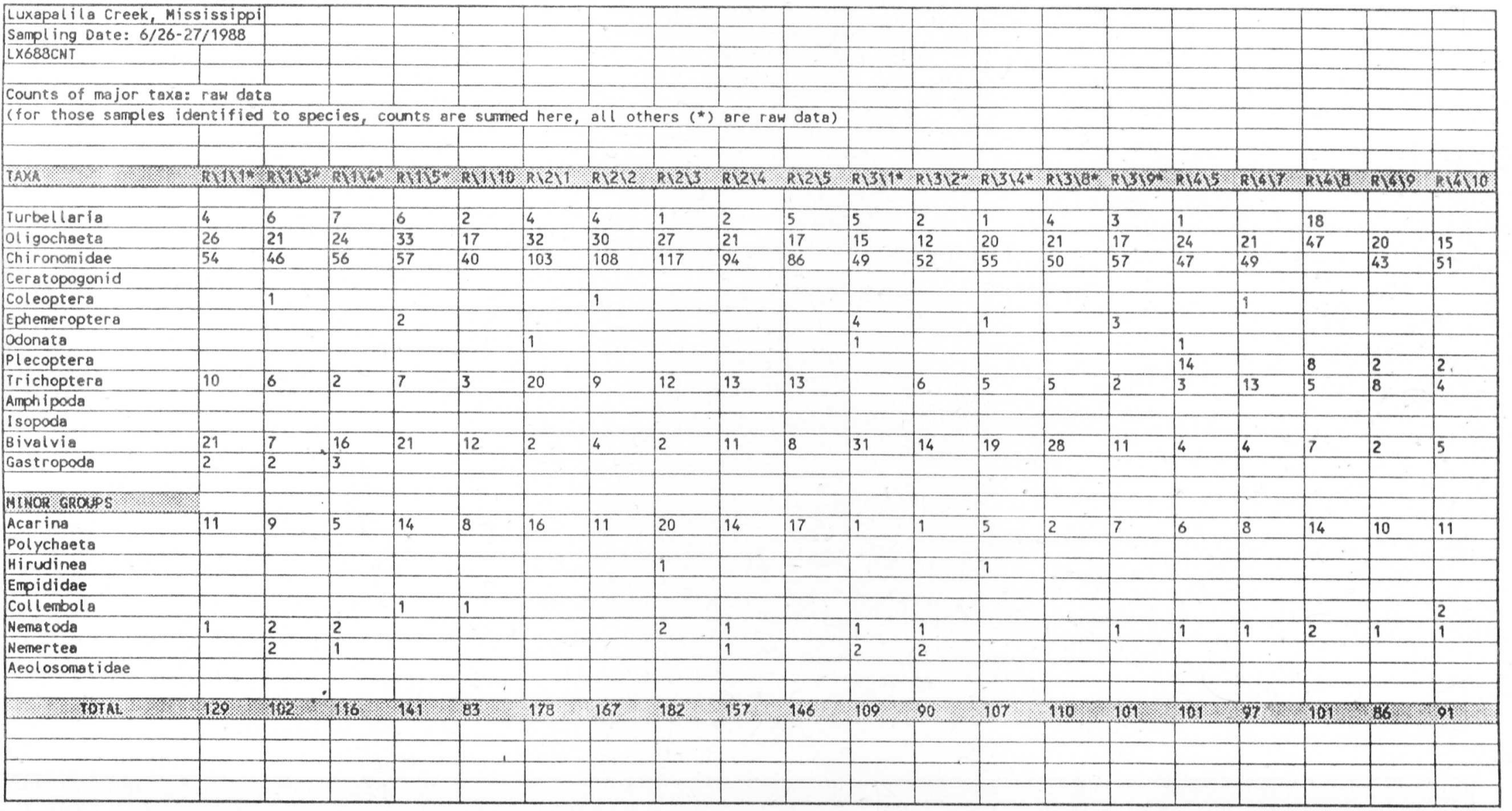




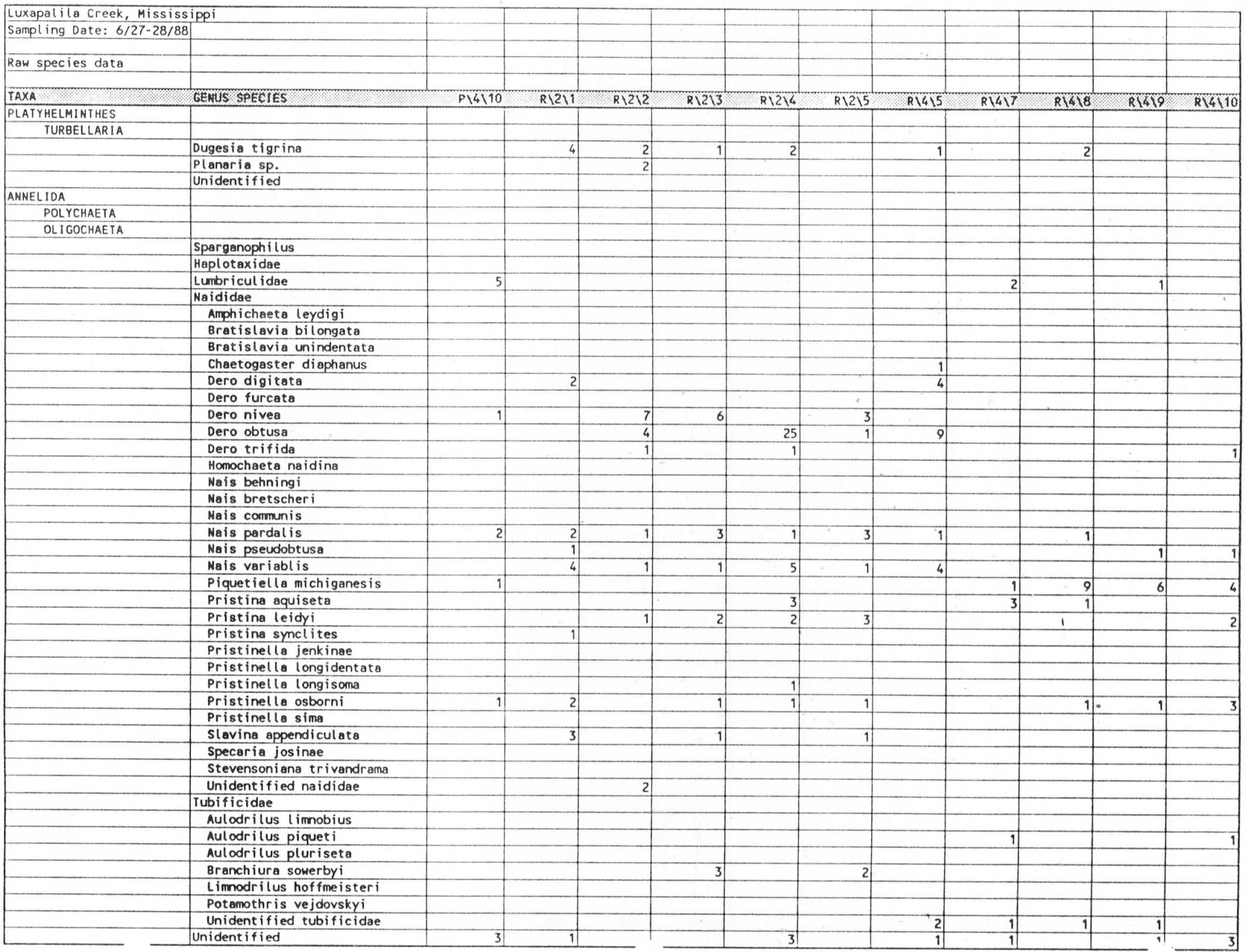




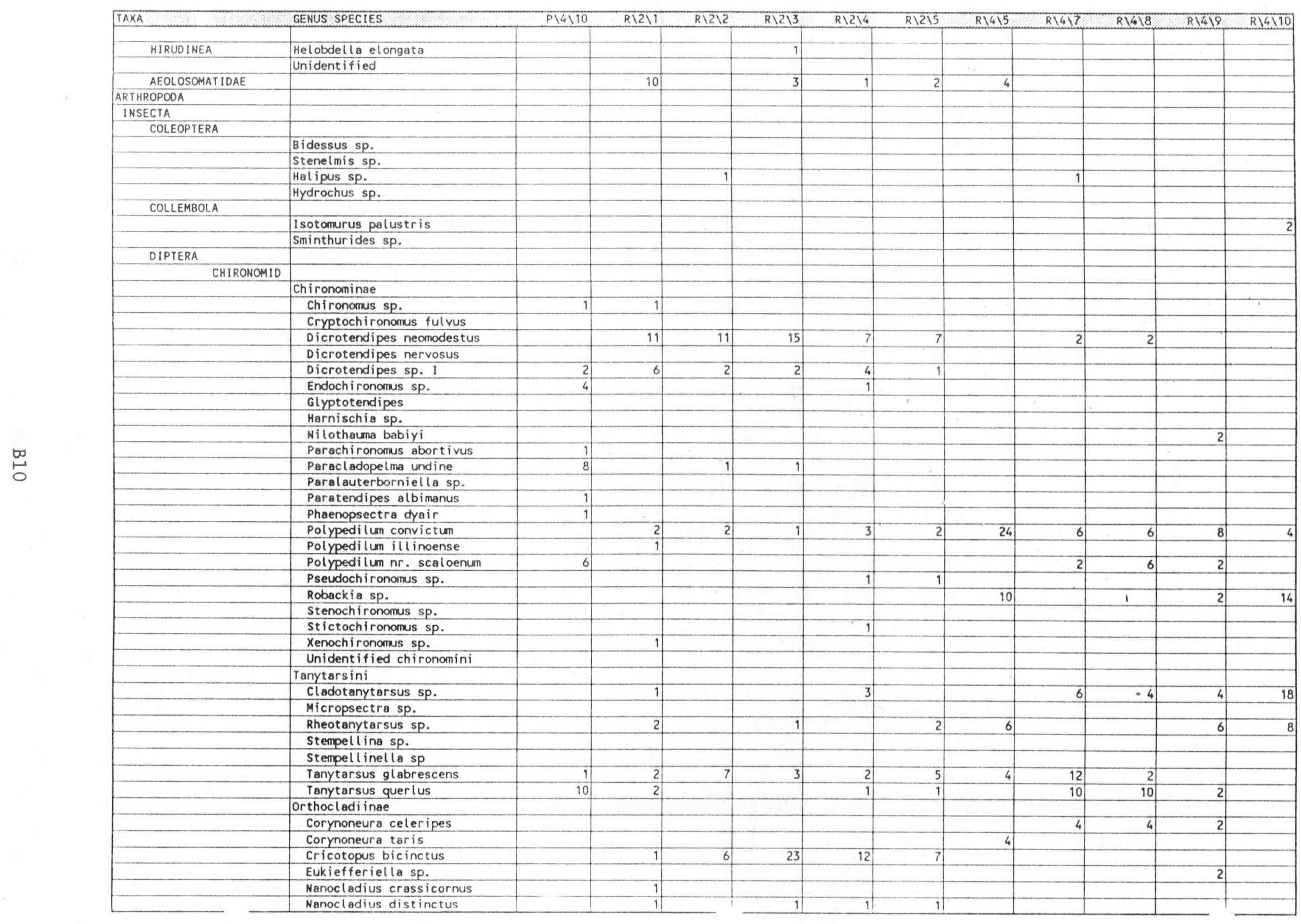




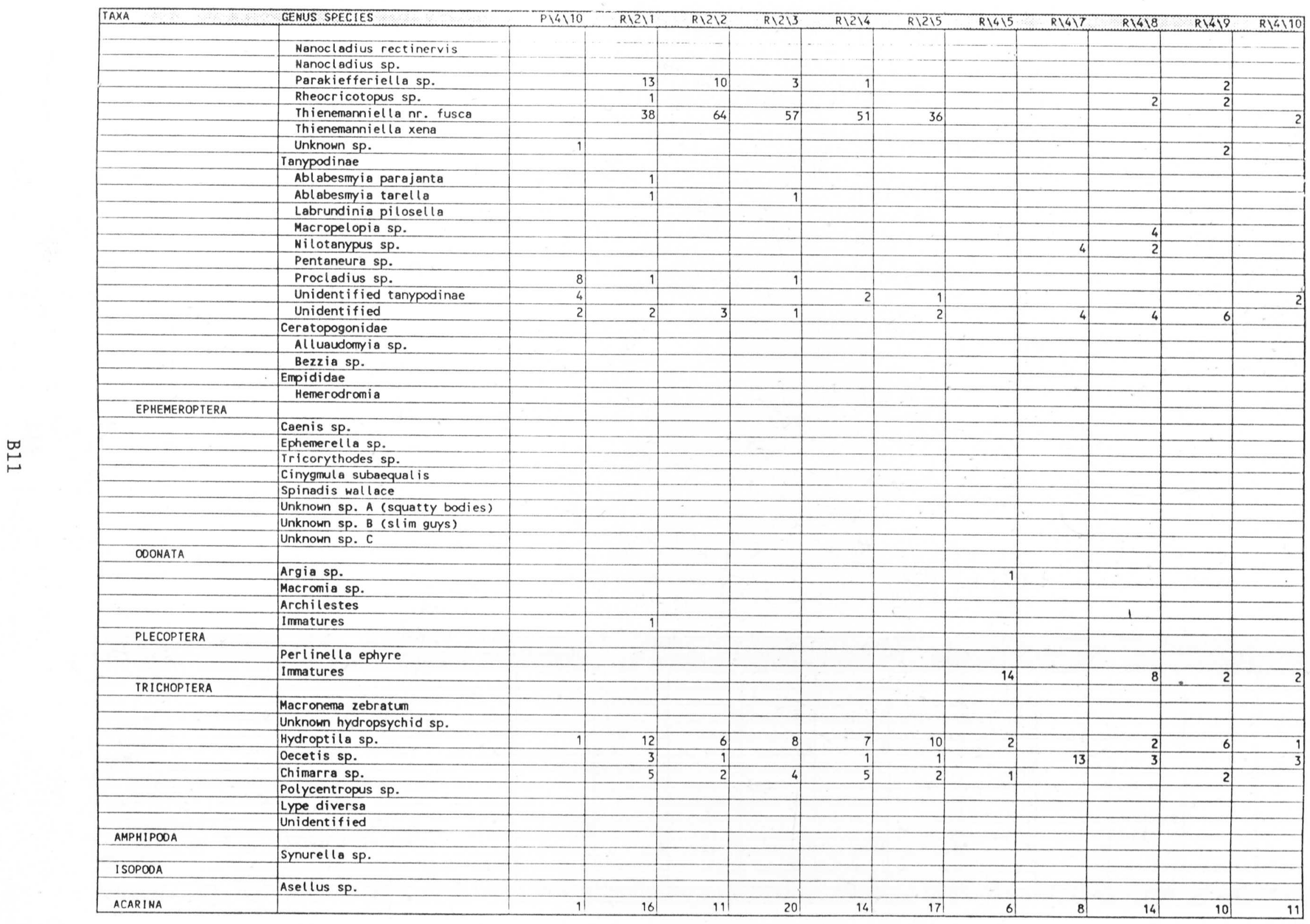




\begin{tabular}{|c|c|c|c|c|c|c|c|c|c|c|c|c|}
\hline$I A \times A$ & GENUS SPECIES & $P \backslash 4110$ & Rाटा1 & $R \backslash 2 \backslash 2$ & $R \backslash 2 \backslash 3$ & $R \backslash 216$ & $R \backslash 2 \backslash 5$ & RI4 5 & $R(6) ?$ & R1618 & Rतk 9 & $R \longdiv { 4 } 1 1 0$ \\
\hline & & & & & & & & & & & & \\
\hline \multicolumn{12}{|l|}{ MOLLUSCA } & \\
\hline PELECYPODA & Corbicula fluminea & & 2 & 4 & 2 & 11 & 8 & 4 & 4 & 7 & 2 & 5 \\
\hline \multirow[t]{4}{*}{ GASTROPODA } & Ferrissia rivularis & 2. & & & & & & & & & & \\
\hline & Amicola sp. & & & & & & & & & & & \\
\hline & Gyraulus sp. & & & & & & & & & & & \\
\hline & Unidentified & & & & & & & & & & & \\
\hline \multicolumn{13}{|l|}{ OTHER } \\
\hline NEMATODA & & 4 & & & 2 & 1 & & 1 & 1 & 2 & 1 & 1 \\
\hline \multicolumn{13}{|l|}{ NEMERTEA } \\
\hline & Prostoma graecense & & & 1 & & 1 & & & 1 & & & \\
\hline & & & & & & & & & & & & \\
\hline & & Ti: & 258 & 953 & 168 & 175 & 121 & 804 & $8 \%$ & 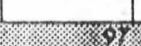 & 876 & \\
\hline 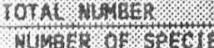 & . & 24 & 36 & 25 & 28 & 32 & 26 & 2 & $2 \pi$ & 23 & 35 & 20 \\
\hline
\end{tabular}


APPENDIX $C$

COUNTS OF MAJOR TAXA PER CORE SAMPLE, FALL, 1988 



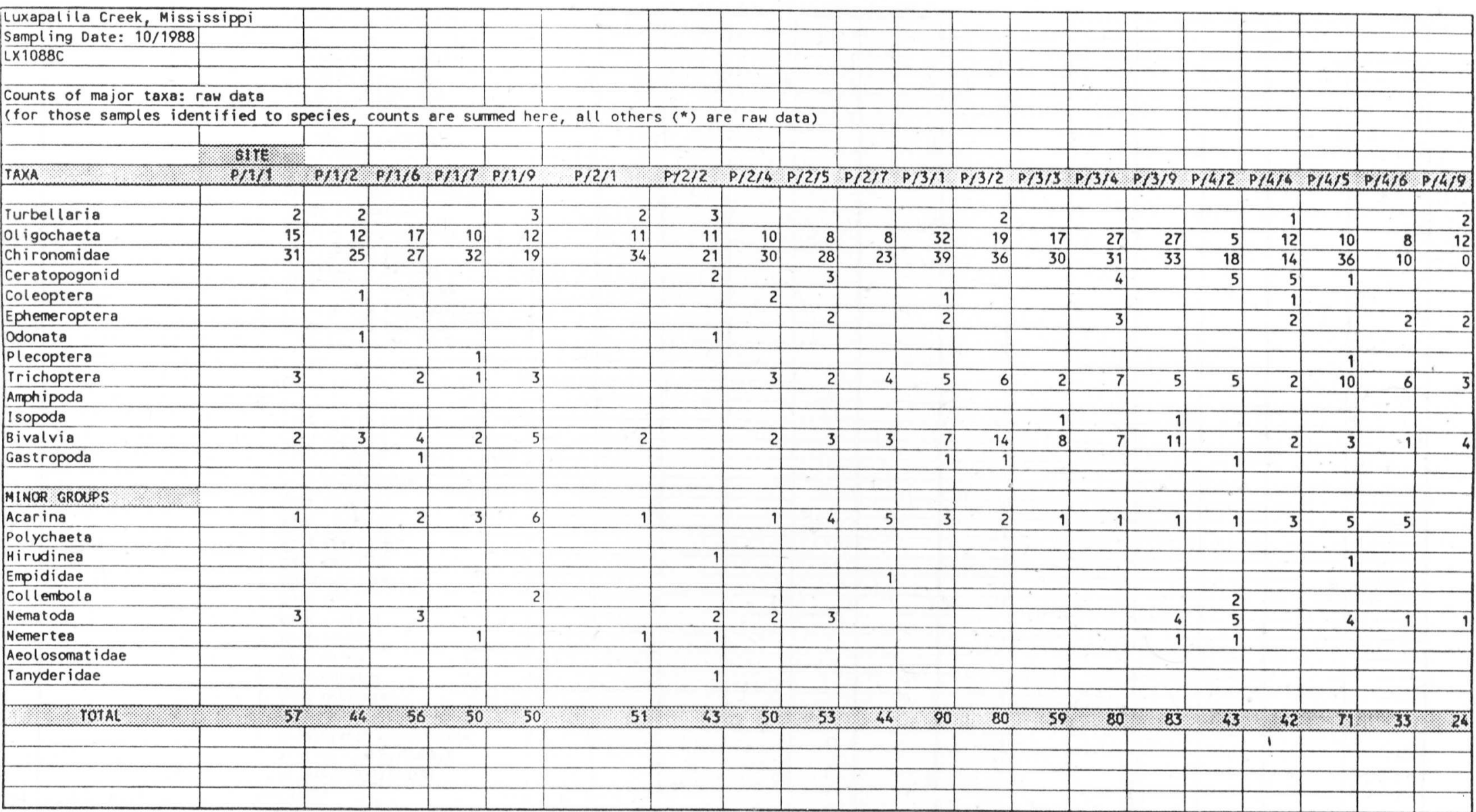




\begin{tabular}{|c|c|c|c|c|c|c|c|c|c|c|c|c|c|c|}
\hline \multicolumn{2}{|c|}{ Luxapalila Creek, Mississippi } & & $\therefore$ & & & & & & 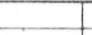 & & & & & \\
\hline \multirow{3}{*}{$\begin{array}{l}\text { Sampl ing Date: } 10 / 88 \\
\text { Lx1088sa }\end{array}$} & & & & & & & & & & & & & & \\
\hline & & & & & & & & & & & & & & TOTAL \\
\hline & & SITE & & & & & FREQ & & & & & & FREQ & FREQ \\
\hline \multirow{2}{*}{\multicolumn{15}{|c|}{$\begin{array}{l}\text { TAXA } \\
\text { PLATYHELMINTHES }\end{array}$}} \\
\hline & & & & & & & & & & & & & & \\
\hline \multicolumn{15}{|l|}{ TURBELLARIA } \\
\hline & Dugesia tigrina & 2. & 3. & & & & 2 & & 1 & & & 2 & 2. & 4 \\
\hline & Planaris sp. & & & & & & 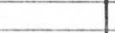 & & - & & & & & \\
\hline & Unidentified & & & & & & & & & & & & & \\
\hline \multicolumn{15}{|l|}{$\begin{array}{l}\text { ANNEL IDA } \\
\text { POLYCHAETA }\end{array}$} \\
\hline \multirow{2}{*}{\multicolumn{15}{|c|}{$\begin{array}{l}\text { POLYCHAETA } \\
\text { OLIGOCHAETA }\end{array}$}} \\
\hline & & & & & & & & & & & & & & \\
\hline & Haplotaxidae & & & & & & & & & & & & & \\
\hline & Lumbricul idae & & 1 & & & & 1 & & 2 & 3 & & & 2 & 3 \\
\hline & Naididae & & & & & & & & & & & & & \\
\hline & Amphichaeta leydigi & & & 1 & 1 & & 2 & & & & & & & 2 \\
\hline & Bratislavia bilongata & & & & & & & & & & & & & \\
\hline & Bratislavia unindentata & & & & & & & & & & & & & \\
\hline & Chaetogaster diaphanus & & & & & & & & & & & & & \\
\hline & Dero digitata & & & & & & & & & & & & & \\
\hline & Dero furcata & & & & & & & & & & & & & \\
\hline & Dero nivea & & & & & & & & & & & & & \\
\hline & Dero obtusa & & & & & & & & & & & & & \\
\hline & Dero trifida & & & & & & & & 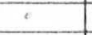 & & & & & \\
\hline & Dero sp. & & 2 & & 2. & 1 & 3 & & & . & & & & 3 \\
\hline & Homochaeta naidina & & & & & & & & & & & & & \\
\hline & Kais behningi & & & & & & & & & & & & & \\
\hline & Nais bretscheri & & & & & & & & & & & & & \\
\hline & Nais communis & & & & & & & & & & & & & \\
\hline & Nais pardalis & & & & & & & & & & & & & \\
\hline & Nais pseudobtusa & & & & & & & & & & & & & \\
\hline & Nais simplex & & & & & & & & & & & & & \\
\hline & Nais variablis & & & & & & & & & & & & & \\
\hline & Piqueriella michiganes is & & & & & & & & & & & 3 & 1 & 1 \\
\hline & Pristina aquiseta & & & & & & & & & & & 1 & & \\
\hline & Pristina leidyi & & & & & & & & & & & 1 & & \\
\hline & Pristina synclites & & & & & & & & & & & & & \\
\hline & Pristina sp. & & & & & & & & & & & & & \\
\hline & Pristinella jenkinae & & & & & & & & & & & & & \\
\hline & Pristinella longidentata & & & & & & & & & & & & & \\
\hline & Pristinella longisoma & & & & & & & & & & . & & & \\
\hline & Pristinella osborni & & & & & & & & & & & & & \\
\hline & Pristinella sima & & & & & & & & & & & & & \\
\hline & Slavina appendiculata & & & & & & & & & & & & & \\
\hline & Specaria josinae & & & 1 & & & 1 & & & & & & & 1 \\
\hline & Stevensoniana trivandrama & & & & & & & & & & & & & \\
\hline & Unidentified naididae & & & & & & & & & & & & & \\
\hline & Tubificidae & & & & & & & & & & & & & \\
\hline & Aulodrilus limnobius & & 1 & & & & 1 & & & 1 & & & 1 & 2 \\
\hline & Aulodrilus piquet $i$ & 4 & & & 2 & 4 & 3. & 3 & & 2 & 3 & 4 & 4) & 7 \\
\hline & Aulodrilus pluriseta & & & & & & & 1 & 1 & & 1 & 1 & 4 & 4 \\
\hline & Branchiura sowerbyi & 3 & & 4 & 2 & 2 & 4 & t & 7 & & & & 7 & 4 \\
\hline & Limnodrilus hoffmeisteri & 1 & 1 & & & 1 & 3 & 1. & 1 & 1 & & & 3 & 6 \\
\hline & Limnodrilus rubripenis & & & & & & & & & & & & & \\
\hline & Potamothr is vejdovskyi & & & & & & & & & & & & & \\
\hline
\end{tabular}




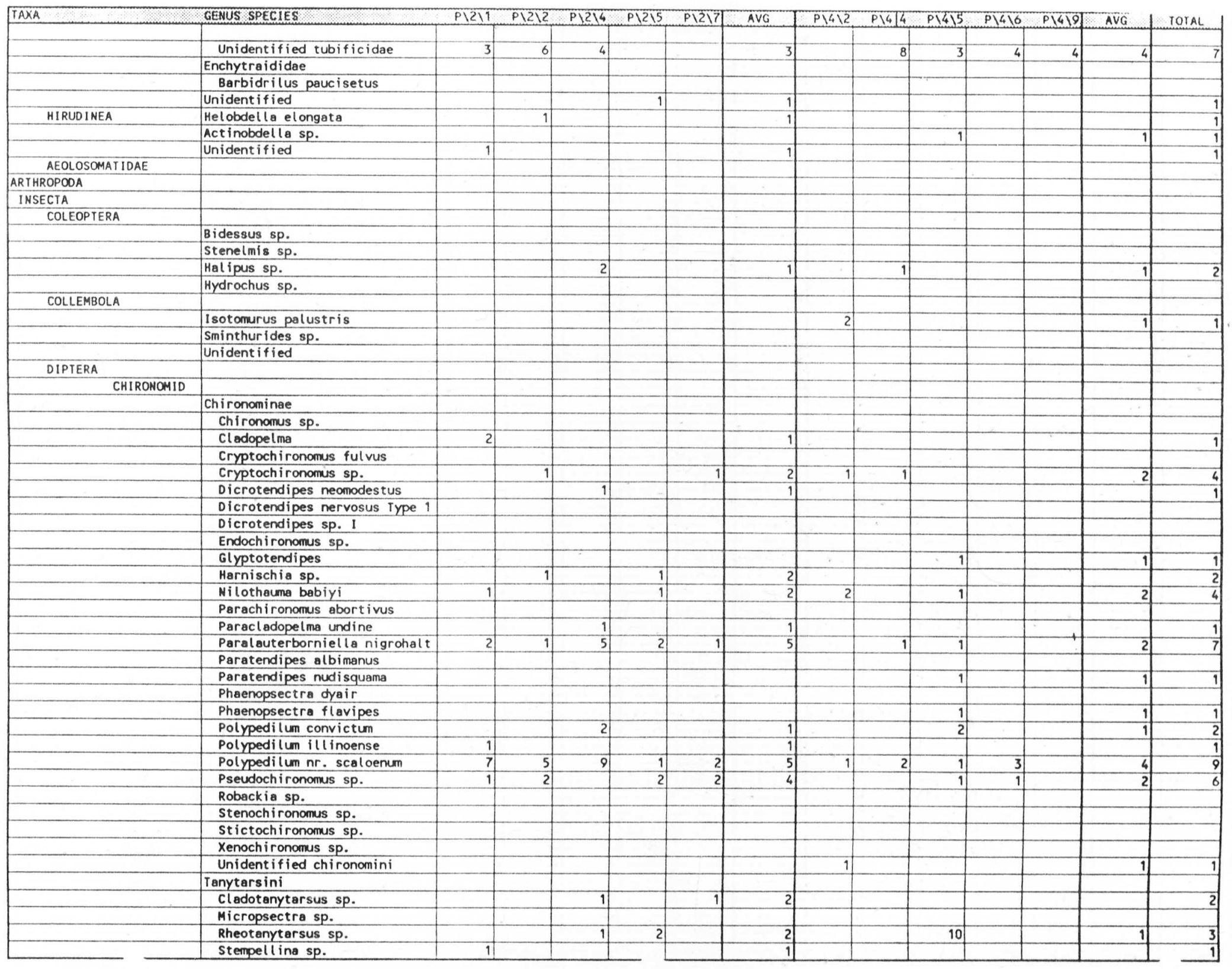




\begin{tabular}{|c|c|c|c|c|c|c|c|c|c|c|c|c|c|c|}
\hline TAXA & GENUS SPECIES & P\211 & $P 12 \backslash 2$ & P1214 & $P \backslash 215$ & P1217 & $A V G$ & P\412 & P14/4 & P14 & P) 46 & 8649 & $\mathrm{AVG}$ & TOTAL \\
\hline & & & & & & & & & & & & & & \\
\hline & Stempellinella sp & & & & & & & & & & & & & \\
\hline & Tanytarsus coffmani & & & & & & & & & & & & & \\
\hline & Tanytarsus glabrescens & & 2 & & 6 & 5 & 3 & & & & & & & 3 \\
\hline & Tanytarsus querlus & 6 & & & 2 & & 2 & & & 2 & & & 1 & 3 \\
\hline & Unidentified tanytarsini & & & & & & & & & & & & & \\
\hline & Orthocladiinae & & & & & & & & & & & & & \\
\hline & Corynoneura celeripes & & & & & & & & & & & & & \\
\hline & Corynoneura taris & & & & & & & & & & & & & \\
\hline & Corynoneura sp & & & & & & & & & & & & & \\
\hline & Cricotopus bicinctus & 2 & & 2 & 3 & & 3 & 1 & & & & & 1 & \\
\hline & Cricotopus sp & & 1 & & & & 1 & 1 & & 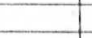 & & & 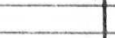 & \\
\hline & Eukiefferiella sp. & 3 & & & & & 1 & & & & & & & \\
\hline & Nanocladius crassicornus & & & 1 & & & 1 & & & 3 & & & 1 & 2 \\
\hline & Nanocladius distinctus & & & & & & & & & & & & 1 & \\
\hline & Manocladius rectinervis & & & & & & & & & & & & & \\
\hline & Nanocladius minimus & & 1 & & & & 1 & & & & & & & 1 \\
\hline & Nanocladius sp. & & & & 3 & 2 & 2 & 2 & 1 & & & & 2 & 4 \\
\hline & Parakiefferiella sp. & & & & 1 & & 1 & & & & & & & 1 \\
\hline & Rheocricotopus sp. & & & & & & T & & & & & & & \\
\hline & Thienemannimyia & & & & & & 1 & & & & 1 & & 1 & 1 \\
\hline & Thienemanniella $\mathrm{nr}$. fusca & & & 1 & & & 1 & & & & & & t & 1 \\
\hline & Thienemanniella xena & & & & & & t & & & 1 & & & 1 & 1 \\
\hline & Unidentified orthocladinae & & & & & & t & & . & 2 & & & 1 & 1 \\
\hline & Tanypodinae & & & & & & & $\because$ & & & & & & \\
\hline & Ablabesmyia mallochi & & & 1 & & & 1 & & & & & & & 1 \\
\hline & Ablabesmyia parajanta & & 5 & 3 & 1 & 7 & 4 & 4 & & 7 & 1 & & 3 & 7 \\
\hline & Ablabesmyia tarella & & & & & & ] & & & & & & & \\
\hline & $\mathrm{Clinotanypus}$ & & & & & & & & & 1 & & & 1 & 1 \\
\hline & Labrundinia pilosella & & & & & 1 & 1) & & & & & & & 1 \\
\hline & Macropelopia sp. & & & & & & & & & & & & & \\
\hline & Natarsia sp & & & & & & & & & & & & & \\
\hline & Nilotanypus sp. & & & & & & & & & & & & & \\
\hline & Pentaneura sp. & & & & & & & & & & & & & \\
\hline & Procladius sp. & 4 & 5 & 2 & 2 & 1 & 5 & 3 & 9 & 1 & 3 & & 4 & 9 \\
\hline & Unidentified tanypodinae & 2 & & & 1 & & 1 & 2 & & & & & 1 & 2 \\
\hline & Diames inae & & & & & & & & & & & & & \\
\hline & Potthasia & 1 & & & & & 1 & & & & & & & 1 \\
\hline & Unidentified Chironomidae & 1 & & & 1 & & 2 & 1 & & & 1 & & 2 & 4 \\
\hline & Ceratopogonidae & & & & & & & & & & & & & \\
\hline & Alluaudomyia sp. & & & & & & & 1 & & 1 & & & 2 & 2 \\
\hline & Bezzia sp. & & 2 & & 3 & & 2 & 4] & 5 & & & & 2 & 4 \\
\hline & Unidentified ceratopogonid & & & & & & & & & & & & & \\
\hline & Empididae & & & & & & & & & & & & & \\
\hline & Hemerodromia & & & & & 1 & 1 & & & & & & & 1 \\
\hline & Tanyderidae & & 1 & & & & 1 & & & & & & & 1 \\
\hline & Simuliidae & & & & & & & & & & & & & \\
\hline & simul ium sp. & & & & & & & & & & & & & \\
\hline \multicolumn{15}{|l|}{ EPHEMEROPTERA } \\
\hline & Baetisca sp & & & & & & & & 1 & & & & 1 & 1 \\
\hline & Caenis sp. & & & & & & & & & & & & & \\
\hline & Ephemerella sp. & & & & & & & & & & & & & \\
\hline & Tricorythodes sp. & & & & & & & & & & & & & \\
\hline & Cinygmula subaequal is & & & & & & & & & & & & & \\
\hline & Stenonema sp. & & & & & & & & & & & & & \\
\hline
\end{tabular}




\begin{tabular}{|c|c|c|c|c|c|c|c|c|c|c|c|c|c|c|}
\hline TAXA & GENUS SPECIES & P\217 & 01212 & P) 214 & P1215 & P1217] & $A V G$ & $P \backslash 4 \backslash 2$ & P) $4 \longdiv { 4 }$ & P 1415 & P) 416 & P) 659 & AVG & TOTAL \\
\hline & Soingdis wallace & & & & & & & & & & 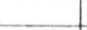 & 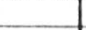 & & \\
\hline & Spinadis wall ace & & & & 2 & & 1 & & & & 2. & 2 & 2 & 3 \\
\hline & Unknown sp. A (squatty bodies) & & & & & & & & & & & & & \\
\hline & Unknown sp. B (slim guys) & & & & & & & & & & & & & \\
\hline & Unknown sp. C & & & & & & & & & & & & & \\
\hline \multirow{7}{*}{ OOONATA } & Unidentified & & & & & & & & 1 & & & & 1 & 1 \\
\hline & & & & & & & & & & & & & & \\
\hline & Argia sp. & & & & & & & & & & & & & \\
\hline & Macromia sp. & & & & & & & & & & & & & \\
\hline & Archilestes & & & & & & & & & & & & & \\
\hline & Dromogomphus sp. & & 1. & & & & 1 & & & & & & & 1 \\
\hline & Immatures & & & & & & & & & & & & & \\
\hline \multicolumn{15}{|l|}{ PLECOPTERA } \\
\hline & Perlinella ephyre & & & & & & & & & & & & & \\
\hline & Immatures & & & & & & & & & & & & & \\
\hline & Unidentified & & & & & & & & & 1 & & & 1 & 1 \\
\hline \multicolumn{15}{|l|}{ TRICHOPTERA } \\
\hline & Ceraclea & & & & & & & 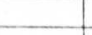 & & & & & & \\
\hline & Macronema zebratum & & & & & & & & & & & & & \\
\hline & Hydroptila sp. & & & & & 1 & 1 & 1. & 2 & 2. & 1 & 1 & 5 & 6 \\
\hline & Oecet is sp. & & & 1. & & & 1 & & & 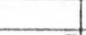 & 2. & 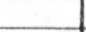 & 1 & 2 \\
\hline & Chimarra sp. & & & 2. & 2 & 3 & 3. & 4 & & 7 & 3 & 2 & 4 & 7 \\
\hline & Polycentropus sp. & & & & & & {$[-$} & & & 1 & & & 1 & 1 \\
\hline & Lype diversa & & & & & & & & & & & & & \\
\hline & Unidentified & & & & & & & & & & & & & \\
\hline \multicolumn{15}{|l|}{ AMPHIPOOA } \\
\hline & Symurella sp. & & & & & & & & & & & & & \\
\hline \multicolumn{15}{|l|}{ ISOPOOA } \\
\hline & Asellus sp. & & & & & & & & & & & & & \\
\hline ACARINA & & 1 & & 1 & 4. & 5 & 4 & 1 & 3. & 5 & 5 & & 4 & 8 \\
\hline \multicolumn{15}{|l|}{ MOLLUSCA } \\
\hline PELECYPOOA & Corbicula flumines & 2 & & 2. & 3. & 3 & 4 & & 2. & 3 & 1 & 4 & 4 & 8 \\
\hline \multirow[t]{4}{*}{ GASTROPOOA } & Ferrissia rivularis & & & & & & & 1 & & & 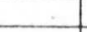 & & 1 & 1 \\
\hline & Amnicola sp. & & & & & & & & & & & & & \\
\hline & Gyraulus sp. & & & & & & & & & & & & & \\
\hline & Unidentified & & & & & & & & & & & & & \\
\hline \multicolumn{15}{|l|}{ OTHER } \\
\hline NEMATODA & & & 2 & 2. & 3. & & 3 & 5. & & & 1 & 1 & 3 & 6 \\
\hline \multirow[t]{2}{*}{ NEMERTEA } & & 1 & 1 & & & & 2 & 1 & & & & & 1 & 3 \\
\hline & & & & & & & & & & & & & & \\
\hline
\end{tabular}




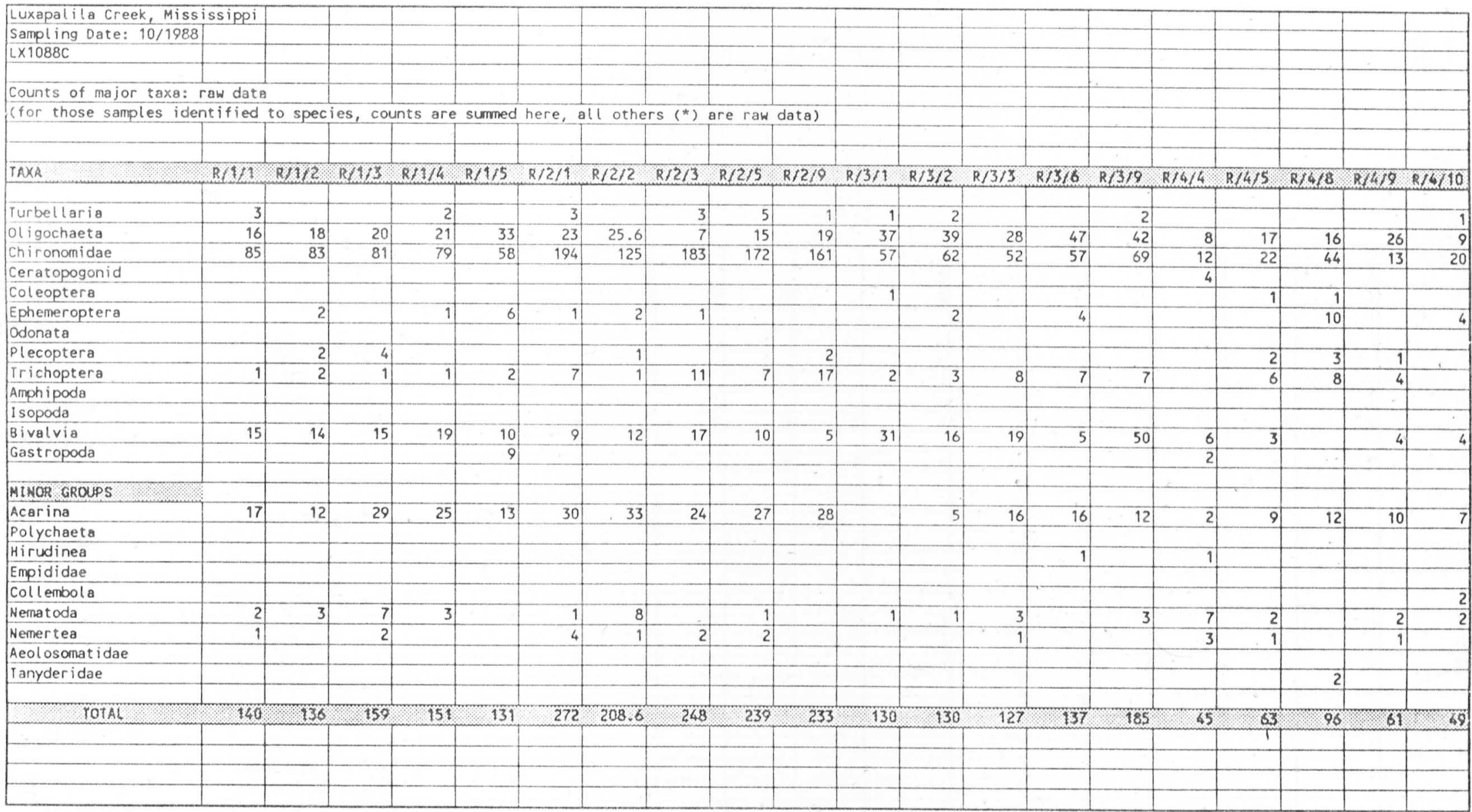




\begin{tabular}{|c|c|c|c|c|c|c|c|c|c|c|c|c|c|c|}
\hline Luxapalila Creek, Mi & ippi & & & & & & & & & & & & & \\
\hline Sampling Date: $10 / 88$ & & & & & & & & & & & & & & \\
\hline LX1088SQ & & & & & & & & & & & & & & TOYAL \\
\hline & & & & & & & FREQ & & & & & & FREQ & FREQ \\
\hline TAXA & GENUS SPEETES & $\mathrm{R} \backslash 2 \backslash 1$ & $R \backslash 2 \backslash 2$ & $R \backslash 2 \sqrt{3}$ & $R \backslash 2 \backslash 5$ & RI219 & $R / 2$ & $R \backslash 4 \backslash 4$ & R\4\S & $R \backslash 418$ & R\419 & $814 \times 190$ & $\mathrm{R} / 4.3$ & 10 \\
\hline PLATYHELMINTHES & & & & & & & & & & & & & & \\
\hline TURBELLARIA & & & & & & & & & & & & & & \\
\hline & Dugesia tigrina & 3 & & 3 & 5 & 1 & 4 & & & & & 1) & 1 & 5 \\
\hline & Planaria sp. & & & & & & & & & & & & & \\
\hline & Unidentified & & & & & & & & & & & & & \\
\hline ANNELIDA & & & & & & & & & & & & & & \\
\hline POLFEHAETA & & & & & & & & & & & & & 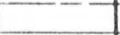 & \\
\hline OLIGOCHAETA & Sparganophilus & & & & & & & & & & & & & \\
\hline & Haplotaxidae & & & & & & & & & & & & & \\
\hline & Lumbricul idae & 4. & 3 & & & 2 & 3 & 6 & 6 & 1 & 20 & 4 & 5 & 8 \\
\hline & Naididae & & & & & & & & & & & & 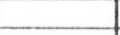 & \\
\hline & Amphichaeta leydigi & & & & & & & & & & & & & \\
\hline & Bratislavia bilongata & & & & & & & & & & & & & \\
\hline & Bratislavia unindentata & & & & & & & & & & & & & \\
\hline & Chaetogaster diaphanus & & & & & & & & & & & 1 & 1 & 1 \\
\hline & Dero digitata & & & & & & & & & & & & & \\
\hline & Dero furcata & & & & & & & & & & & & & \\
\hline & Dero nives & 5 & 2 & 1 & 3 & 3 & 5 & & & & & & & 5 \\
\hline & Dero obtusa & & 2 & 1 & 8 & 3 & 4 & & 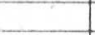 & & & & & 4 \\
\hline & Dero trifida & & 2. & & & & 1 & &. & & & & & 1 \\
\hline & Dero sp. & & & & & & & & & & 3. & & 1 & 1 \\
\hline & Homochaeta naidina & & & & & & & & & & & & 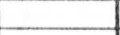 & \\
\hline & Nais behningi & & & & & & & & & & & & & \\
\hline & Nais bretscheri & & & & & & & & & & & & & \\
\hline & Nais communis & & & & & & & & & & & & & \\
\hline & Nais pardal is & 3 & 4. & 1 & 1 & 2 & 5 & 1 & & 1 & & & 2 & 7 \\
\hline & Nais pseudobtusa & 1 & & & & & 1 & & & 1 & & & 1 & 2 \\
\hline & Nais simplex & 2 & & & & & 1 & & 1 & & & & 1 & 2 \\
\hline & Nais veriablis & 5 & 1 & & & 8 & 3 & & & & & & & 3 \\
\hline & Piquetiella michiganesis & & & & & & & & & 9 & & & 1 & 1 \\
\hline & Pristina aquiseta & & & & & & & & 1 & 1 & & & 2 & 2 \\
\hline & Pristina leidyi & & & & & & & & & & & 1 & & \\
\hline & Pristina synclites & & & & & & & & & & & & & \\
\hline & Pristina sp. & & & & & & & & & & & 1 & 1 & 1 \\
\hline & Pristinella jenkinae & & & & & & & & & & & & & \\
\hline & Pristinella longidentata & & & & & & & & & & & & & \\
\hline & Pristinella longisoma & & & & & & & & & & & & & \\
\hline & Pristinella osborni & 1 & 1. & & & & 2 & & & & 1 & & 1 & 3 \\
\hline & Pristinella sima & & & & & & & & & & & & & \\
\hline & Slavina appendiculata & & 1 & & & & 1 & & & & & & & 1 \\
\hline & Specaria josinae & & & & & & & & & & 1 & & 1 & 1 \\
\hline & Stevensoniana trivandrama & & & & & & & & & & & & & \\
\hline & Unidentified naididae & 1 & & & & & 1 & & & & & & & 1 \\
\hline & Tubificidae & & & & & & & & & & & & & \\
\hline & Aulodrilus limnobius & & & & & & & & & & & & & \\
\hline & Aulodrilus piquet $i$ & & & & & & & & & & 1 & & 1 & 1 \\
\hline & Aulodrilus pluriseta & & & & & & & & & & & & & \\
\hline & Branchiura sowerbyi & & 1 & 1 & & & 2 & & & & & & & 2 \\
\hline & Limnodrilus hoffmeisteri & & & & & & t & & & & & & & \\
\hline & Limnodrilus rubripenis & 1 & & & & & 1 & & & & & & & 1 \\
\hline & Potamothris vejdovskyi & & & & & & & & & & & & & \\
\hline
\end{tabular}




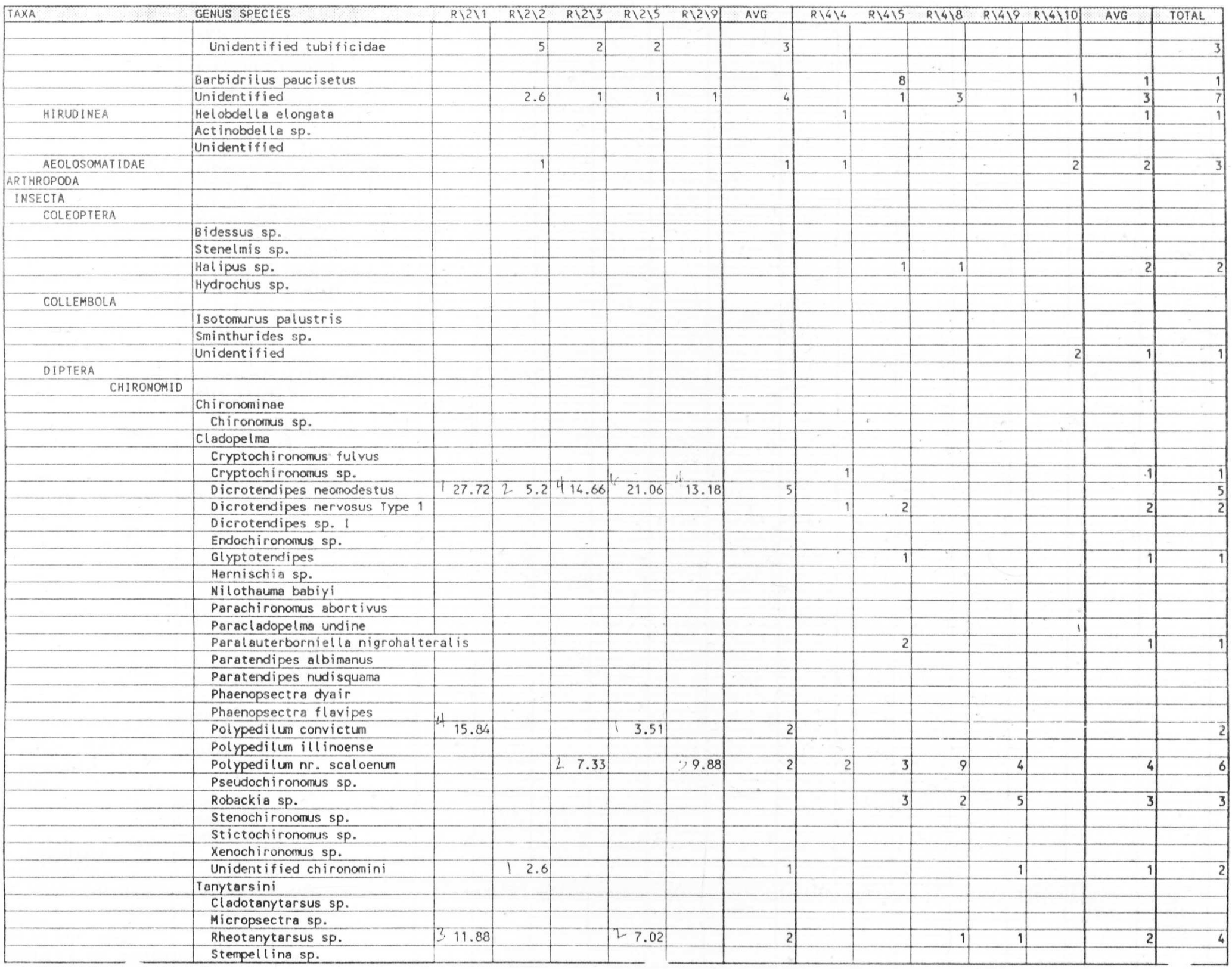




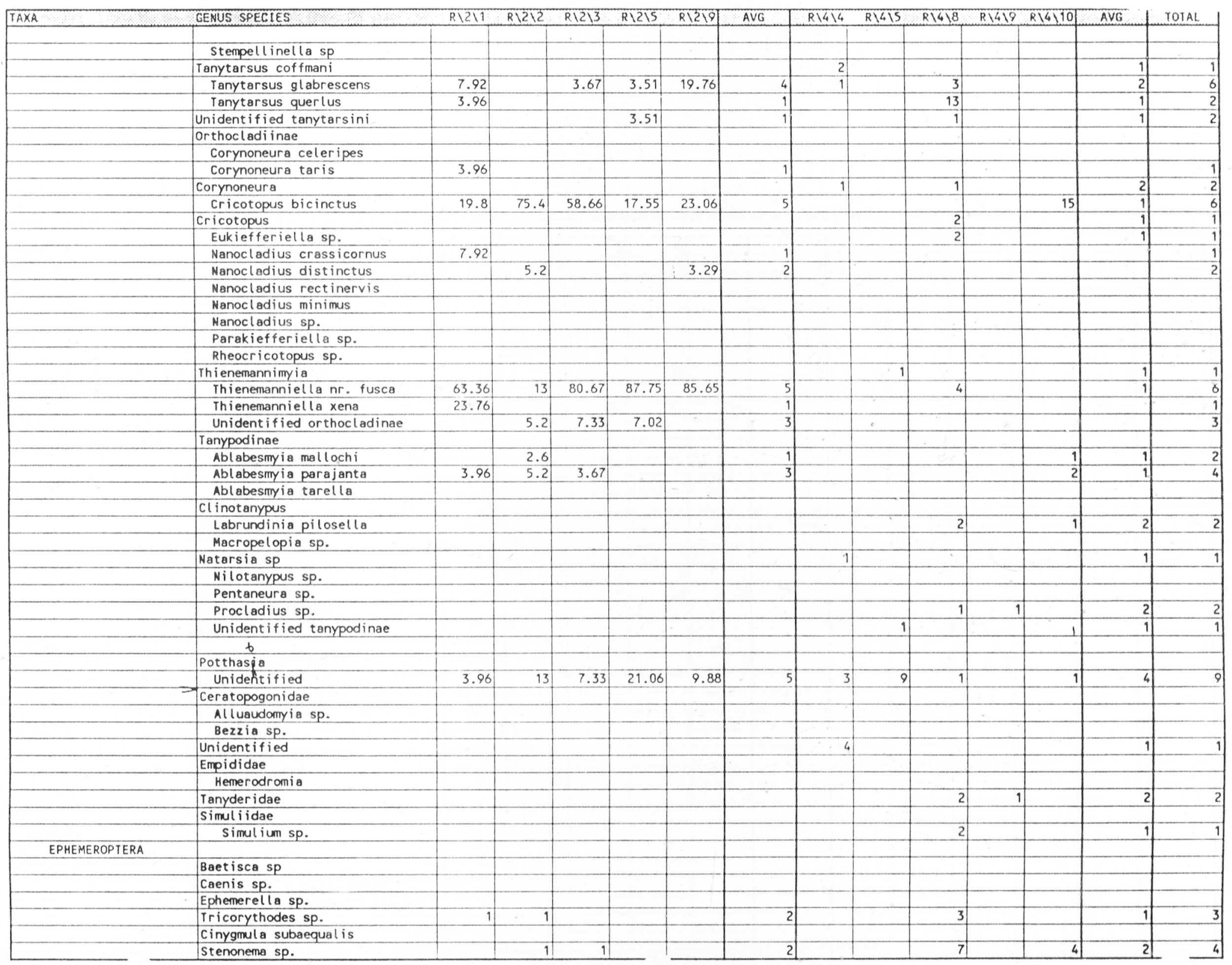




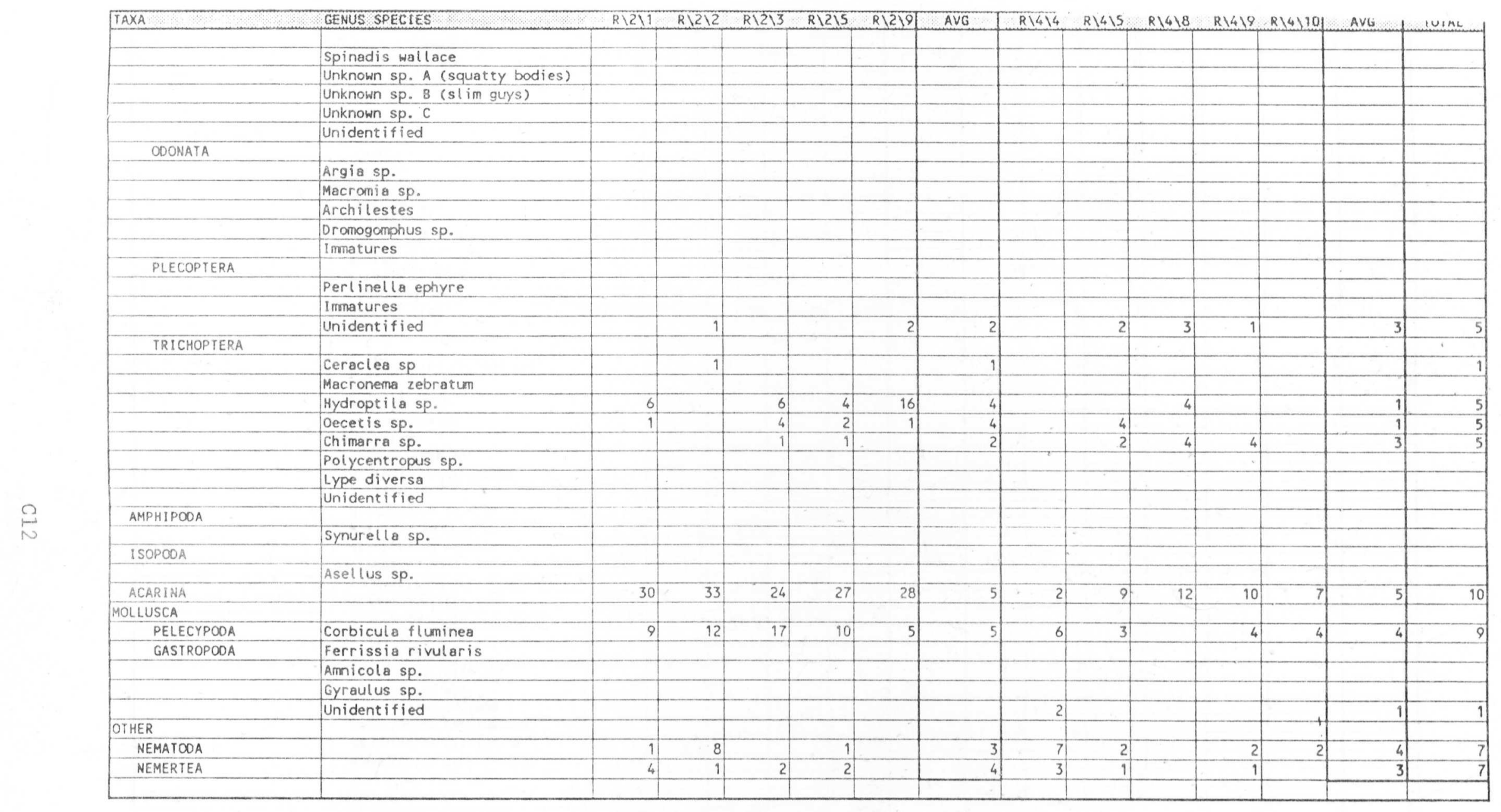


APPENDIX D

SPECIES COMPOSITION IN SPRING, 1989 SAMPLES 
Luxapalila Creek, Mississippi

Sampling Date: $6 / 1989$

Counts of major taxa: raw data

(for those samples identified to species, counts are summed here, all others are raw data)

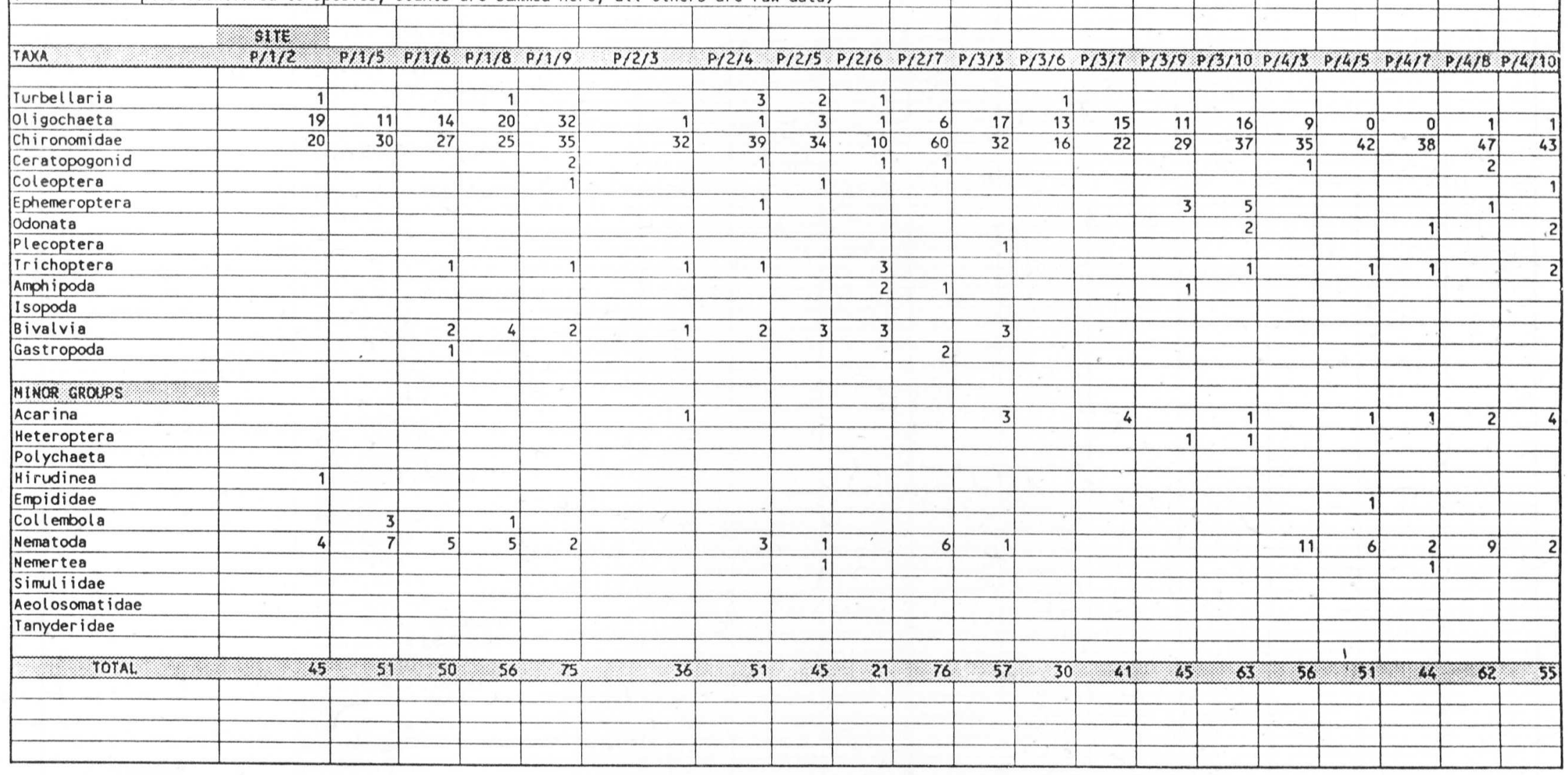




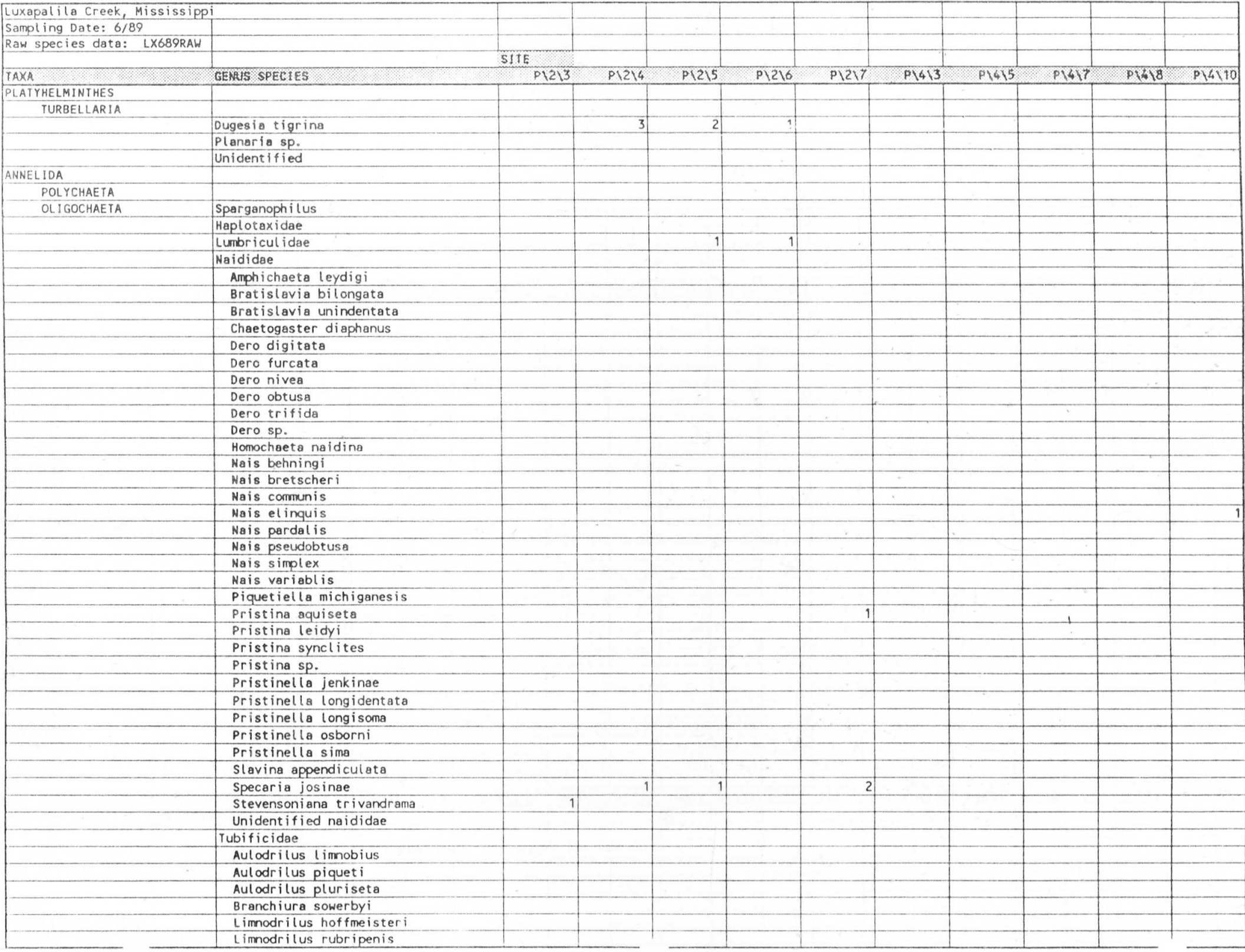




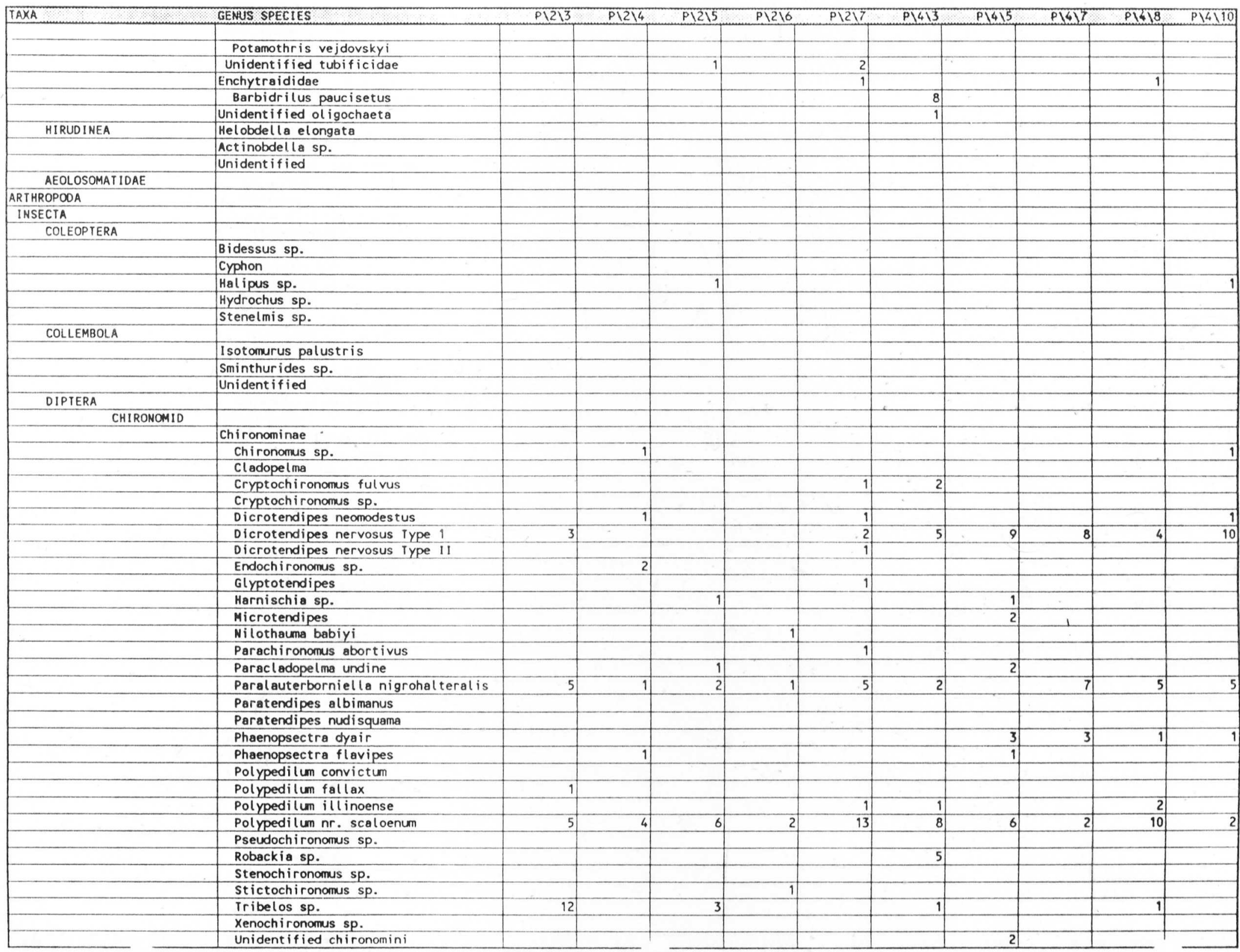




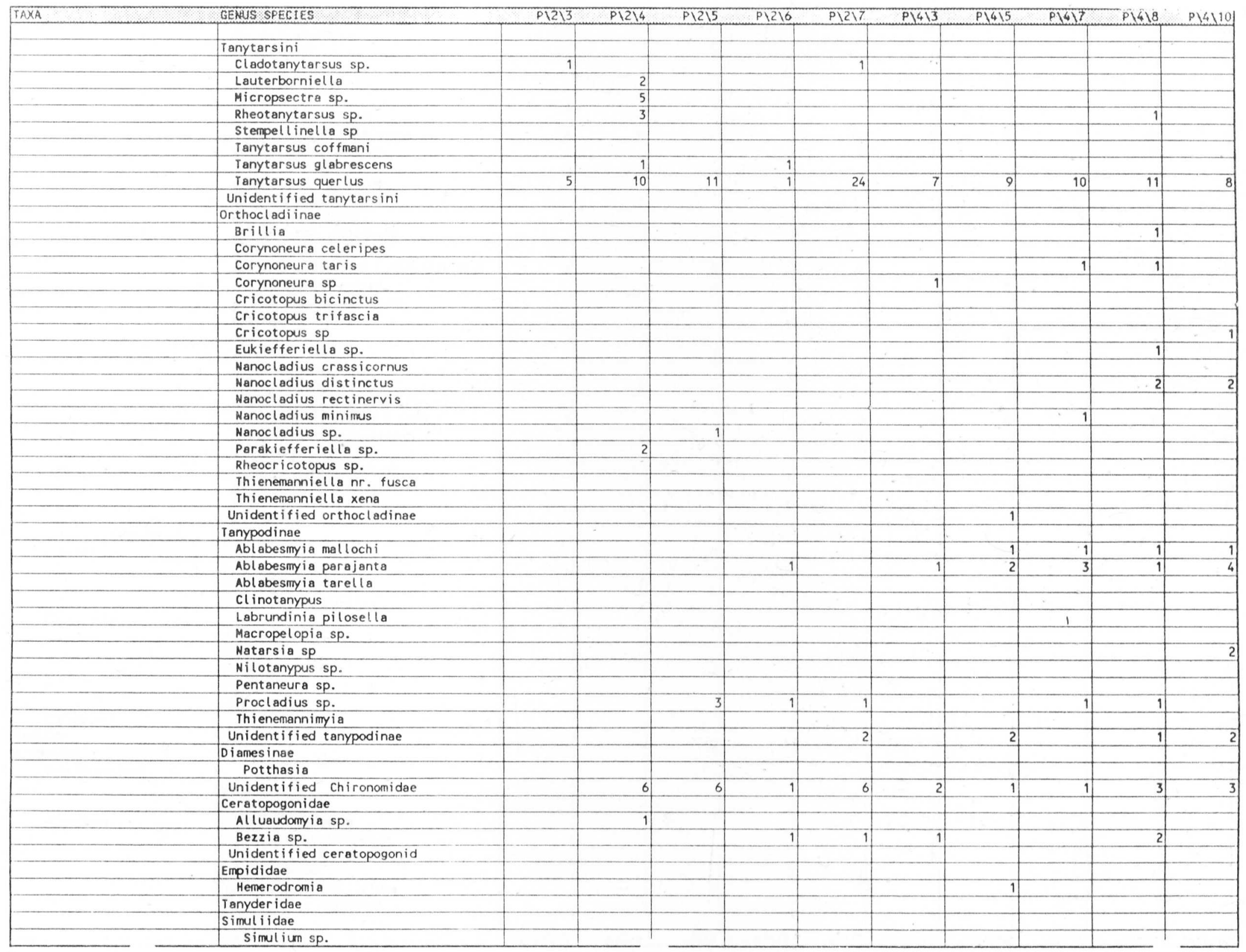




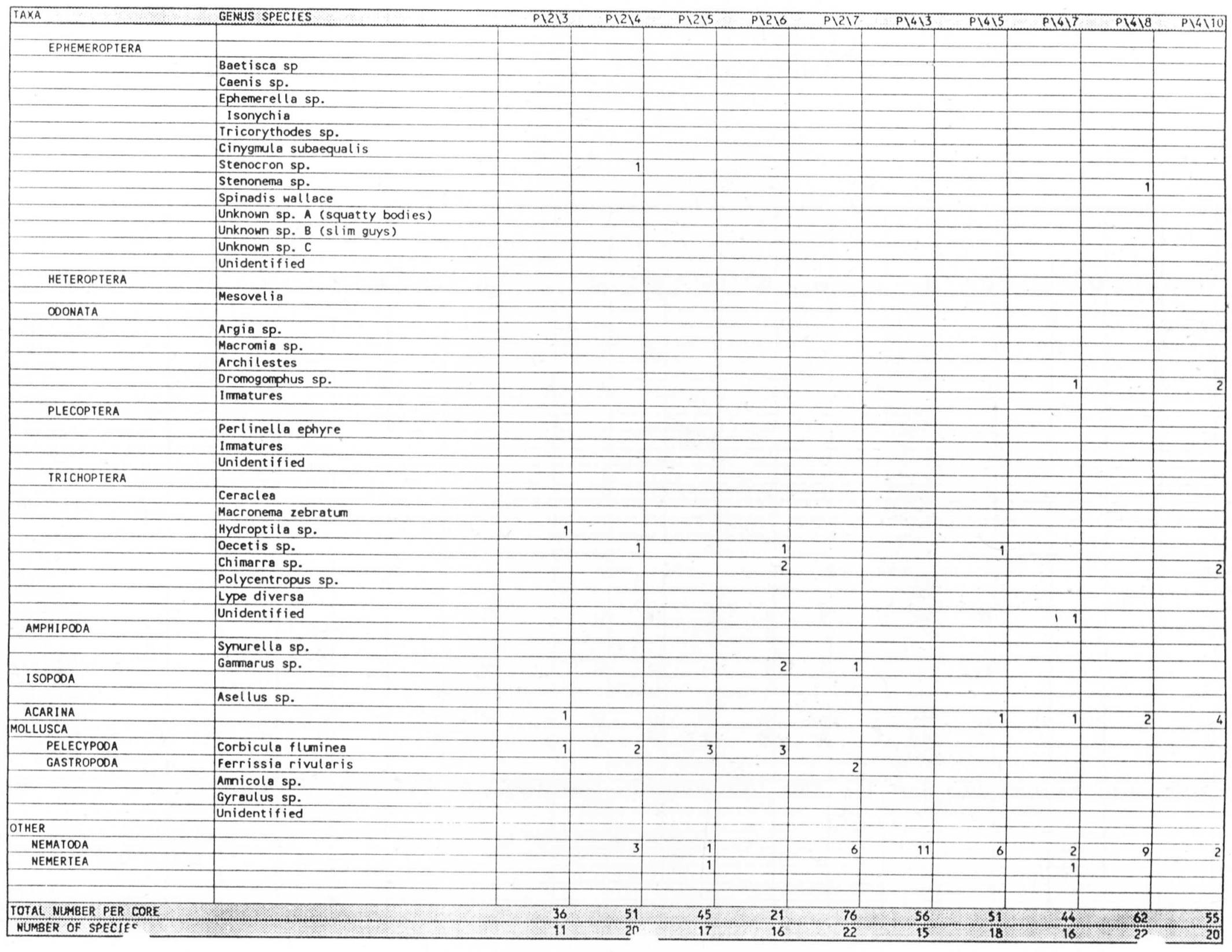




\begin{tabular}{|c|c|c|c|c|c|c|c|c|c|c|c|c|c|c|c|c|c|c|c|c|}
\hline \multicolumn{21}{|c|}{ Luxapalila Creek, Mississippi } \\
\hline \multicolumn{21}{|c|}{ Sampl ing Date: $6 / 1989$} \\
\hline \multirow{2}{*}{\multicolumn{21}{|c|}{ LX889cnt }} \\
\hline & & & & & & & & & & & & & & & & & & & & \\
\hline \multirow{2}{*}{\multicolumn{21}{|c|}{$\begin{array}{l}\text { Counts of major taxa: raw data } \\
\text { for those samoles identified to species, counts are summed here all others are raw data) }\end{array}$}} \\
\hline \multirow{2}{*}{\multicolumn{21}{|c|}{ ifor those samples identified to species, counts are sumed here, all others are raw data) }} \\
\hline & & & & & & & & & & & & & & & & & & & & \\
\hline & Site & & & & & & & & & & & & & & & & & & & \multirow[b]{2}{*}{$8 / 4 / 10$} \\
\hline \multirow[t]{2}{*}{ IAXA } & $\mathrm{R} / \mathrm{t} / 1$ & $\mathrm{R} / 1 / 2$ & $R / 9 / 4$ & $8 / 1 / 5$ & $R / 1 / 10$ & $R / 2 / 9$ & $R / 2 / 5$ & $R / 2 / 6$ & $R / 2 / 7$ & $R / 2 / 8$ & $R / 3 / 1$ & $R / 3 / 2$ & $R / 3 / 4$ & $R / 3 / 5$ & $\mathrm{R} / 3 / 7$ & $R / 4 / 1$ & $R / 4 / 2$ & $R / 4 / 8$ & $8 / 4 / 9$ & \\
\hline & & & & & & & & & & & & & & 3 & & & & & & \\
\hline Turbellaria & & 4 & & & & & & & & & & & 1 & & & & & & & 2 \\
\hline Ol igochaeta & 10 & 36 & 11 & 18 & 3 & 21 & 5 & 13 & 21 & 14 & 44 & 20 & 13 & 34 & 46 & 2 & 0 & 0 & 1 & 1 \\
\hline Chironomidae & 4 & 10 & 6 & 4 & 4. & 56 & 6 & 37 & 75 & 20 & 36. & 38 & 6 & 338 & 39 & 17 & 14 & 8 & 12 & 23 \\
\hline \multicolumn{21}{|l|}{ Ceratopogonid } \\
\hline Coleoptera & & & & & & & & & 1 & & 1 & & & 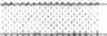 & + & & & & & 1 \\
\hline Ephemeroptera & & & & & 1. & 24 & & 11 & 15 & 1 & 5 & 2 & 2 & $\theta$ & 2 & & & & & \\
\hline \multicolumn{21}{|l|}{ Odonata } \\
\hline Plecoptera & & & & & & & & & & & 2 & & s. & 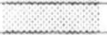 & 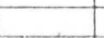 & 3 & 1 & 2 & 1 & 4 \\
\hline Trichoptera & 5 & 2 & & & & 12 & & 21 & 81 & 6 & 6 & 6 & 1 & 22 & 22 & & & & 1 & \\
\hline Amphipoda & & 2 & & & & & & & & & & & & & & & & & 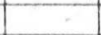 & 1 \\
\hline \multicolumn{21}{|l|}{ Isopoda } \\
\hline Bivalvia & 4 & 11 & & & & & & & & & & & & 1 & & & & & & \\
\hline \multirow[t]{2}{*}{ Gastropoda } & 2 & & & & & & & & & & & & & & & & & & & \\
\hline & & & & & & & & & & & & &. & 18 & & & & & & \\
\hline \multicolumn{21}{|l|}{ MINOR GROUPS } \\
\hline Acarina & 2 & 1 & & $\because$ & & & & 5 & 7 & 1 & 1 & 1 & & 15 & 6 & 3 & 1 & 1 & 1 & 2 \\
\hline \multicolumn{21}{|l|}{ Heteroptera } \\
\hline \multicolumn{21}{|l|}{ Polychaeta } \\
\hline \multirow{2}{*}{\multicolumn{21}{|c|}{$\begin{array}{ll}\text { Hirudinea } \\
\text { Empididae }\end{array}$}} \\
\hline \multicolumn{3}{|l|}{ Empididae } & & & & & & & & & & & & & & & & & & \\
\hline \multicolumn{21}{|l|}{ Collembola } \\
\hline Nematoda & 4 & 4 & 2 & 4 & & & 4. & 2 & & & & & 6 & 13 & 3 & 7 & 4 & 7 & 4 & 1 \\
\hline \multicolumn{21}{|l|}{ Nemertea } \\
\hline Simuli idae & & & & & & & & 4 & 33 & 1 & & 1. & & 1 & & & & & & \\
\hline Aeolosomatidae & & & & & & & & & & & & & & (n) & & & & & & \\
\hline Tanyderidae & & & & & & & & & & & & & & & & & & & & \\
\hline & & & & & & & & & & & & & & & & & 1 & & & \\
\hline TOYAL & 31 & 70 & 19 & 28 & 8 & 113 & 15 & 94 & 233 & 43 & 93 & 68 & 29 & 430 & 118 & 32 & 20 & 18 & 20 & 35 \\
\hline & & & & & & & & & & & & & & & & & & & & \\
\hline & & & & & & & & & & & & & & & & & & & & \\
\hline & & & & & & & & & & & & & & & & & & & & \\
\hline & & & & & & & & & & & & & & & & & & & & \\
\hline
\end{tabular}




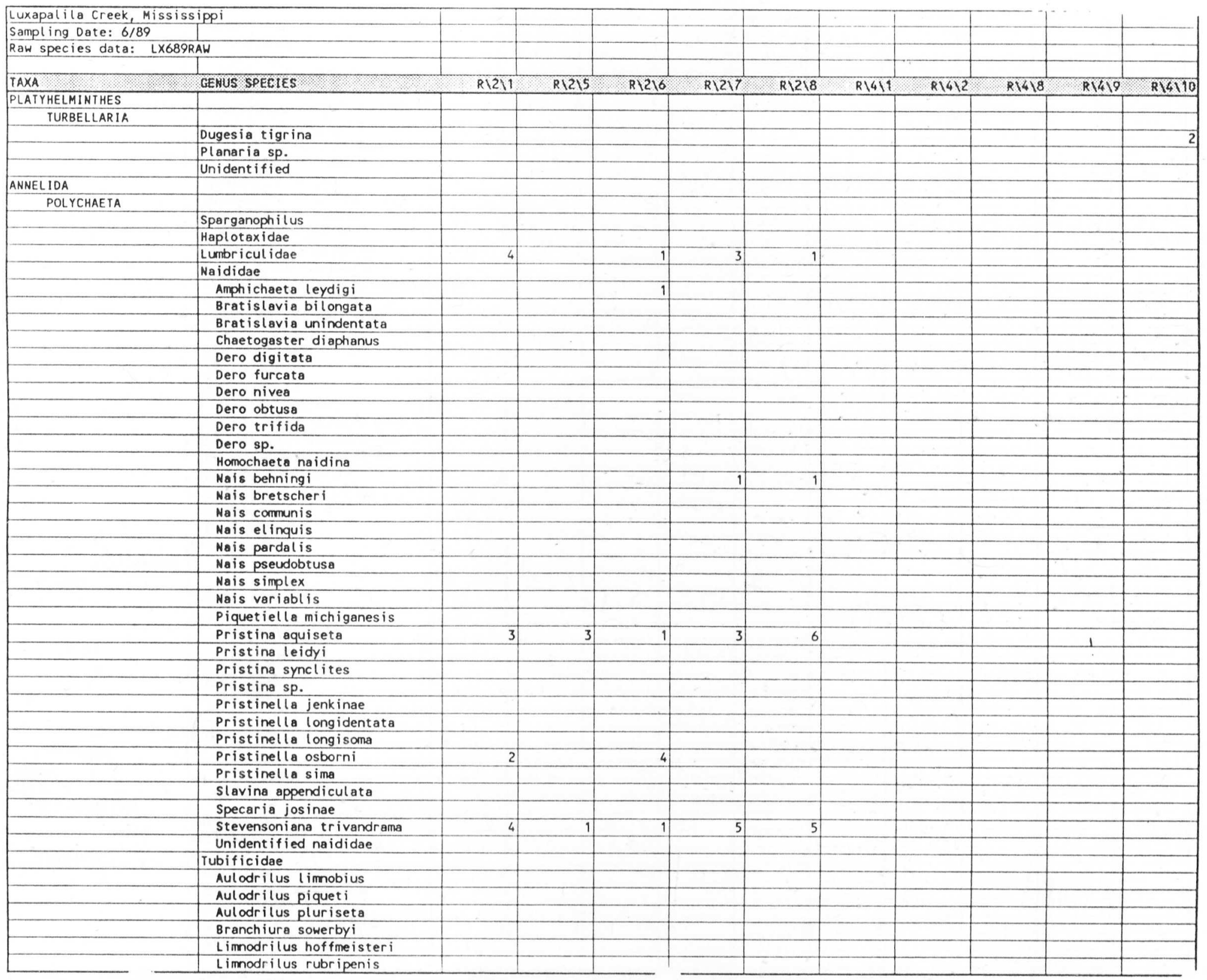




\begin{tabular}{|c|c|c|c|c|c|c|c|c|c|c|c|}
\hline TAXA & GENUS SPECIES & $R \backslash 2 \backslash 1$ & 81215 & $R \backslash 2 \backslash 6$ & $R \backslash 2 \backslash 7$ & Rी218 & $R \backslash 4 \backslash 7$ & $R 1412$ & 81418 & $R \backslash 419$ & $R \backslash 4 \backslash 10$ \\
\hline & Potamothris vejdovskyi & & & & & 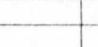 & & & & 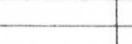 & \\
\hline & Unidentified tubificidae & 1 & 1 & 2 & & 1 & 1 & . & & & \\
\hline & Enchytraididae & & & & & & & & & & \\
\hline & Barbidrilus paucisetus & & & & & & & & & 1. & \\
\hline & Unidentified oligochaeta & 7 & & 3 & 9 & & 1 & & & & \\
\hline HIRUDINEA & Helobdella elongata & & & & & & & & & & \\
\hline & Actinobdella sp. & & & & & & & & & & \\
\hline & Unidentified & & & & & & & & & & \\
\hline AEOLOSOMATIDAE & & & & & & & & & & & \\
\hline ARTHROPODA & & & & & & & & & & & \\
\hline INSECTA & & & & & & & & & & & \\
\hline COLEOPTERA & & & & & & & & & & & \\
\hline & Bidessus sp. & & & & & & & - & & & \\
\hline & Cyphon & & & & 1 & & & & & & \\
\hline & Halipus sp. & & & & & & & & & & \\
\hline & Hydrochus sp. & & & & & & & & & & \\
\hline & Stenelmis sp. & & & & & & & & & & \\
\hline COLLEMBOLA & & & & & & & & & & & \\
\hline & I sotomurus palustris & & & & & & & & & & \\
\hline & Sminthurides sp. & & & & & & & & & & \\
\hline & Unidentified & & & & & & & & & & \\
\hline DIPIERA & & & & & & & & & & & \\
\hline CHIRONOMID & & & & & & & . & & & & \\
\hline & Chironominae & & & & & & & & & & \\
\hline & Chironomus sp. & & & & & & & & & & \\
\hline & Cladopelma & & & & & & & & & & $\cdot$ \\
\hline & Cryptochironomus fulvus & & & & & & & & & & \\
\hline & Cryptochironomus sp. & 1 & & & & & & & & & \\
\hline & Dicrotendipes neomodestus & & & & & & & & & & \\
\hline & Dicrotendipes nervosus Type 1 & & & & & & & & & & \\
\hline & Dicrotendipes nervosus Type II & & & & & & & & & & \\
\hline & Endochironomus sp. & & & & & & & & & & \\
\hline & Glyptotendipes & & & & & & & & & & \\
\hline & Harnischia sp. & & & 1. & & & & & & & \\
\hline & Microtendipes & & & & & & & & & 1 & \\
\hline & Nilothauma babiyi & & & & & & & & & & \\
\hline & Parachironomus abortivus & 1 & & & & & & & & & \\
\hline & Paracladopelma undine & & & & & & & & & & \\
\hline & Paralauterborniella nigrohalte & & & & & & & 1 & & & \\
\hline & Paratendipes albimanus & & & & & & & & & & \\
\hline & Paratendipes nudisquama & & & & & & & & & & \\
\hline & Phaenopsectra dyair & & & & & & & & & & \\
\hline & Phaenopsectra flavipes & & & & & & & & & & \\
\hline & Polypedilum convictum & & & 1 & & & & & & & \\
\hline & Polypedilum fallax & & & & & & & & & & \\
\hline & Polypedilum illinoense & & & & & & & & 1 & & \\
\hline & Polypedilum $\mathrm{nr}$. scaloenum & 2 & & 2. & 1 & 2. & 1 & 3. & & & \\
\hline & Pseudoch i ronomus sp. & & & & & & & & & & \\
\hline & Robackia sp. & & & & & & 2. & 2 & & 5 & \\
\hline & Stenochironomus sp. & & & & & & & & & & \\
\hline & Stictochironomus sp. & & & & & & & & & & \\
\hline & Tribelos sp. & 1. & & & & & & & & & \\
\hline & Xenochironomus sp. & & & & & & & & & & \\
\hline & Unidentified chironomini & & & & & & 2 & & & & \\
\hline
\end{tabular}




\begin{tabular}{|c|c|c|c|c|c|c|c|c|c|c|c|}
\hline TAXX & GENUS SPECIES & Rा2\1 & $R / 215$ & $R \backslash 216$ & $R \backslash 217$ & $R \backslash 2 \backslash 8$ & $R \backslash 4 \backslash 7$ & $R \backslash 412$ & $R \backslash 418$ & $814 \sqrt{9}$ & 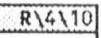 \\
\hline & Tanytarsini & & & & & & & & & & \\
\hline & Cladotanytarsus sp. & & 1 & 2 & 2 & 1 & & 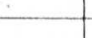 & & & \\
\hline & Lauterborniella & & & & & & & & & & \\
\hline & Micropsectra sp. & & & & & & & & & & \\
\hline & Rheotanytarsus sp. & 2 & 2 & 4 & 22 & 1 & & & & 1 & \\
\hline & Stempellinella sp & & & & & & & & & & \\
\hline & Tanytarsus coffmani & 1 & & & & & & & & & \\
\hline & Tanytarsus glabrescens & & & & & & & & & & \\
\hline & Tanytarsus querlus & 5 & & & 1 & & & & & & \\
\hline & Unidentified tanytarsini & & & & & & & & & & \\
\hline & Orthocladi inae & & & & & & & & & & \\
\hline & Brillia & & & & & & & & & & \\
\hline & Corynoneura celeripes & 9 & & 1 & 3 & & & & 1 & & \\
\hline & Corynoneura taris & 16 & & 1 & 11 & 3 & & & & & \\
\hline & Corynoneura sp & & & & & & & 1 & & & \\
\hline & Cricotopus bicinctus & & 1 & & 2 & 1 & & & & & \\
\hline & Cricotopus trifascia & & & & & & & & 2 & & \\
\hline & Cricotopus sp & & & & & & & & & & \\
\hline & Eukiefferiella sp. & & & & & & & & & & \\
\hline & Nanocladius crassicornus & 3. & & & & & & & & & \\
\hline & Nanocladius distinctus & & & & & & & & & & \\
\hline & Nanocladius rectinervis & & & & & & : & & & & \\
\hline & Nanocladius minimus & & & & & & & & & & \\
\hline & Nanocladius sp. & & & 1 & 1 & & & & & & \\
\hline & Parakiefferiella sp. & & & & & & & & & & \\
\hline & Rheocricotopus sp. & & & 4 & 1 & $\ldots$ & $\therefore$ & & & 1 & \\
\hline & Thienemanniella $\mathrm{nr}$. fusca & 3. & & 6 & 9 & 4. & & & & 1 & \\
\hline & Thienemanniella xena & 4 & & 15 & 17 & 4 & & 1 & & & \\
\hline & Unidentified orthocladinae & & & & & & 2. & 3 & & & \\
\hline & Tanypodinae & & & & & & & & & & \\
\hline & Ablabesmyia malloch $i$ & & & & & & & & & & \\
\hline & Ablabesmyia parajanta & 1 & & & & & & & & & \\
\hline & Ablabesmyia tarella & & & & & & & & & & \\
\hline & $\mathrm{Cl}$ inotanypus & & & & & & & & & & \\
\hline & Labrundinia pilosella & & & & & & & & & 1 & \\
\hline & Macropelopia sp. & & & & & & & & & & \\
\hline & Natarsia sp & & & & & & & & & & \\
\hline & Nilotanypus sp. & 5 & & 2 & 4 & 3. & & & & & \\
\hline & Pentaneura sp. & & & & & & & & & & \\
\hline & Procladius sp. & & & & & & & & & & \\
\hline & Thienemannimyia & & & & & & & & & & \\
\hline & Unidentified tanypodinae & 1 & & & & & & & & & \\
\hline & Diamesinae & & & & & & & & & & \\
\hline & Potthasia & & & & & & & & & & \\
\hline & Unidentified Chironomidae & 3 & 2. & 1 & 2. & 1. & 1 & 3. & 1. & 1 & \\
\hline & Ceratopogonidae & & & & & & & & & & \\
\hline & All uaudomyia sp. & & & & & & & & & & \\
\hline & Bezzia sp. & & & & & & & & & & \\
\hline & Unidentified ceratopogonid & & & & & & & & & & \\
\hline & Empididae & & & & & & & & & & \\
\hline & Hemerodromia & & & & & & & & & & \\
\hline & Tanyderidae & & & & & & 9 & & 3 & 3 & \\
\hline & Simul iidae & & & 4 & & 1 & & & & & \\
\hline & Simulium sp. & & & & 33 & & & & & & \\
\hline
\end{tabular}




\begin{tabular}{|c|c|c|c|c|c|c|c|c|c|c|c|}
\hline TAXA & GENUS SPECIES & R\2\1, & $R \backslash 2 \backslash 5$ & $R \backslash 216$ & $R \backslash 2 \backslash 7$ & $R \backslash 2 \backslash 8$ & $R \backslash 4 \backslash 1$ & 81412 & $8 1 4 \longdiv { 8 }$ & $R \backslash 4 \backslash 9$ & $R \backslash 4+10$ \\
\hline \multirow{2}{*}{\multicolumn{12}{|c|}{ EPHEMEROPIERA }} \\
\hline & & & & & & & & & & & \\
\hline & Baetisca sp & & & & & & & & & & \\
\hline & Caenis sp. & & & & & & & & & & \\
\hline & Ephemerella sp. & & & & & & & & & & \\
\hline & Isonychia & & & & 2. & 1. & & & & & \\
\hline$-\ldots$ & Tricorythodes sp. & & & & & & & & & & \\
\hline & Cinygmula subaequal is & & & & & & & & & & \\
\hline & Stenocron sp. & & & & & & & & & & \\
\hline & Stenonema sp. & 24. & & 7. & 6 & & & & & & \\
\hline & Spinadis wallace & & & 3 & 3. & & & & & & \\
\hline & Unknown sp. A (squatty bodies) & & & & & & & & & & \\
\hline & Unknown sp. B (slim guys) & & & & 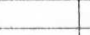 & & & & & & \\
\hline & Unknown sp. c & & & & & & & & & & \\
\hline & Unidentified & & & 1 & 4 & & & & & & \\
\hline & & & & & & & & & & & \\
\hline & Mesovelia & & & 1 & & & & & & & \\
\hline \multicolumn{12}{|l|}{ OOONATA } \\
\hline & Argia sp. & & & & & & & & & & \\
\hline & Macromia sp. & & & & & & & & & & \\
\hline & Archilestes & & & & & & & & & & \\
\hline & Dromogomphus sp. & & & & & & & & & & \\
\hline & Imnatures & & & & & & & & & & \\
\hline \multirow[t]{4}{*}{ PLECOPIERA } & & & & & & & & & & & \\
\hline & Perlinella ephyre & & & & & & & & & & \\
\hline & Imnatures & & & & & & & & & & \\
\hline & Unidentified & & & & & & 3. & 1 & 2. & 1. & 4 \\
\hline \multicolumn{12}{|l|}{ TRICHOPTERA } \\
\hline & Ceraclea & & & & & & & & & & \\
\hline & Macronema zebratum & & & & & & & & & & \\
\hline & Hydroptila sp. & & & & & & & & & & \\
\hline & Oecetis sp. & & & & 73. & & & & & 1 & \\
\hline & Chimarra sp. & 12 & & 19 & & 6 & & & & & \\
\hline & Polycentropus sp. & & & & 8. & & & & & & \\
\hline & Lype diversa & & & & & & & & & & \\
\hline & Unidentified & & & 2. & & & & & & 1 & \\
\hline \multicolumn{12}{|l|}{ AMPHIPOOA } \\
\hline & synurella sp. & & & & & & & & & & \\
\hline & Gammarus sp. & & & & & & & & & & 1 \\
\hline \multicolumn{12}{|l|}{ ISOPOOA } \\
\hline & Asellus sp. & & & & & & & $\therefore$ & & & \\
\hline ACARINA & & & & 5. & 7. & 1. & 3. & 1 & 1 & 1 & 2 \\
\hline \multicolumn{12}{|l|}{ MOLLUSCA } \\
\hline PELECYPODA & Corbicula fluminea & & & & & & & & & & \\
\hline \multirow[t]{4}{*}{ GASTROPODA } & Ferrissia rivularis & & & & & & & & & & \\
\hline & Amnicola sp. & & & & & & & & & & \\
\hline & Gyraulus sp. & & & & & & & & & & \\
\hline & Unidentified & & & & & & & & & & \\
\hline \multicolumn{12}{|l|}{ OTHER } \\
\hline NEMATOOA & & & 8. & 2. & & & 7. & 4. & 7. & 4 & 1 \\
\hline \multirow{2}{*}{\multicolumn{12}{|c|}{ NEMERTEA }} \\
\hline & & & & & & & & & & & \\
\hline & & 115 & 19 & 94 & 233 & 43 & 32 & 20 & 18 & 20 & 35 \\
\hline $\begin{array}{l}\text { OTAL NUMBER } \\
\text { NUMBER OF SPECT }\end{array}$ & & 24 & 8 & $2^{A}$ & 26 & 18 & 11 & 10 & 8 & 11 & 17 \\
\hline
\end{tabular}


APPENDIX E

COUNTS OF MAJOR TAXA, PER CORE SAMPLE, COLLECTED FROM SITE 4 IN THE FALL OF 1989 

Table E1. Counts of Major Taxa, per Core Sample, Collected From Site 4

in the Fall of 1989

\begin{tabular}{|c|c|c|c|c|c|c|c|c|c|c|}
\hline \multirow[b]{2}{*}{ Major Taxa } & \multicolumn{5}{|c|}{ Pool Samples } & \multicolumn{5}{|c|}{ Riffle Samples } \\
\hline & 1 & 3 & 4 & 6 & 9 & 2 & 3 & 5 & 7 & 9 \\
\hline Oligochaeta & 1 & 4 & 1 & 3 & & & 1 & 1 & & \\
\hline Chironomidae & 15 & 59 & 78 & 100 & 42 & 30 & 19 & 18 & 21 & 13 \\
\hline Ceratopogonidae & & & & 1 & 3 & & & & & \\
\hline Coleoptera & & & & & & & & & 1 & 1 \\
\hline Ephemeroptera & & 1 & & & & & & & & \\
\hline Acarina & & & & & 2 & 1 & & & & \\
\hline Nematoda & 2 & . & 2 & 2 & 1 & & & & & \\
\hline Nemertea & & & & & 2 & & & & & \\
\hline
\end{tabular}

Table E2. Species Composition of 01igochaetes and Chironomids

Collected From Site 4 in Fall 1989

\begin{tabular}{|c|c|c|c|c|c|c|c|c|c|c|}
\hline & & Po & & & & & 2if & e $\mathrm{S}$ & $\overline{\mathrm{ple}}$ & \\
\hline Taxa & 1 & 3 & 4 & 6 & 9 & 2 & 3 & $\underline{5}$ & 7 & 9 \\
\hline $\begin{array}{l}\text { Oligochaeta } \\
\text { Naididae }\end{array}$ & & & & & & & & & & \\
\hline Dero furcata & & 1 & & 2 & & & & & & \\
\hline Pristina leidyi & & & & & & & & 1 & & \\
\hline $\begin{array}{l}\text { Specaria josinae } \\
\text { Tubificidae }\end{array}$ & & 2 & & & & & & & & \\
\hline Unidentified & & & 1 & & & & 1 & & & \\
\hline $\begin{array}{l}\text { Chironomidae } \\
\text { Chironominae }\end{array}$ & & & " & & & & & & & \\
\hline Chironomus sp. & & & 1 & & & & & & & \\
\hline $\begin{array}{l}\text { Dicrotendipes nervosus II } \\
\text { Harnischia sp. }\end{array}$ & & & 1 & & & & & & & \\
\hline Phaenopsectra dyari & 3 & 27 & 38 & 33 & 17 & & & & & \\
\hline Phaenopsectra flavipes & 1 & 5 & 10 & 3 & 6 & & & & & \\
\hline Polypedilum fallax & & & 1 & & & & & & & \\
\hline Polypedilum illinoense & & 1 & & & 1 & & & & & \\
\hline Polypedilum nr. scaloneum & 11 & 4 & 20 & 8 & 7 & 8 & 8 & 4 & 6 & 7 \\
\hline $\begin{array}{l}\text { Robackia sp. } \\
\text { Tanytarsini }\end{array}$ & & & & & & 21 & 9 & 12 & 14 & 6 \\
\hline Tanytarsus querlus & & & 2 & 2 & 1 & & & & & \\
\hline Tanypodinae & & & & & & & & & & \\
\hline Ablabesmyia parajanta & & 5 & & 1 & 3 & & & & & \\
\hline $\begin{array}{l}\text { Procladius sp. } \\
\text { Orthocladinae }\end{array}$ & & & 1 & & & & & & & \\
\hline Coryoneura celeripes & & & & & & & 1 & & 1 & 1 \\
\hline Coryoneura taris & & & & & & 1 & & & 1 & 1 \\
\hline Thienemannimyia sp. & & & 1 & & & & & & & \\
\hline Thienemanniella $\mathrm{nr}$. fusca & & & & & 1 & & & & & \\
\hline
\end{tabular}


